U.S. Department of the Interior

U.S. Geological Survey

Prepared in cooperation with

Idaho Department of Environmental Quality

\title{
A Statistical Model for Estimating Stream Temperatures in the Salmon and Clearwater River Basins, Central Idaho
}

Water-Resources Investigations Report 02-4195 


\section{A Statistical Model for Estimating Stream Temperatures in the Salmon and Clearwater River Basins, Central Idaho}

By Mary M. Donato

Water-Resources Investigations Report 02-4195

Prepared in cooperation with

Idaho Department of Environmental Quality

Boise, Idaho

2002 


\section{U.S. DEPARTMENT OF THE INTERIOR}

GALE A. NORTON, Secretary

\section{U.S. GEOLOGICAL SURVEY}

Charles G. Groat, Director

Any use of firm, trade, and brand names in this report is for identification purposes only and does not constitute endorsement by the U.S. Government.

Additional information can be obtained from:

District Chief

U.S. Geological Survey 230 Collins Road

Boise, ID 83702-4520

http://idaho.usgs.gov
Copies of this report can be purchased from:

U.S. Geological Survey

Information Services

Box 25286

Federal Center

Denver, CO 80225

e-mail: infoservices@usgs.gov
Copies of this report also are available in PDF format, which can be viewed using Adobe Acrobat Reader, at URL:

http://idaho.usgs.gov/public/reports.html 


\section{CONTENTS}

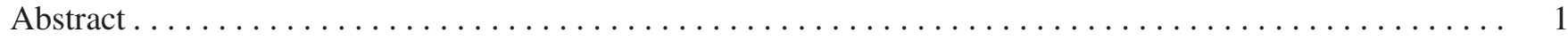

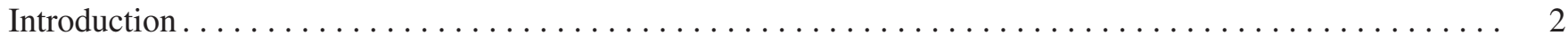

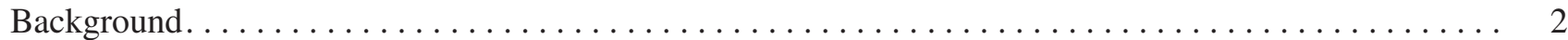

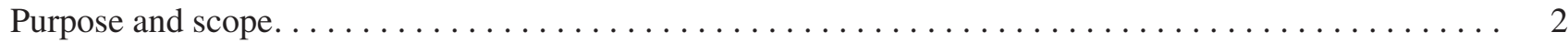

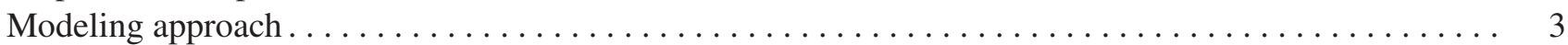

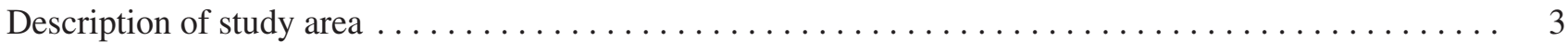

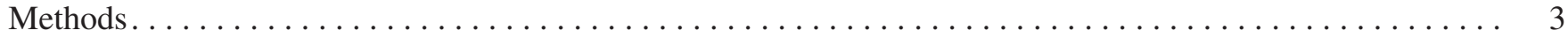

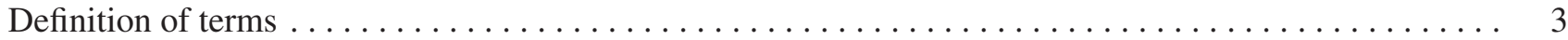

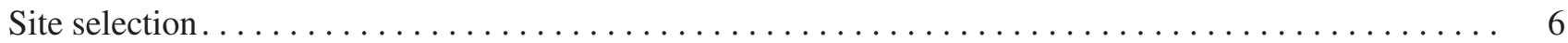

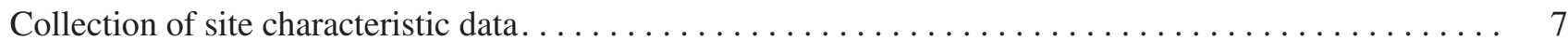

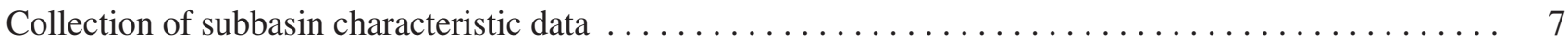

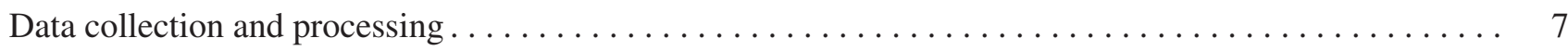

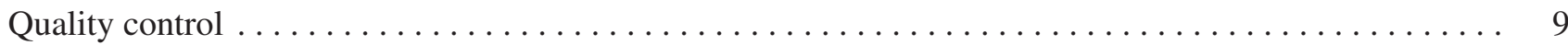

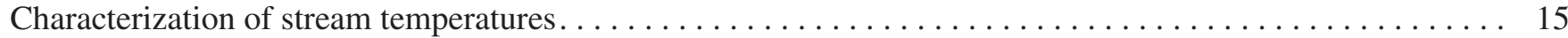

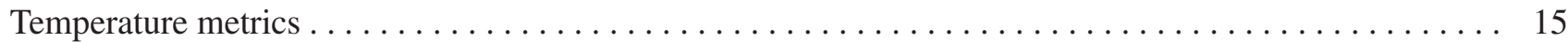

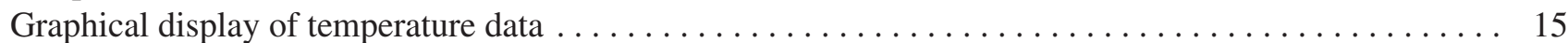

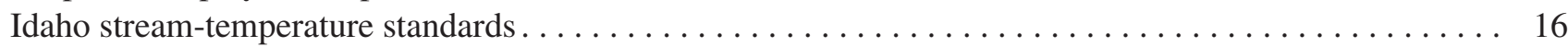

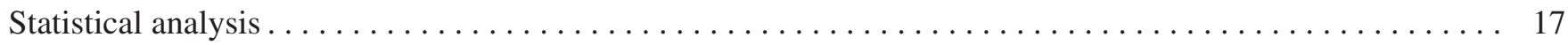

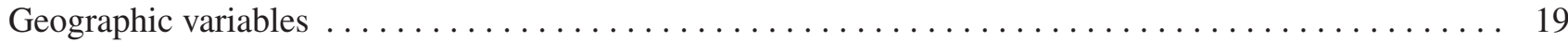

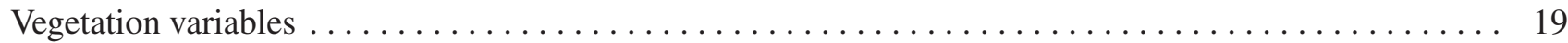

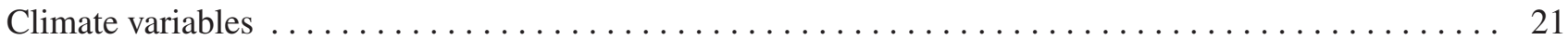

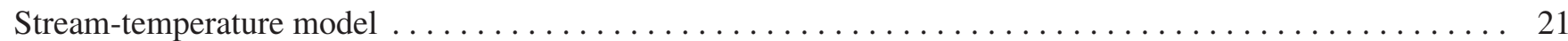

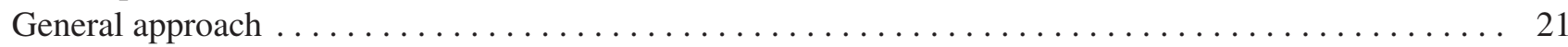

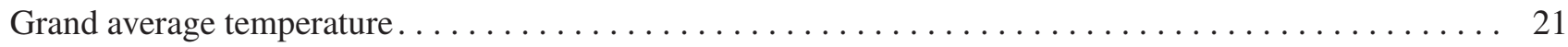

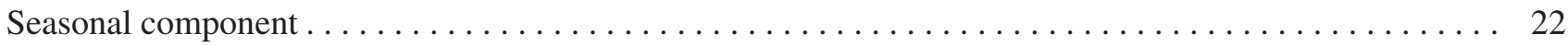

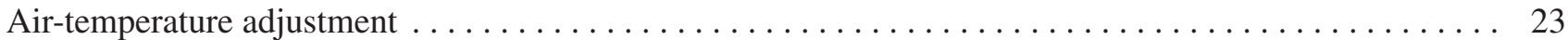

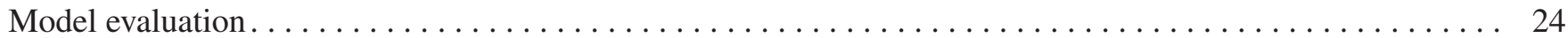

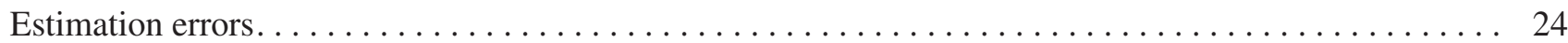

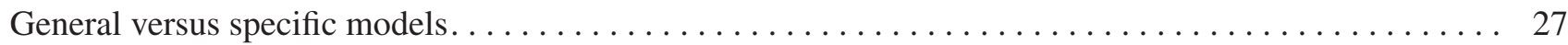

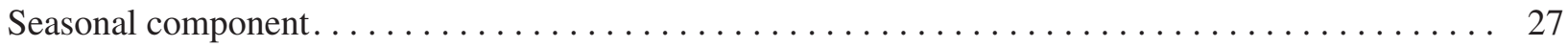

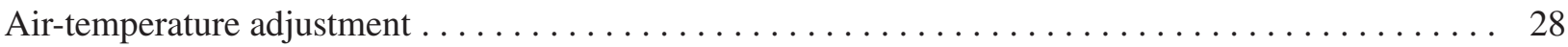

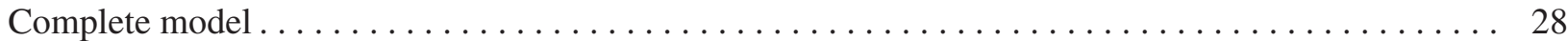

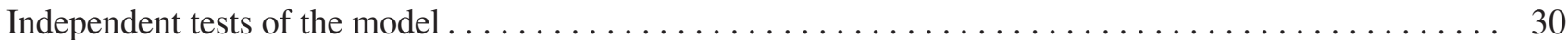

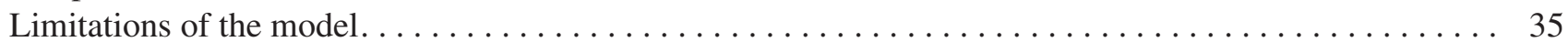

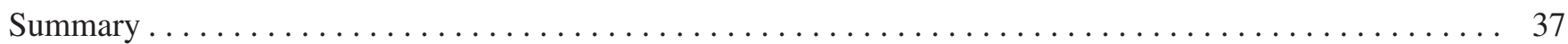

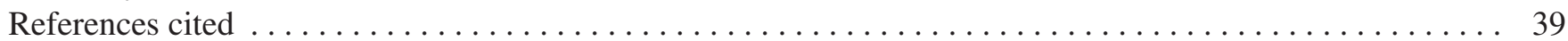

\section{FIGURES}

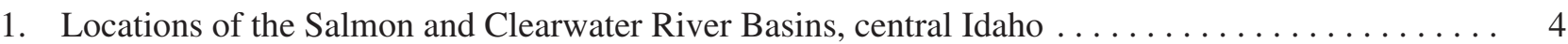

2. Monitored sites that provided stream-temperature data used to develop and test the statistical model, Salmon and Clearwater River Basins, central Idaho. . . . . . . . . . . . . . . . . 8

3. Daily average temperature for representative streams in the Salmon and Clearwater River Basins, central Idaho . . . . . . . . . . . . . . . . . . . . . . . . . . . . . . . . . . . . 14

4. Hourly temperature for streams with contrasting diurnal temperature fluctuation in the

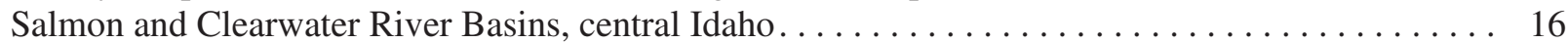


5. Quantile diagram for selected streams in the Salmon and Clearwater River Basins, central Idaho . . . . . . . . . . . . . . . . . . . . . . . . . . . . . . . . . . 17

6. Exceedance curves for representative streams in the Salmon and Clearwater River Basins,

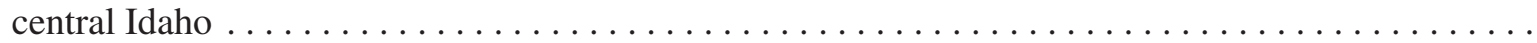

7. Sites where stream temperatures met or exceeded current Idaho stream-temperature standards for cold-water biota during the 2000 monitoring period, Salmon and Clearwater

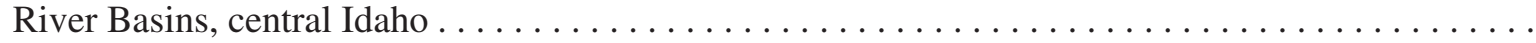

8. Deviation from grand average temperature for representative streams in the Salmon and Clearwater River Basins, central Idaho. . . . . . . . . . . . . . . . . . . . . . .

9. Locations of weather stations that provided air-temperature data used to derive the airtemperature adjustment component of the statistical model, Salmon and Clearwater River Basins, central Idaho . . . . . . . . . . . . . . . . . . . . . . . . . . . . . . . . .

10.-20. Graphs showing:

10. Mean daily stream-temperature error and 95-percent confidence interval for all sites used to develop the statistical model, Salmon and Clearwater River Basins, central Idaho. . . . . . . . . . . . . . . . . . . . . . . . . . .

11. Mean daily stream-temperature error for all sites used to develop the statistical model, calculated by stream-order group, Salmon and Clearwater River Basins, central Idaho. . . . . . .

12. Periodic functions of deviation from grand average temperature for the general model and for three specific models based on stream-order groups, Salmon and Clearwater River Basins, central Idaho . . . . . . . . . . . . . . . . . . . . . . . . .

13. Errors in seasonal component of the general model and three specific models based on stream-order groups, Salmon and Clearwater River Basins, central Idaho . . . . . . . . . . . . .

14. Daily average air-temperature adjustments calculated by the general model and three specific models based on stream-order groups, Salmon and Clearwater River Basins, central Idaho. . . . . . . . . . . . . . . . . . . . . . . . . . . .

15. Mean estimation errors for the general model and for three specific models, Salmon and Clearwater River Basins, central Idaho. ...........................

16. Estimated and observed temperatures of the Salmon River above Redfish Lake Creek, 1980 and 1982, Salmon River Basin, central Idaho. . . . . . . . . . . . . . . . . . . .

17. Estimated and observed temperatures of the Red River below South Fork near Red River Ranger Station, 1984 and 1986, Clearwater River Basin, central Idaho . . . . . . . . . . . . . .

18. Estimated and observed temperatures of Big Deer Creek, 1999 and 2000, Salmon River Basin, central Idaho . . . . . . . . . . . . . . . . . . . . . . .

19. Estimated and observed temperatures of the Lochsa River above Wilderness Gateway Campground, 1998, Clearwater River Basin, central Idaho . . . . . . . . . . . . . . . .

20. Estimated and observed temperatures of Wilson Creek, 2001, Salmon River Basin, central Idaho.

\section{TABLES}

1. Definitions of subbasin and site characteristics and stream-temperature metrics used in the statistical model and methods used in their derivation or calculation, Salmon and Clearwater River Basins, central Idaho . . . . . . . . . . . . . . . . . . . . . . . . .

2. Statistical summary of selected subbasin and site characteristics for monitored sites used in the statistical model, Salmon and Clearwater River Basins, central Idaho . . . . . . . . . . . . .

3. Selected stream-temperature metrics for monitored sites used in the statistical model,

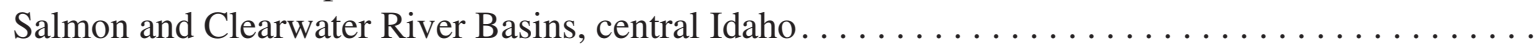


4. Statistical summary, grouped by stream order, of selected stream-temperature metrics for monitored sites used in the statistical model, Salmon and Clearwater River Basins,

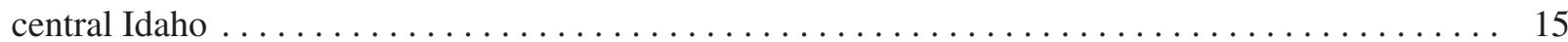

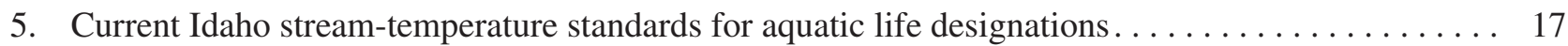

6. Spearman correlation coefficients describing correlation of subbasin or site characteristics with stream-temperature metrics for 183 monitored sites used in the statistical model,

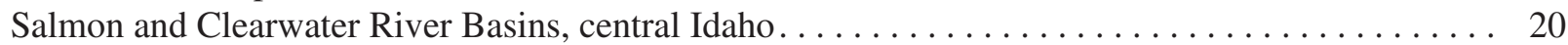

7. Results of multiple linear regression to estimate grand average temperature for 183 monitored sites used in the statistical model, Salmon and Clearwater River Basins, central Idaho . . . . . . . 22

8. Results of simple linear regression for the air-temperature adjustment component of the statistical model, Salmon and Clearwater River Basins, central Idaho. . . . . . . . . . . . . . . 24

9. Ratio of mean August discharge to long-term average August discharge at selected streamgaging stations for the year 2000 and for years for which the model was tested, Salmon and Clearwater River Basins, central Idaho. . . . . . . . . . . . . . . . . . . . . . . . . . . . 32

\section{CONVERSION FACTORS AND VERTICAL DATUM}

\begin{tabular}{rll}
\hline Multiply & By & To obtain \\
\hline meter $(\mathrm{m})$ & 3.281 & foot \\
kilometer $(\mathrm{km})$ & 0.6214 & mile \\
square kilometer $\left(\mathrm{km}^{2}\right)$ & 0.3861 & square mile \\
\hline
\end{tabular}

Temperature in degrees Celsius $\left({ }^{\circ} \mathrm{C}\right)$ can be converted to degrees Fahrenheit $\left({ }^{\circ} \mathrm{F}\right)$ as follows:

$$
{ }^{\circ} \mathrm{F}=(1.8)\left({ }^{\circ} \mathrm{C}\right)+32
$$

Sea level: In this report, "sea level" refers to the National Geodetic Vertical Datum of 1929-a geodetic datum derived from a general adjustment of the first-order level nets of the United States and Canada, formerly called Sea Level Datum of 1929. 


\section{A Statistical Model for Estimating Stream Temperatures in the Salmon and Clearwater River Basins, Central Idaho}

By Mary M. Donato

\section{Abstract}

A water-quality standard for temperature is critical for the protection of threatened and endangered salmonids, which need cold, clean water to sustain life. The Idaho Department of Environmental Quality has established temperature standards to protect salmonids, yet little is known about the normal range of temperatures of most Idaho streams. A single temperature standard for all streams does not take into account the natural temperature variation of streams or the existence of naturally warm waters. To address these issues and to help the Idaho Department of Environmental Quality revise the existing State temperature standards for aquatic life, temperature data from more than 200 streams and rivers in the Salmon and Clearwater River Basins were collected. From these data, a statistical model was developed for estimating stream temperatures on the basis of subbasin and site characteristics and climatic factors.

Stream temperatures were monitored hourly for approximately 58 days during July, August, and September 2000 at relatively undisturbed sites in subbasins in the Salmon and Clearwater River Basins in central Idaho. The monitored subbasins vary widely in size, elevation, drainage area, vegetation cover, and other characteristics. The resulting data were analyzed for statistical correlations with subbasin and site characteristics to establish the most important factors affecting stream temperature. Maximum daily average stream temperatures were strongly correlated with elevation and total upstream drainage area; weaker correlations were noted with stream depth and width and average subbasin slope. Stream temperatures also were correlated with certain types of vegetation cover, but these variables were not significant in the final model.

The model takes into account seasonal temperature fluctuations, site elevation, total drainage area, average subbasin slope, and the deviation of daily average air temperature from a 30-year normal daily average air temperature. The goodnessof-fit of the model varies with day of the year. Overall, temperatures can be estimated with 95percent confidence to within approximately plus or minus 4 degrees Celsius. The model performed well when tested on independent stream-temperature data previously collected by the U.S. Geological Survey and other agencies.

Although the model provides insight into the natural temperature potential of a wide variety of streams and rivers in the Salmon and Clearwater River Basins, it has limitations. It is based on data collected in only one summer, during which temperatures were higher and streamflows were lower than normal. The effects of changes in streamflow on the effectiveness of the model are not known. Because the model is based on data from minimally disturbed or undisturbed streams, it should not be applied to streams known to be significantly affected by human activities such as disturbance of the streambed, diversion and return of water by irrigation ditches, and removal of riparian vegetation. Finally, because the model is based on data from streams in the Salmon and Clearwater River Basins and reflects climatological and landscape characteristics of those basins, it should not be applied to streams outside this region. 


\section{INTRODUCTION}

\section{Background}

Stream temperature is a critical element of water quality because it directly and indirectly influences the biological communities, particularly fish and benthic invertebrates, that inhabit the stream. Salmonids (salmon, trout, and charr) are particularly sensitive to stream temperature, which affects their metabolism, growth rates, food requirements, and the timing of lifehistory events such as migration and smoltification. Temperature also plays an important role in the occurrence of diseases and parasites. Dissolved oxygen content, biochemical oxygen demand rates, algae production, and contaminant toxicity are all strongly related to temperature.

Stream temperatures vary temporally (with the seasons and over the course of 24 hours) and spatially (over the length of a stream). Although stream temperatures have never been optimal in all places and at all times in the Pacific Northwest, salmonids have developed physiological and behavioral adaptations that have allowed them to thrive in this region. In many streams, natural cold-water refugia (protected areas) have played a critical role in the evolution of many salmonids. Fish have survived less-than-optimal temperatures by resting and cooling off in refugia during migration. However, human activities have played a role in changing the thermal regime of streams, thus contributing, directly and indirectly, to the decline in native salmonid populations.

Water temperature is the most common waterquality violation in the Pacific Northwest. According to the Clean Water Act, the numerous violations must be addressed by Total Maximum Daily Load plans. As part of the overall plan for Idaho, the Idaho Department of Environmental Quality (DEQ) has developed stream-temperature standards to protect cold-water fauna, including the bull trout. It is recognized, however, that a single temperature standard for all streams may not accommodate the natural temperature variation within and among streams or the existence of naturally warm waters. For example, recent data suggest that streams unaffected or minimally affected by human impact may naturally exceed current temperature standards. Some streams known to exceed current temperature standards for bull trout appear to support popula- tions of these cold-water fauna (Essig, 1998). To establish realistic and enforceable temperature standards, we must understand the natural temperature potential and limitations of streams. Because it is unfeasible to simulate natural stream temperatures in every drainage basin in Idaho, agencies would benefit from a practical method to estimate natural stream temperatures on the basis of basin characteristics and other readily available data. A statistical model was developed to help fill this need.

\section{Purpose and Scope}

This report describes the results of an investigation for which the objectives were to 1) characterize stream temperatures over a large region in a variety of settings in the Salmon and Clearwater River Basins in central Idaho and 2) develop a statistical model to estimate stream temperatures in subbasins where temperatures are not known or previously have not been monitored. The U.S. Geological Survey (USGS), with assistance from DEQ, used digital temperature loggers to collect hourly stream-temperature data at sites in more than 200 subbasins in the Salmon and Clearwater River Basins over an approximately 2-month period during the summer of 2000. Site characteristics such as vegetation cover, channel width, and channel orientation also were collected. Various stream-temperature metrics, or measures (for example, maximum weekly average temperature), were calculated, and statistical correlations between the metrics and site and subbasin characteristics and climatological data were identified. On the basis of these correlations, an expression was developed for estimating daily average stream temperatures for the interval July 24 to September 10. Because this study is restricted to the Salmon and Clearwater River Basins of Idaho, the model results are applicable only to streams in this region of central Idaho.

An important aspect of establishing stream temperature standards to protect aquatic life is characterizing the biological communities and understanding their relationship to stream temperature and to habitat variables such as vegetation and channel characteristics. To address these issues and to provide DEQ with biological information, the USGS in 2001 began a detailed biological study of carefully selected reference sites in the Salmon River Basin. 


\section{Modeling Approach}

Stream temperature as a general topic has been widely studied, and the physics of heat transfer is one of the better understood processes in natural watershed systems (Sullivan and others, 1990). Heat-transfer processes involved in controlling stream temperatures include solar radiation, long-wave radiative exchange with sky and vegetation, convection with air, evaporation, conduction to and from the soil and air, and advection from incoming water sources, including ground water.

There are two basic approaches to stream-temperature modeling, both of which use the same principles of heat transfer. The first approach, used by many researchers, is an energy-balance method based on the physical processes of heat transfer (Bartholow, 1989). Mechanistic models based on this approach are essentially sophisticated energy accounting systems that keep track of heat input and outflow to describe and predict changes in stream temperature. The models first are calibrated to existing conditions for a stream reach using measured data. Natural stream temperatures then are simulated after adjusting the shade and hydraulic parameters in the model. Unfortunately, this approach is costly and time consuming. Another approach, which is less costly but still requires measured temperature data, is to use observed statistical relationships between stream temperature and landscape, climate, vegetation, and stream-channel characteristics to develop statistical models to predict stream temperatures (Wehrly and others, 1997). The method used in this study is more closely related to the second approach.

Temperature data were collected from streams in the Salmon and Clearwater River Basins of central Idaho to examine the natural spatial and temporal variability of water temperatures and to create a data base for developing a statistical model. Subbasins in the Salmon and Clearwater River Basins previously were delineated as part of a study by Lipscomb (1998). A data base of characteristics, including physiographic, hydrologic, climatologic, geologic, and land-cover data for each subbasin, also was developed in that study. These 1,031 subbasins and their associated characteristics provided the framework of this investigation.

Stream temperatures were monitored at fixed 1hour intervals from approximately July 15 through
September 30, 2000, at more than 200 carefully selected sites in a variety of environments. The temperature data then were statistically analyzed to determine the most important environmental factors related to stream temperatures. The strongest statistical correlations were used to develop a model that estimates daily average stream temperatures for July 24 to September 10 in subbasins where there is no a priori knowledge of temperature.

\section{Description of Study Area}

The Salmon and Clearwater River Basins encompass approximately $60,770 \mathrm{~km}^{2}$ in central Idaho (fig. 1). The region includes extensive areas of minimal human impact and a variety of stream sizes in an assortment of hydrologic and geographic settings. It includes parts of seven national forests, five designated wild and scenic rivers, and four wilderness areas, the latter composing about 25 percent of the study area (Lipscomb, 1998).

The headwaters of the Salmon River are in the Sawtooth Range of central Idaho. Principal tributaries are the Pahsimeroi, Lemhi, and East Fork, North Fork, South Fork, and Middle Fork Salmon, and Little Salmon Rivers. The headwaters of the Clearwater River are in the Bitterroot Mountains near the IdahoMontana State line. Principal tributaries are the North Fork, South Fork, and Middle Fork Clearwater Rivers and the Lochsa and Selway Rivers.

The study area includes the highest and lowest points in Idaho. Borah Peak, near the headwaters of the Pahsimeroi River, is at an elevation of $3,859 \mathrm{~m}$ above sea level, whereas Lewiston, at the confluence of the Clearwater and Snake Rivers, is at an elevation of $225 \mathrm{~m}$. Total relief in the study area is more than $3 \mathrm{~km}$ (Lipscomb, 1998).

\section{METHODS}

\section{Definition of Terms}

Subbasin and site characteristics and temperature metrics were given abbreviated names to simplify referencing in the report. Definitions of these abbreviations and methods of derivation or calculation are given in table 1. 


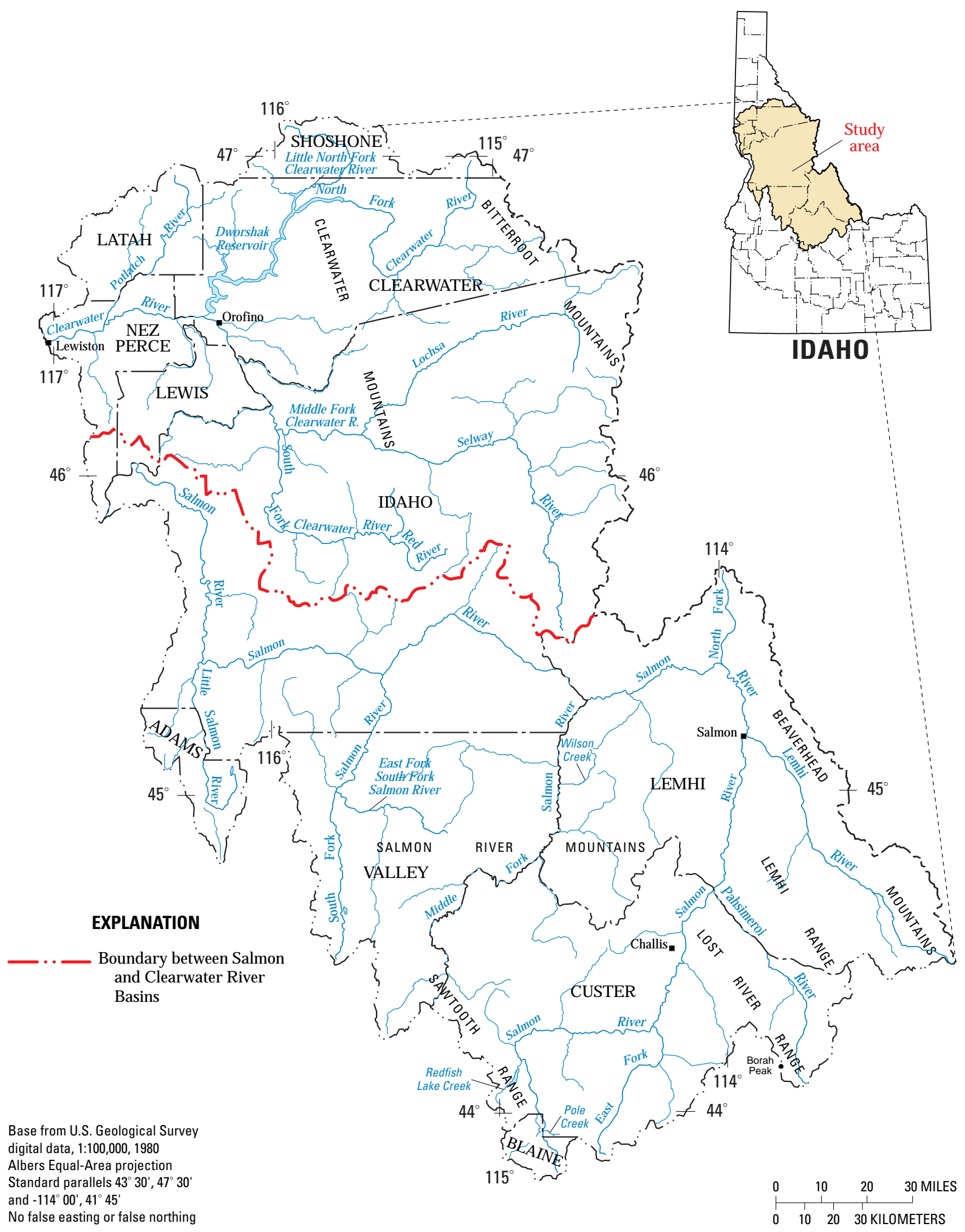

Figure 1. Locations of the Salmon and Clearwater River Basins, central Idaho. 
Table 1. Definitions of subbasin and site characteristics and stream-temperature metrics used in the statistical model and methods used in their derivation or calculation, Salmon and Clearwater River Basins, central Idaho

[All stream-temperature metrics are in ${ }^{\circ} \mathrm{C}$, degrees Celsius; $\mathrm{km}^{2}$, square kilometers; GIS98, derived by Lipscomb (1998) from a digital elevation model using a geographic information system; m, meters; GIS/NLCD, derived from a National Land Cover Data coverage using a geographic information system; PT, percentage of total subbasin area; ft, feet]

\begin{tabular}{|c|c|c|}
\hline Characteristic or metric & Definition & Method of derivation or calculation \\
\hline \multicolumn{3}{|c|}{ Subbasin characteristics } \\
\hline DRAINAREA & $\begin{array}{l}\text { Sum of all upstream subbasin } \\
\text { areas, in } \mathrm{km}^{2}\end{array}$ & GIS98 \\
\hline MSLOPE & Average subbasin slope, in percent & GIS98 \\
\hline SOUTH & Subbasin area facing south, as PT & GIS98 \\
\hline SWEST & $\begin{array}{l}\text { Subbasin area facing southwest, as } \\
\text { PT }\end{array}$ & GIS98 \\
\hline SUMSSW & $\begin{array}{l}\text { Sum of subbasin areas facing south } \\
\text { and southwest, as PT }\end{array}$ & GIS98 \\
\hline \multicolumn{3}{|c|}{$\begin{array}{l}\text { Site characteristics } \\
\end{array}$} \\
\hline SITEELEV & Site elevation, in $\mathrm{m}$ above sea level & Measured in field or determined from map \\
\hline MEANELEV & $\begin{array}{l}\text { Average subbasin elevation, in } \mathrm{m} \\
\text { above sea level }\end{array}$ & GIS98 \\
\hline AREASQKM & Subbasin area, in $\mathrm{km}^{2}$ & GIS98 \\
\hline AZIMUTH & $\begin{array}{l}\text { Downstream-facing direction, in } \\
\text { degrees }\end{array}$ & Measured in field \\
\hline SEGAZIMUTH & $\begin{array}{l}\text { Stream segment azimuth, in } \\
\text { degrees }\end{array}$ & $\begin{array}{l}\text { Derived using geographic information system and method of Bar- } \\
\text { tholow (1989) }\end{array}$ \\
\hline FOREST & Forest of all types, as PT & GIS/NLCD \\
\hline DECIDFOR & Deciduous forest, as PT & GIS/NLCD \\
\hline EVERGRFOR & Evergreen forest, as PT & GIS/NLCD \\
\hline WETLAND & Wetland, as PT & GIS/NLCD \\
\hline EMERGWET & Emergent wetland, as PT & GIS/NLCD \\
\hline BARREN & Barren land, as PT & GIS/NLCD \\
\hline GRASS & Grassland, as PT & GIS/NLCD \\
\hline OPENCAN & Open canopy angle, in degrees & Measured in field using clinometer \\
\hline $\mathrm{RCC}$ & Riparian canopy cover, in percent & Measured in field using densiometer \\
\hline AUGTEMPC & Mean August air temperature, in ${ }^{\circ} \mathrm{C}$ & $\begin{array}{l}\text { Derived using geographic information system from coverage based on } \\
\text { PRISM climate model and downloaded April 16, 2001, at } \\
\text { http://www.climatesource.com/ }\end{array}$ \\
\hline WIDTHFT & Mean stream width, in $\mathrm{ft}$ & Measured in field \\
\hline MDEPTHFT & Mean stream depth, in $\mathrm{ft}$ & Measured in field \\
\hline \multicolumn{3}{|c|}{$\begin{array}{l}\text { Stream-temperature metrics } \\
\end{array}$} \\
\hline MDMT & $\begin{array}{l}\text { Maximum daily maximum temper- } \\
\text { ature }\end{array}$ & $\begin{array}{l}\text { Highest of all measured temperatures. Equivalent to instantaneous } \\
\text { maximum temperature or grand maximum temperature }\end{array}$ \\
\hline MDAT & $\begin{array}{l}\text { Maximum daily average tempera- } \\
\text { ture }\end{array}$ & Highest of all daily mean temperatures \\
\hline MDNT & $\begin{array}{l}\text { Maximum daily minimum temper- } \\
\text { ature }\end{array}$ & Highest of all daily minimum temperatures \\
\hline MWMT & $\begin{array}{l}\text { Maximum weekly maximum tem- } \\
\text { perature }\end{array}$ & $\begin{array}{l}\text { Starting with the } 7^{\text {th }} \text { day of monitoring, the mean of the daily maxi- } \\
\text { mum temperatures for days } 1 \text { though } 7 \text { was computed. This proce- } \\
\text { dure was repeated for days } 2 \text { though } 8,3 \text { through } 9 \text {, etc. The MWMT } \\
\text { is the highest mean value obtained for the monitoring period }\end{array}$ \\
\hline MWAT & $\begin{array}{l}\text { Maximum weekly average temper- } \\
\text { ature }\end{array}$ & $\begin{array}{l}\text { Starting with the } 7^{\text {th }} \text { day of monitoring, the mean of the daily average } \\
\text { temperatures for days } 1 \text { though } 7 \text { was computed. This procedure was } \\
\text { repeated for days } 2 \text { though } 8,3 \text { through } 9 \text {, etc. The MWAT is the } \\
\text { highest mean value obtained for the monitoring period }\end{array}$ \\
\hline
\end{tabular}


Table 1. Definitions of subbasin and site characteristics and stream-temperature metrics used in the statistical model and methods used in their derivation or calculation, Salmon and Clearwater River Basins, central Idaho-Continued

\begin{tabular}{|c|c|c|}
\hline Characteristic or metric & Definition & Method of derivation or calculation \\
\hline \multicolumn{3}{|c|}{ Stream-temperature metrics-Continued } \\
\hline $\mathrm{MAX} \Delta \mathrm{T}$ & Maximum diurnal variation & Daily maximum temperature minus daily minimum temperature \\
\hline $\mathrm{BIG} \Delta \mathrm{T}$ & $\begin{array}{l}\text { Total temperature variation during } \\
\text { entire monitoring period }\end{array}$ & Highest recorded temperature minus lowest recorded temperature \\
\hline GAT & Grand average temperature & Average of all temperature measurements \\
\hline Percent $>13^{\circ} \mathrm{C}$ & $\begin{array}{l}\text { Percent of monitoring period tem- } \\
\text { peratures exceeded } 13^{\circ} \mathrm{C}\end{array}$ & $100 \mathrm{x}$ Number of hourly readings over $13^{\circ} \mathrm{C}$ divided by 1,392 \\
\hline Percent $>22^{\circ} \mathrm{C}$ & $\begin{array}{l}\text { Percent of monitoring period tem- } \\
\text { peratures exceeded } 22^{\circ} \mathrm{C}\end{array}$ & $100 \mathrm{x}$ Number of hourly readings over $22^{\circ} \mathrm{C}$ divided by 1,392 \\
\hline CONSEC13 & $\begin{array}{l}\text { Maximum number of consecutive } \\
\text { hours temperature exceeded } \\
13^{\circ} \mathrm{C}\end{array}$ & \\
\hline CONSEC22 & $\begin{array}{l}\text { Maximum number of consecutive } \\
\text { hours temperature exceeded } \\
22^{\circ} \mathrm{C}\end{array}$ & \\
\hline
\end{tabular}

\section{Site Selection}

Goals of site selection were to choose 1) sites in a large number of subbasins that represent a variety of total drainage area, elevation, vegetation cover, geology, and topography; 2) sites without significant human disturbance such as placer mining, heavy vegetation removal, and dams so that the most natural temperature conditions in and around the streams could be recorded; and 3) sites that were well distributed throughout the region. Lipscomb (1998) delineated 1,031 hydrologic subbasins in the Salmon and Clearwater River Basins, and these subbasins comprised the candidates for site selection for this study. First, subbasins were grouped according to stream orders assigned by Lipscomb (1998). Next, commercial statistical software was used to cluster the subbasins in each group on the basis of similarities in total drainage area, average elevation, and percent forest cover. Finally, subbasins were selected randomly from each of the resulting clusters, and monitoring sites were located in these subbasins.

Statistical software offers several different methods of cluster analysis and allows the user to decide on the final number of clusters. Divisive, hierarchical clustering into a total of eight clusters was used because this method discriminated well between the Salmon and Clearwater River Basins (facilitating geographic distribution of subbasins) and differentiated between subbasins containing higher order and lower order streams. A total of 868 subbasins containing first-, second-, and third-order streams were grouped in 6 clusters; a total of 163 subbasins containing fourth- and fifth-order streams were grouped in 2 clusters. The Strahler stream-order convention, based on 1:100,000 hydrography, later was adopted for this study because it is used by DEQ. In most cases, the effect of reassigning stream order on the basis of this convention was to raise the stream order by one unit (for example, firstorder streams became second-order streams). This affected the way the subbasins were grouped but did not affect the interpretation of the results. The 8 clusters ranged in size from 19 to 268 subbasins.

Subbasins were selected randomly from each of the eight clusters. The initial goal was to select 200 subbasins and then locate one site in each. The number of subbasins selected from each cluster was based on the proportion of cluster members to the total number of subbasins. Several extra subbasins in each cluster were selected as backups to be used if no suitable site within a subbasin was found in the field. Because many of these extra subbasins also contained suitable sites, the number of sites included in the study was increased to 228. Subbasins were selected randomly by consecutively numbering the subbasins within each cluster, shuffling each list of subbasins using a built-in random selection routine in a spreadsheet, and selecting from the shuffled list in order from top to bottom. Because of 
budget and time constraints, each subbasin was evaluated using topographic maps to assure that it was accessible by road. If a subbasin was determined to be inaccessible by road or likely to be markedly disturbed by human activities, it was deleted and the next subbasin on the list was considered. This procedure continued until the required number of subbasins in each cluster was selected. Finally, one site within the lower one-third of each subbasin was targeted on a topographic map. Field crews deployed temperature loggers as close as possible to the target site. A total of 236 temperature loggers were deployed at 228 sites.

Because many large areas in central Idaho are not accessible by road, some subbasins, including parts of the Middle Fork of the Salmon River and its tributaries, were impossible to monitor during this phase of the project. However, adequate and well distributed coverage of most of the study area was achieved (fig. 2). Additional sites monitored in 2001 as part of the biological component of the project could provide temperature data for the omitted subbasins, but those data were not available for this study.

\section{Collection of Site Characteristic Data}

A variety of site-specific data were recorded on a standardized data sheet by field crews at the time the temperature loggers were deployed. Ten equally spaced measurements of temperature, depth, and specific conductance were made across the stream to assure that the water at the site was well mixed. General stream habitat (riffle, pool, or run) and stream azimuth (downstream-facing direction) were noted. Air-temperature and elevation data were recorded; some measurements were repeated at the time the loggers were retrieved. Photographs were taken at most sites. Vegetation cover was described in two ways: open canopy angle (OPENCAN) and riparian canopy cover (RCC). OPENCAN was measured at midstream using a clinometer (Fitzpatrick and others, 1998). RCC (in percent) was determined from the banks using a spherical densiometer (Fitzpatrick and others, 1998). Because of time and budgetary constraints, only one measurement of each of these parameters was made at each site. Several measurements along a reach might have given a better representation of the vegetation cover. The latitude and longitude of the site were determined using a global positioning system receiver.

\section{Collection of Subbasin Characteristic Data}

Many subbasin characteristics, including geographic information system (GIS)-derived parameters, previously had been compiled by Lipscomb (1998). These included total drainage area, average subbasin slope, aspect (slope facing directions), average subbasin elevation, subbasin area, and percent forest cover. Several other subbasin characteristics were derived or obtained as GIS coverages to test correlations with stream temperature. These included land cover, mean August air temperature, and stream segment azimuth. Stream segment azimuth is discussed further in the section "Geographic Variables." Descriptive statistics for selected subbasin characteristics are presented in table 2.

Land cover was analyzed in two ways: 1) as the percent of the entire subbasin area and 2) as a percent of the area within a buffer drawn $100 \mathrm{~m}$ from each side of the stream. The source of the land cover data used in the first method was the National Land Cover Data (NLCD) for Idaho, version 2000-03. Stream lines were previously derived from digital elevation models and stored in USGS data archives.

\section{Data Collection and Processing}

Temperature data were collected using StowAway TidbiT temperature loggers programmed to record date, time, and temperature in degrees Celsius every hour. Accuracy of the temperature loggers was checked in the laboratory before and after deployment in the field (see section "Quality Control"). Field crews deployed temperature loggers as close to the outlet of a subbasin as possible. If it was not possible to deploy loggers in approximately the lower one-third of the subbasin, an alternate subbasin was used. In wadeable streams, the loggers were wired to a $1-\mathrm{m}$ piece of rebar pounded into the streambed at approximately midstream. Loggers were covered with foil to inhibit heating by direct sunlight. In large, unwadeable streams, loggers were deployed near the center of the stream from cables suspended from a bridge or anchored to rocks from the riverbank.

Data were downloaded from the loggers at the end of the deployment period and entered in computer spreadsheets. Each temperature record was inspected; incomplete or flawed data sets were eliminated. Timeseries plots also were made to screen the records for 


\section{EXPLANATION}

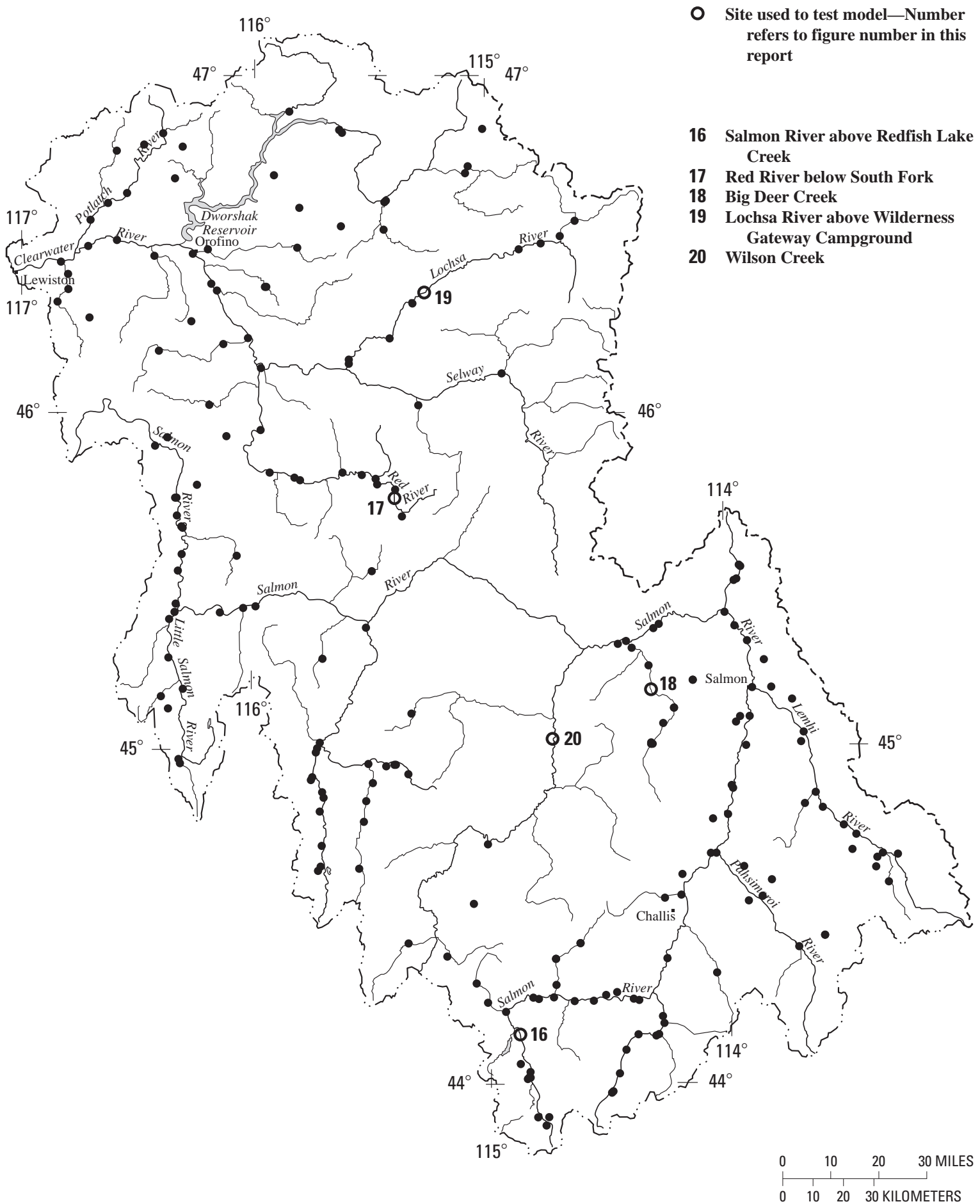

Figure 2. Monitored sites that provided stream-temperature data used to develop and test the statistical model, Salmon and Clearwater River Basins, central Idaho. 
Table 2. Statistical summary of selected subbasin and site characteristics for monitored sites used in the statistical model, Salmon and Clearwater River Basins, central Idaho

$\left[\mathrm{km}^{2}\right.$, square kilometers; $\mathrm{m}$, meters; ${ }^{\circ} \mathrm{C}$, degrees Celsius; $\mathrm{ft}$, feet; for measurements given in feet, multiply by 0.3048 to obtain meters $]$

\begin{tabular}{|c|c|c|c|c|c|c|c|}
\hline Characteristic & Description & $\begin{array}{l}\text { No. of } \\
\text { cases }\end{array}$ & Minimum & Maximum & Median & Mean & $\begin{array}{l}\text { Standard } \\
\text { deviation }\end{array}$ \\
\hline DRAINAREA & Sum of all upstream subbasin areas, in $\mathrm{km}^{2}$ & 183 & 28.5 & $34,851.0$ & 137.3 & $1,738.0$ & $5,940.2$ \\
\hline MSLOPE & Average slope of subbasin, in percent & 183 & 1.9 & 54.6 & 25.5 & 24.1 & 10.2 \\
\hline SOUTH & Percentage of subbasin area facing south & 182 & 0 & 35 & 11.8 & 11.5 & 6.4 \\
\hline SITEELEV & Site elevation, in $\mathrm{m}$ above sea level & 182 & 260 & 2,267 & 1,381 & $1,352.1$ & 5,201 \\
\hline MEANELEV & Average elevation of subbasin, in $\mathrm{m}$ above sea level & 183 & 501 & 2,744 & $1,965.0$ & $1,849.0$ & 518 \\
\hline AREASQKM & Area of subbasin, in $\mathrm{km}^{2}$ & 183 & 0.5 & 233.5 & 59.4 & 69.7 & 49.5 \\
\hline FOREST & $\begin{array}{l}\text { Percentage of subbasin area covered by forest (all types } \\
\text { combined) }\end{array}$ & 182 & 0 & 99 & 73 & 64.7 & 27.2 \\
\hline WETLAND & Percentage of subbasin area covered by wetland & 183 & 0 & 9 & 0.13 & 0.5 & 1.2 \\
\hline BARREN & Percentage of subbasin area covered by barren land & 182 & 0 & 24 & 0.25 & 1.9 & 3.7 \\
\hline GRASS & Percentage of subbasin area covered by grassland & 182 & 0 & 37 & 3.9 & 6.2 & 6.7 \\
\hline OPENCAN & Open canopy angle measured in field & 152 & 0 & 100 & 49 & 51.5 & 26.2 \\
\hline $\mathrm{RCC}$ & Riparian canopy coverage measured in field & 177 & 0 & 100 & 44 & 45.5 & 32.3 \\
\hline AUGTEMPC & Mean August temperature, in ${ }^{\circ} \mathrm{C}$ & 183 & 18.7 & 32 & 25.3 & 25.5 & 2.8 \\
\hline WIDTHFT & Stream width measured in field, in $\mathrm{ft}$ & 183 & 1.2 & 440.0 & 22.0 & 50.1 & 76.3 \\
\hline MDEPTHFT & Average stream depth measured in field, in $\mathrm{ft}$ & 169 & 0.2 & 14.0 & 0.9 & 1.4 & 1.6 \\
\hline SEGAZIMUTH & $\begin{array}{l}\text { Downstream azimuth of } 600 \text {-m-long stream segment } \\
\text { ending at site. Transformed using method of Bar- } \\
\text { tholow (1989). See text for discussion. }\end{array}$ & 176 & -89 & 90 & 1 & 2.0 & 46.8 \\
\hline
\end{tabular}

anomalous results such as evidence of emergence from the water or instrument malfunction. All files were edited to include only data from July 15 through September 10 , for a total of 1,392 hourly measurements (58 days), because this was the time interval that was recorded by all temperature loggers.

Of the 236 deployed temperature loggers, 19 were missing at the end of the deployment period. Data from 12 sites were unusable, either because the logger did not stay submerged in water or because of instrument malfunction. Data from 17 additional sites were eliminated from the analysis when it was determined that the sites were unsuitable for inclusion in model development (see discussion in section "Model Evaluation"). The final statistical model was developed from data from 183 sites ( 24 second-order streams, 75 thirdorder streams, 45 fourth-order streams, 28 fifth-order streams, 5 sixth-order streams, and 6 seventh-order streams).

\section{Quality Control}

The data loggers used in the study are stated by the manufacturer to be accurate to $0.40^{\circ} \mathrm{F}\left(0.22^{\circ} \mathrm{C}\right)$; their resolution is less than $0.32^{\circ} \mathrm{F}\left(0.18^{\circ} \mathrm{C}\right)$. All data loggers were tested before deployment by recording temperatures under controlled conditions. The loggers were placed in ice water for 2 hours; all loggers recorded temperatures within $0.2^{\circ}$ of $0^{\circ} \mathrm{C}$. The loggers also were placed in room-temperature distilled water 
Table 3. Selected stream-temperature metrics for monitored sites used in the statistical model, Salmon and Clearwater River Basins, central Idaho

[Stream name: R, River; Cr, Creek; N, North; S, South; W, West; E, East; Fk, Fork; C, Clearwater; S, Salmon. Units for stream-temperature metrics in degrees Celsius unless otherwise noted. Abbreviations: MDMT, maximum daily maximum temperature; MDAT, maximum daily average temperature; MWAT, maximum weekly average temperature; GAT, grand average temperature; $\mathrm{MAX} \Delta \mathrm{T}$, maximum diurnal variation; $\mathrm{BIG} \Delta \mathrm{T}$, total temperature variation during entire monitoring period; Percent $>13^{\circ} \mathrm{C}$, percent of monitoring period temperatures exceeded $13^{\circ} \mathrm{C}$; Percent $>22^{\circ} \mathrm{C}$, percent of monitoring period temperatures exceeded $22^{\circ} \mathrm{C} ;{ }^{\circ} \mathrm{C}$, degrees Celsius]

\begin{tabular}{|c|c|c|c|c|c|c|c|c|c|c|}
\hline Stream name & $\begin{array}{l}\text { River } \\
\text { basin }\end{array}$ & $\begin{array}{c}\text { Strahler } \\
\text { stream } \\
\text { order }\end{array}$ & MDMT & MDAT & MWAT & GAT & MAX $\Delta T$ & BIG $\Delta T$ & $\begin{array}{l}\text { Percent } \\
>13^{\circ} \mathrm{C}\end{array}$ & $\begin{array}{l}\text { Percent } \\
>22^{\circ} \mathrm{C}\end{array}$ \\
\hline American R & $\mathrm{C}$ & 4 & 26.0 & 21.6 & 20.4 & 16.3 & 9.6 & 17.6 & 77 & 7 \\
\hline Arnett $\mathrm{Cr}$ & $\mathrm{C}$ & 2 & 16.4 & 13.0 & 12.7 & 10.4 & 7.6 & 12.3 & 18 & 0 \\
\hline Basin $\mathrm{Cr}$ & $\mathrm{C}$ & 3 & 20.2 & 15.7 & 14.7 & 12.1 & 10.4 & 16.6 & 40 & 0 \\
\hline Bayhorse $\mathrm{Cr}$ & $\mathrm{C}$ & 3 & 22.2 & 17.9 & 16.6 & 14.1 & 10.3 & 15.7 & 60 & 0 \\
\hline Bear Valley Cr & $\mathrm{C}$ & 5 & 21.4 & 17.9 & 17.0 & 14.3 & 8.2 & 14.8 & 66 & 0 \\
\hline Bedrock Cr & $\mathrm{C}$ & 3 & 25.5 & 20.4 & 20.0 & 18.5 & 11.8 & 13.2 & 100 & 14 \\
\hline Big Bear Cr & $\mathrm{C}$ & 4 & 27.7 & 22.8 & 22.0 & 18.4 & 11.6 & 18.7 & 89 & 21 \\
\hline Big Canyon $\mathrm{Cr}$ & $\mathrm{C}$ & 4 & 25.2 & 21.7 & 21.0 & 18.5 & 8.3 & 12.4 & 100 & 14 \\
\hline Big Cr & $\mathrm{C}$ & 2 & 26.8 & 23.2 & 21.9 & 17.8 & 7.3 & 18.4 & 87 & 13 \\
\hline Big Cr N Fk & $\mathrm{C}$ & 2 & 15.5 & 11.9 & 11.1 & 9.6 & 7.1 & 10.9 & 8 & 0 \\
\hline Big Cr S Fk & $\mathrm{C}$ & 2 & 16.1 & 13.0 & 12.2 & 10.4 & 7.3 & 11.5 & 15 & 0 \\
\hline Big Eightmile $\mathrm{Cr}$ & $\mathrm{C}$ & 3 & 19.4 & 16.0 & 15.3 & 12.6 & 7.8 & 13.8 & 46 & 0 \\
\hline Big Timber $\mathrm{Cr}$ & $\mathrm{C}$ & 4 & 20.4 & 17.1 & 15.7 & 13.2 & 8.5 & 15.2 & 51 & 0 \\
\hline Big Timber $\mathrm{Cr}$ & $\mathrm{C}$ & 3 & 20.9 & 17.5 & 16.4 & 13.5 & 7.9 & 15.2 & 56 & 0 \\
\hline Blackmare $\mathrm{Cr}$ & $\mathrm{C}$ & 3 & 15.8 & 14.0 & 13.4 & 10.8 & 4.8 & 10.4 & 17 & 0 \\
\hline Bohannon $\mathrm{Cr}$ & $\mathrm{C}$ & 2 & 20.1 & 16.6 & 15.9 & 13.6 & 8.6 & 12.8 & 57 & 0 \\
\hline Boulder $\mathrm{Cr}$ & $\mathrm{C}$ & 4 & 19.2 & 15.4 & 14.4 & 11.4 & 8.4 & 14.9 & 32 & 0 \\
\hline Boulder $\mathrm{Cr}$ & $\mathrm{C}$ & 2 & 18.7 & 16.6 & 15.9 & 13.0 & 4.1 & 11.3 & 49 & 0 \\
\hline Boulder $\mathrm{Cr}$ & $\mathrm{C}$ & 3 & 21.7 & 20.3 & 18.3 & 15.3 & 5.8 & 12.4 & 79 & 0 \\
\hline Buckhorn $\mathrm{Cr}$ & $\mathrm{C}$ & 4 & 18.6 & 15.9 & 15.3 & 12.6 & 6.0 & 11.7 & 45 & 0 \\
\hline Buckhorn Cr W Fk & $\mathrm{C}$ & 4 & 17.9 & 15.8 & 15.3 & 12.4 & 5.1 & 11.5 & 43 & 0 \\
\hline Cape Horn Cr & $\mathrm{C}$ & 3 & 19.0 & 13.1 & 12.2 & 10.3 & 11.3 & 15.7 & 24 & 0 \\
\hline Challis $\mathrm{Cr}$ & $\mathrm{C}$ & 4 & 21.8 & 17.6 & 16.4 & 14.4 & 10.0 & 15.3 & 64 & 0 \\
\hline Clear $\mathrm{Cr}$ & $\mathrm{C}$ & 4 & 27.4 & 23.2 & 22.5 & 18.6 & 10.1 & 17.1 & 91 & 23 \\
\hline Clearwater $\mathrm{R}$ & $\mathrm{C}$ & 6 & 26.7 & 25.2 & 24.7 & 20.9 & 4.8 & 13.6 & 100 & 41 \\
\hline Clearwater $\mathrm{R}$ & $\mathrm{C}$ & 6 & 26.1 & 25.5 & 25.0 & 21.3 & 2.2 & 12.0 & 100 & 43 \\
\hline Clearwater $\mathrm{R}$ & $\mathrm{C}$ & 5 & 27.7 & 25.7 & 24.9 & 21.0 & 7.2 & 15.3 & 100 & 43 \\
\hline Clearwater R M Fk & $\mathrm{C}$ & 6 & 27.1 & 24.8 & 24.3 & 20.5 & 5.1 & 15.2 & 100 & 32 \\
\hline Clearwater R N Fk & $\mathrm{C}$ & 5 & 24.0 & 20.8 & 20.0 & 16.7 & 6.8 & 14.2 & 86 & 4 \\
\hline Clearwater R N Fk & $\mathrm{C}$ & 5 & 22.7 & 21.6 & 21.0 & 17.6 & 3.9 & 11.3 & 92 & 1 \\
\hline Clearwater R S Fk & $\mathrm{C}$ & 5 & 24.7 & 21.8 & 20.7 & 16.4 & 6.6 & 15.9 & 80 & 4 \\
\hline Clearwater R S Fk & $\mathrm{C}$ & 5 & 25.7 & 23.2 & 22.6 & 18.7 & 5.9 & 15.1 & 91 & 18 \\
\hline Clearwater R S Fk & $\mathrm{C}$ & 5 & 28.0 & 24.8 & 24.1 & 20.1 & 8.1 & 16.9 & 96 & 34 \\
\hline Corral $\mathrm{Cr}$ & $\mathrm{C}$ & 3 & 26.9 & 22.9 & 22.4 & 18.7 & 10.0 & 18.4 & 90 & 24 \\
\hline Cottonwood $\mathrm{Cr}$ & $\mathrm{C}$ & 3 & 24.8 & 21.7 & 20.8 & 17.4 & 6.7 & 14.2 & 89 & 7 \\
\hline Cottonwood $\mathrm{Cr}$ & $\mathrm{C}$ & 4 & 25.8 & 22.9 & 22.2 & 19.5 & 8.2 & 13.2 & 100 & 23 \\
\hline Crooked Cr & $\mathrm{C}$ & 2 & 20.4 & 16.6 & 15.6 & 12.1 & 8.6 & 15.7 & 40 & 0 \\
\hline Crooked R & $\mathrm{C}$ & 3 & 23.4 & 20.4 & 19.4 & 15.9 & 7.3 & 14.3 & 80 & 1 \\
\hline Curtis $\mathrm{Cr}$ & $\mathrm{C}$ & 3 & 19.0 & 15.3 & 14.4 & 11.4 & 7.3 & 14.4 & 31 & 0 \\
\hline Dahlonega $\mathrm{Cr}$ & $\mathrm{C}$ & 3 & 15.6 & 12.6 & 12.3 & 10.8 & 5.7 & 9.2 & 13 & 0 \\
\hline Fitsum $\mathrm{Cr}$ & $\mathrm{C}$ & 3 & 18.6 & 15.7 & 15.2 & 12.3 & 6.3 & 12.3 & 40 & 0 \\
\hline
\end{tabular}


Table 3. Selected stream-temperature metrics for monitored sites used in the statistical model, Salmon and Clearwater River Basins, central Idaho -Continued

\begin{tabular}{|c|c|c|c|c|c|c|c|c|c|c|}
\hline Stream name & $\begin{array}{l}\text { River } \\
\text { basin }\end{array}$ & $\begin{array}{l}\text { Strahler } \\
\text { stream } \\
\text { order }\end{array}$ & MDMT & MDAT & MWAT & GAT & MAX $\Delta T$ & BIG $\Delta T$ & $\begin{array}{l}\text { Percent } \\
>13^{\circ} \mathrm{C}\end{array}$ & $\begin{array}{c}\text { Percent } \\
>22^{\circ} \mathrm{C}\end{array}$ \\
\hline Fourmile $\mathrm{Cr}$ & $\mathrm{C}$ & 3 & 16.5 & 15.1 & 14.4 & 11.5 & 3.9 & 10.4 & 28 & 0 \\
\hline Fourth of July Cr & $\mathrm{C}$ & 3 & 24.8 & 16.0 & 14.7 & 11.1 & 17.9 & 23.4 & 33 & 2 \\
\hline French $\mathrm{Cr}$ & $\mathrm{C}$ & 3 & 19.7 & 16.2 & 15.2 & 12.1 & 7.5 & 13.5 & 39 & 0 \\
\hline French $\mathrm{Cr}$ & $\mathrm{C}$ & 3 & 21.5 & 19.7 & 19.1 & 15.7 & 4.0 & 12.7 & 82 & 0 \\
\hline Gedney $\mathrm{Cr}$ & $\mathrm{C}$ & 4 & 22.3 & 19.6 & 18.6 & 15.4 & 6.9 & 12.9 & 76 & 0 \\
\hline Germania $\mathrm{Cr}$ & $\mathrm{C}$ & 3 & 15.8 & 12.0 & 11.1 & 9.6 & 7.3 & 11.5 & 9 & 0 \\
\hline Goldburg Cr & $\mathrm{C}$ & 3 & 20.8 & 15.7 & 14.6 & 12.7 & 11.8 & 15.0 & 43 & 0 \\
\hline Grasshopper $\mathrm{Cr}$ & $\mathrm{C}$ & 3 & 29.5 & 24.2 & 23.4 & 18.2 & 18.4 & 23.6 & 76 & 27 \\
\hline Hard Cr & $\mathrm{C}$ & 3 & 21.8 & 18.6 & 17.9 & 14.4 & 6.4 & 15.0 & 71 & 0 \\
\hline Hat $\mathrm{Cr}$ & $\mathrm{C}$ & 3 & 22.2 & 17.8 & 16.8 & 14.5 & 9.9 & 15.0 & 65 & 0 \\
\hline Hayden $\mathrm{Cr}$ & $\mathrm{C}$ & 5 & 19.4 & 15.7 & 14.9 & 13.3 & 8.1 & 11.5 & 53 & 0 \\
\hline Haynes $\mathrm{Cr}$ & $\mathrm{C}$ & 2 & 19.8 & 16.1 & 15.7 & 13.2 & 8.1 & 13.3 & 52 & 0 \\
\hline Herd Cr & $\mathrm{S}$ & 4 & 20.3 & 15.4 & 14.4 & 13.0 & 11.1 & 14.2 & 47 & 0 \\
\hline Huckleberry $\mathrm{Cr}$ & $\mathrm{C}$ & 2 & 18.6 & 11.9 & 10.8 & 8.9 & 11.9 & 15.2 & 14 & 0 \\
\hline Iron $\mathrm{Cr}$ & $\mathrm{C}$ & 3 & 20.7 & 17.3 & 16.3 & 14.2 & 7.4 & 12.6 & 66 & 0 \\
\hline Isabella $\mathrm{Cr}$ & $\mathrm{C}$ & 3 & 18.0 & 16.1 & 15.4 & 13.2 & 4.1 & 8.4 & 52 & 0 \\
\hline Jim Ford Cr & $\mathrm{S}$ & 4 & 27.3 & 21.8 & 20.8 & 16.6 & 12.1 & 18.5 & 77 & 15 \\
\hline John Day Cr & $\mathrm{C}$ & 3 & 17.4 & 15.4 & 14.8 & 12.7 & 4.7 & 9.0 & 43 & 0 \\
\hline Johnson $\mathrm{Cr}$ & $\mathrm{S}$ & 4 & 19.3 & 15.2 & 14.6 & 11.8 & 8.3 & 14.3 & 35 & 0 \\
\hline Johnson $\mathrm{Cr}$ & $\mathrm{C}$ & 4 & 17.9 & 15.7 & 15.4 & 12.8 & 6.1 & 11.6 & 47 & 0 \\
\hline Johnson $\mathrm{Cr}$ & $\mathrm{S}$ & 3 & 19.7 & 17.2 & 16.5 & 13.2 & 6.2 & 14.0 & 58 & 0 \\
\hline Johnson $\mathrm{Cr}$ & $\mathrm{C}$ & 3 & 22.0 & 17.8 & 17.1 & 14.0 & 9.2 & 16.1 & 61 & 0 \\
\hline Kelly Cr & $\mathrm{C}$ & 5 & 23.6 & 20.1 & 19.1 & 15.7 & 8.2 & 15.1 & 76 & 2 \\
\hline Kinnikinic $\mathrm{Cr}$ & $\mathrm{C}$ & 2 & 15.4 & 12.6 & 11.9 & 10.3 & 5.9 & 9.8 & 11 & 0 \\
\hline Lake $\mathrm{Cr}$ & $\mathrm{S}$ & 3 & 15.4 & 12.4 & 11.7 & 9.5 & 6.5 & 10.7 & 9 & 0 \\
\hline Lawyer $\mathrm{Cr}$ & $\mathrm{S}$ & 4 & 25.1 & 21.3 & 20.2 & 16.0 & 10.6 & 17.9 & 71 & 11 \\
\hline Lawyer Cr & $\mathrm{S}$ & 4 & 31.5 & 24.9 & 23.8 & 19.4 & 14.9 & 21.8 & 88 & 31 \\
\hline Lemhi R & $\mathrm{C}$ & 5 & 17.8 & 12.3 & 11.5 & 10.1 & 11.1 & 12.8 & 22 & 0 \\
\hline Lemhi R & $\mathrm{S}$ & 4 & 21.6 & 15.8 & 15.0 & 13.4 & 12.0 & 15.4 & 51 & 0 \\
\hline Lemhi R & $\mathrm{S}$ & 5 & 20.2 & 16.8 & 15.9 & 14.1 & 8.4 & 12.4 & 66 & 0 \\
\hline Little N Fk Clearwater R & $\mathrm{S}$ & 5 & 19.5 & 17.8 & 17.3 & 14.6 & 3.6 & 10.1 & 73 & 0 \\
\hline Little Salmon R & $\mathrm{S}$ & 5 & 21.1 & 18.6 & 17.9 & 15.4 & 5.9 & 11.6 & 82 & 0 \\
\hline Little Slate $\mathrm{Cr}$ & $\mathrm{S}$ & 4 & 19.5 & 17.3 & 16.5 & 12.8 & 5.0 & 13.5 & 50 & 0 \\
\hline Lochsa R & $\mathrm{S}$ & 5 & 23.2 & 22.2 & 21.6 & 18.1 & 3.8 & 11.4 & 95 & 4 \\
\hline Lochsa R & $\mathrm{S}$ & 5 & 25.6 & 23.5 & 22.8 & 19.2 & 5.3 & 13.5 & 98 & 19 \\
\hline Lochsa R Crooked Fk & $\mathrm{S}$ & 4 & 22.0 & 17.5 & 16.4 & 13.4 & 9.3 & 15.4 & 51 & 0 \\
\hline Lochsa R Crooked Fk & $\mathrm{S}$ & 5 & 21.2 & 18.2 & 17.2 & 14.1 & 7.7 & 13.5 & 63 & 0 \\
\hline Logan $\mathrm{Cr}$ & $\mathrm{S}$ & 3 & 13.8 & 11.8 & 11.4 & 9.2 & 4.6 & 9.3 & 2 & 0 \\
\hline Lolo $\mathrm{Cr}$ & $\mathrm{S}$ & 4 & 26.0 & 24.2 & 23.2 & 19.2 & 6.0 & 14.4 & 97 & 25 \\
\hline Long Hollow $\mathrm{Cr}$ & $\mathrm{S}$ & 3 & 20.1 & 17.3 & 16.2 & 13.2 & 7.6 & 13.3 & 50 & 0 \\
\hline McGowan Cr & $\mathrm{S}$ & 2 & 16.6 & 12.8 & 11.9 & 10.6 & 8.7 & 11.2 & 20 & 0 \\
\hline McKim Cr & $\mathrm{S}$ & 3 & 17.3 & 15.3 & 14.6 & 12.6 & 5.3 & 10.1 & 46 & 0 \\
\hline Meadow $\mathrm{Cr}$ & $\mathrm{S}$ & 4 & 21.4 & 20.1 & 19.1 & 15.7 & 3.5 & 11.7 & 84 & 0 \\
\hline Meadow $\mathrm{Cr}$ & $\mathrm{S}$ & 3 & 22.8 & 20.1 & 19.3 & 15.8 & 6.4 & 14.4 & 76 & 1 \\
\hline Mission $\mathrm{Cr}$ & $\mathrm{S}$ & 3 & 23.6 & 21.9 & 19.3 & 16.2 & 8.0 & 14.2 & 82 & 3 \\
\hline Moose Cr & $\mathrm{S}$ & 3 & 20.3 & 15.4 & 14.7 & 12.1 & 9.6 & 14.3 & 35 & 0 \\
\hline
\end{tabular}


Table 3. Selected stream-temperature metrics for monitored sites used in the statistical model, Salmon and Clearwater River Basins, central Idaho - Continued

\begin{tabular}{|c|c|c|c|c|c|c|c|c|c|c|}
\hline Stream name & $\begin{array}{l}\text { River } \\
\text { basin }\end{array}$ & $\begin{array}{c}\text { Strahler } \\
\text { stream } \\
\text { order }\end{array}$ & MDMT & MDAT & MWAT & GAT & MAX $\Delta T$ & $B I G \Delta T$ & $\begin{array}{l}\text { Percent } \\
>13^{\circ} \mathrm{C}\end{array}$ & $\begin{array}{l}\text { Percent } \\
>22^{\circ} \mathrm{C}\end{array}$ \\
\hline Morgan $\mathrm{Cr}$ & $\mathrm{S}$ & 3 & 15.6 & 13.2 & 12.5 & 10.9 & 5.4 & 9.6 & 17 & 0 \\
\hline Morgan $\mathrm{Cr}$ & $\mathrm{S}$ & 3 & 21.7 & 18.8 & 17.7 & 15.2 & 7.1 & 14.1 & 78 & 0 \\
\hline Morse $\mathrm{Cr}$ & $\mathrm{S}$ & 3 & 13.8 & 11.7 & 11.1 & 9.8 & 4.4 & 7.9 & 2 & 0 \\
\hline Moyer $\mathrm{Cr}$ & $\mathrm{S}$ & 3 & 17.8 & 14.8 & 14.0 & 11.5 & 8.4 & 13.4 & 31 & 0 \\
\hline Musgrove $\mathrm{Cr}$ & $\mathrm{S}$ & 2 & 18.0 & 14.3 & 13.6 & 11.3 & 7.6 & 12.8 & 25 & 0 \\
\hline Napias Cr & $\mathrm{S}$ & 2 & 20.8 & 15.0 & 14.5 & 12.1 & 11.7 & 16.3 & 38 & 0 \\
\hline Newsome $\mathrm{Cr}$ & $\mathrm{S}$ & 4 & 23.8 & 19.9 & 18.9 & 15.1 & 9.0 & 15.7 & 70 & 2 \\
\hline N F White Bird Cr & $\mathrm{S}$ & 3 & 22.5 & 20.4 & 19.8 & 16.7 & 5.9 & 11.9 & 87 & 1 \\
\hline $\mathrm{O}^{\prime} \mathrm{Hara} \mathrm{Cr}$ & $\mathrm{S}$ & 4 & 22.5 & 18.9 & 18.1 & 14.8 & 7.8 & 13.9 & 71 & 1 \\
\hline Orogrande $\mathrm{Cr}$ & $\mathrm{S}$ & 3 & 19.5 & 16.0 & 15.1 & 12.1 & 8.1 & 13.6 & 37 & 0 \\
\hline Owl Cr & $\mathrm{S}$ & 3 & 20.0 & 17.7 & 17.0 & 13.9 & 4.9 & 11.6 & 67 & 0 \\
\hline Pahsimeroi R & $\mathrm{S}$ & 5 & 17.8 & 14.5 & 13.5 & 12.3 & 8.0 & 10.3 & 38 & 0 \\
\hline Panther $\mathrm{Cr}$ & $\mathrm{S}$ & 5 & 22.8 & 16.9 & 15.9 & 12.9 & 12.2 & 18.1 & 45 & 0 \\
\hline Panther Cr & $\mathrm{S}$ & 4 & 21.7 & 17.7 & 16.6 & 13.5 & 10.2 & 15.9 & 54 & 0 \\
\hline Panther $\mathrm{Cr}$ & $\mathrm{S}$ & 3 & 22.6 & 19.1 & 18.5 & 15.3 & 6.8 & 13.7 & 79 & 0 \\
\hline Papoose Cr & $\mathrm{S}$ & 3 & 18.3 & 15.4 & 14.7 & 12.4 & 5.6 & 10.5 & 39 & 0 \\
\hline Patterson $\mathrm{Cr}$ & $\mathrm{S}$ & 3 & 19.7 & 14.4 & 13.4 & 11.8 & 11.1 & 14.9 & 36 & 0 \\
\hline Peasley $\mathrm{Cr}$ & $\mathrm{S}$ & 2 & 20.3 & 17.8 & 17.0 & 13.8 & 5.9 & 13.1 & 62 & 0 \\
\hline Perreau $\mathrm{Cr}$ & $\mathrm{S}$ & 2 & 16.0 & 14.2 & 13.7 & 11.8 & 4.0 & 9.2 & 28 & 0 \\
\hline Pete King Cr & $\mathrm{S}$ & 3 & 23.0 & 19.5 & 18.7 & 15.5 & 8.3 & 13.7 & 76 & 1 \\
\hline Pine $\mathrm{Cr}$ & $\mathrm{S}$ & 2 & 17.1 & 15.5 & 15.0 & 12.3 & 3.9 & 9.6 & 38 & 0 \\
\hline Pole Cr & $\mathrm{S}$ & 3 & 15.1 & 10.0 & 9.4 & 8.2 & 9.5 & 12.0 & 6 & 0 \\
\hline Potlatch R & $\mathrm{S}$ & 5 & 30.0 & 26.0 & 25.4 & 21.7 & 9.3 & 17.2 & 100 & 47 \\
\hline Potlatch R & $\mathrm{S}$ & 5 & 27.6 & 23.8 & 23.1 & 19.6 & 9.0 & 16.8 & 96 & 27 \\
\hline Potlatch R & S & 5 & 29.6 & 25.0 & 24.4 & 21.0 & 10.5 & 17.5 & 99 & 40 \\
\hline Potlatch R E Fk & $\mathrm{S}$ & 3 & 25.9 & 21.3 & 20.8 & 17.1 & 10.3 & 17.9 & 80 & 16 \\
\hline Profile $\mathrm{Cr}$ & $\mathrm{S}$ & 3 & 14.9 & 11.8 & 11.6 & 9.6 & 5.7 & 10.1 & 6 & 0 \\
\hline Quartz Cr & $\mathrm{S}$ & 2 & 26.9 & 21.3 & 20.2 & 16.3 & 11.0 & 19.4 & 75 & 10 \\
\hline Race $\mathrm{Cr}$ & $\mathrm{S}$ & 3 & 16.7 & 14.8 & 14.4 & 13.2 & 4.1 & 6.4 & 50 & 0 \\
\hline Red R & $\mathrm{S}$ & 4 & 24.0 & 21.7 & 20.7 & 16.3 & 6.8 & 15.3 & 79 & 3 \\
\hline $\operatorname{Red~R}$ & $\mathrm{S}$ & 4 & 26.7 & 22.6 & 21.2 & 16.9 & 10.3 & 18.8 & 81 & 12 \\
\hline Red R S Fk & $\mathrm{S}$ & 3 & 23.0 & 18.5 & 17.4 & 13.5 & 10.4 & 17.9 & 55 & 1 \\
\hline Reeds Cr & $S$ & 3 & 25.0 & 20.8 & 19.8 & 16.0 & 9.3 & 17.3 & 75 & 7 \\
\hline Rice $\mathrm{Cr}$ & $\mathrm{S}$ & 3 & 24.1 & 21.5 & 20.9 & 17.4 & 6.3 & 13.6 & 91 & 7 \\
\hline Riordan $\mathrm{Cr}$ & $\mathrm{S}$ & 3 & 17.3 & 15.2 & 14.7 & 11.8 & 5.9 & 11.5 & 34 & 0 \\
\hline Rock Cr & $\mathrm{S}$ & 4 & 23.6 & 19.6 & 19.0 & 16.6 & 8.4 & 12.6 & 93 & 4 \\
\hline Round Valley Cr & S & 2 & 14.4 & 12.4 & 11.8 & 9.8 & 4.5 & 9.0 & 4 & 0 \\
\hline Salmon R & $\mathrm{S}$ & 7 & 19.9 & 15.2 & 14.3 & 12.2 & 10.5 & 15.0 & 40 & 0 \\
\hline Salmon R & $\mathrm{S}$ & 7 & 19.8 & 15.4 & 14.4 & 12.2 & 10.4 & 14.8 & 40 & 0 \\
\hline Salmon R & $\mathrm{S}$ & 7 & 25.1 & 16.8 & 16.0 & 13.0 & 17.4 & 23.3 & 45 & 6 \\
\hline Salmon R & $\mathrm{S}$ & 7 & 21.0 & 18.5 & 17.5 & 15.1 & 7.5 & 13.0 & 82 & 0 \\
\hline Salmon R & $\mathrm{S}$ & 7 & 22.6 & 19.0 & 17.8 & 15.4 & 8.2 & 15.1 & 77 & 0 \\
\hline Salmon R & $\mathrm{S}$ & 7 & 23.0 & 21.0 & 20.2 & 17.8 & 5.3 & 11.7 & 96 & 2 \\
\hline Salmon R & $\mathrm{S}$ & 6 & 23.7 & 22.2 & 21.5 & 18.2 & 3.8 & 11.3 & 99 & 5 \\
\hline Salmon R & $\mathrm{S}$ & 5 & 23.2 & 23.0 & 22.4 & 18.8 & 7.0 & 10.0 & 100 & 10 \\
\hline
\end{tabular}


Table 3. Selected stream-temperature metrics for monitored sites used in the statistical model, Salmon and Clearwater River Basins, central Idaho - Continued

\begin{tabular}{|c|c|c|c|c|c|c|c|c|c|c|}
\hline Stream name & $\begin{array}{l}\text { River } \\
\text { basin }\end{array}$ & $\begin{array}{c}\text { Strahler } \\
\text { stream } \\
\text { order }\end{array}$ & MDMT & MDAT & MWAT & GAT & MAX $\Delta \mathbf{T}$ & BIG $\Delta \mathrm{T}$ & $\begin{array}{l}\text { Percent } \\
>13^{\circ} \mathrm{C}\end{array}$ & $\begin{array}{l}\text { Percent } \\
>22^{\circ} \mathrm{C}\end{array}$ \\
\hline Salmon R & $\mathrm{S}$ & 5 & 23.9 & 23.1 & 22.7 & 19.2 & 1.8 & 10.2 & 100 & 15 \\
\hline Salmon R & $\mathrm{S}$ & 5 & 23.8 & 23.2 & 22.9 & 19.4 & 1.8 & 9.9 & 100 & 17 \\
\hline Salmon R & $\mathrm{S}$ & 5 & 23.9 & 23.3 & 22.9 & 19.4 & 1.8 & 9.9 & 100 & 17 \\
\hline Salmon R & $\mathrm{S}$ & 5 & 29.7 & 23.6 & 23.3 & 19.8 & 3.3 & 15.6 & 100 & 23 \\
\hline Salmon R E Fk & $\mathrm{S}$ & 5 & 18.7 & 14.3 & 13.5 & 12.1 & 9.7 & 12.4 & 35 & 0 \\
\hline Salmon R E Fk & $\mathrm{S}$ & 4 & 17.6 & 14.3 & 13.4 & 11.9 & 7.3 & 11.4 & 33 & 0 \\
\hline Salmon R E Fk & $\mathrm{S}$ & 4 & 19.5 & 15.3 & 14.4 & 13.3 & 9.1 & 11.5 & 48 & 0 \\
\hline Salmon R E Fk & $\mathrm{S}$ & 3 & 21.0 & 16.5 & 15.4 & 14.0 & 9.6 & 13.3 & 57 & 0 \\
\hline Salmon R M Fk & $\mathrm{S}$ & 6 & 18.7 & 12.9 & 12.1 & 10.3 & 11.9 & 15.5 & 26 & 0 \\
\hline Salmon R M Fk & $\mathrm{S}$ & 3 & 20.4 & 18.3 & 17.6 & 14.9 & 4.8 & 12.0 & 79 & 0 \\
\hline Salmon R N Fk & $S$ & 3 & 18.8 & 15.7 & 15.1 & 12.4 & 6.6 & 12.7 & 41 & 0 \\
\hline Salmon R N Fk & $\mathrm{S}$ & 4 & 19.5 & 16.1 & 15.6 & 13.2 & 6.7 & 11.7 & 51 & 0 \\
\hline Salmon R N Fk & $S$ & 4 & 21.0 & 17.2 & 16.5 & 14.0 & 7.7 & 13.1 & 63 & 0 \\
\hline Salmon R S Fk & $\mathrm{S}$ & 4 & 21.8 & 17.9 & 16.9 & 13.8 & 8.5 & 15.6 & 58 & 0 \\
\hline Salmon R S Fk & $S$ & 4 & 22.3 & 19.2 & 18.7 & 10.4 & 6.9 & 14.3 & 90 & 1 \\
\hline Salmon R S Fk E Fk & $\mathrm{S}$ & 5 & 18.1 & 14.2 & 13.9 & 11.4 & 7.5 & 12.7 & 29 & 0 \\
\hline Salmon R S Fk E Fk & $\mathrm{S}$ & 4 & 16.1 & 14.3 & 13.9 & 11.8 & 4.2 & 8.7 & 28 & 0 \\
\hline Salmon R S Fk E Fk & $\mathrm{S}$ & 4 & 19.0 & 17.4 & 17.0 & 14.2 & 3.2 & 10.8 & 76 & 0 \\
\hline Sandy Cr & $S$ & 2 & 19.2 & 16.6 & 16.1 & 14.1 & 5.8 & 11.1 & 68 & 0 \\
\hline S F White Bird Cr & $\mathrm{S}$ & 3 & 22.3 & 20.2 & 19.6 & 16.2 & 6.0 & 12.9 & 84 & 0 \\
\hline Sheep Cr & $S$ & 3 & 14.1 & 11.5 & 11.1 & 9.6 & 5.1 & 8.7 & 2 & 0 \\
\hline Silver $\mathrm{Cr}$ & $\mathrm{S}$ & 3 & 20.0 & 17.3 & 16.5 & 13.5 & 6.3 & 11.8 & 55 & 0 \\
\hline Silver $\mathrm{Cr}$ & $\mathrm{S}$ & 2 & 19.8 & 17.8 & 17.0 & 13.5 & 5.3 & 12.8 & 59 & 0 \\
\hline Skookumchuck Cr & $\mathrm{S}$ & 3 & 23.6 & 21.1 & 20.7 & 18.0 & 5.9 & 11.3 & 98 & 6 \\
\hline Slate $\mathrm{Cr}$ & $\mathrm{S}$ & 3 & 19.3 & 13.3 & 12.6 & 11.1 & 11.1 & 14.3 & 28 & 0 \\
\hline Smiley $\mathrm{Cr}$ & $\mathrm{S}$ & 3 & 21.0 & 16.8 & 15.8 & 13.1 & 9.6 & 16.0 & 49 & 0 \\
\hline Squaw $\mathrm{Cr}$ & $\mathrm{S}$ & 3 & 17.3 & 14.9 & 14.2 & 12.0 & 6.0 & 9.5 & 32 & 0 \\
\hline Squaw $\mathrm{Cr}$ & $\mathrm{S}$ & 4 & 21.3 & 16.7 & 15.7 & 13.3 & 11.4 & 16.2 & 50 & 0 \\
\hline Steamboat $\mathrm{Cr}$ & $\mathrm{S}$ & 2 & 18.9 & 14.4 & 13.9 & 11.3 & 8.9 & 14.2 & 28 & 0 \\
\hline Sulphur Cr & $\mathrm{S}$ & 2 & 23.3 & 17.1 & 16.6 & 15.4 & 10.7 & 12.3 & 79 & 1 \\
\hline Sweetwater $\mathrm{Cr}$ & $\mathrm{S}$ & 4 & 25.9 & 19.1 & 21.2 & 17.7 & 7.4 & 13.9 & 95 & 12 \\
\hline Sweetwater $\mathrm{Cr}$ & $\mathrm{S}$ & 4 & 24.6 & 22.2 & 20.9 & 17.8 & 9.0 & 15.8 & 92 & 14 \\
\hline Tamarack $\mathrm{Cr}$ & $\mathrm{S}$ & 3 & 17.1 & 12.4 & 12.1 & 10.2 & 8.4 & 12.1 & 20 & 0 \\
\hline Texas $\mathrm{Cr}$ & $\mathrm{S}$ & 3 & 22.4 & 17.5 & 16.3 & 14.0 & 11.4 & 16.6 & 58 & 0 \\
\hline Thompson $\mathrm{Cr}$ & $\mathrm{S}$ & 3 & 19.8 & 13.8 & 13.2 & 11.8 & 11.5 & 4.3 & 33 & 0 \\
\hline Three Bear $\mathrm{Cr}$ & $\mathrm{S}$ & 3 & 18.7 & 16.3 & 15.4 & 12.6 & 5.9 & 11.7 & 44 & 0 \\
\hline Threemile $\mathrm{Cr}$ & S & 2 & 24.4 & 21.0 & 20.2 & 16.4 & 10.3 & 16.0 & 79 & 7 \\
\hline Tom Beall $\mathrm{Cr}$ & $\mathrm{S}$ & 4 & 20.1 & 18.2 & 17.4 & 15.3 & 5.5 & 10.1 & 84 & 0 \\
\hline Tower $\mathrm{Cr}$ & $\mathrm{S}$ & 3 & 18.9 & 16.7 & 16.0 & 14.2 & 5.8 & 9.7 & 73 & 0 \\
\hline Trail Cr & S & 2 & 23.1 & 15.6 & 15.0 & 12.6 & 10.8 & 15.6 & 43 & 0 \\
\hline Twelvemile $\mathrm{Cr}$ & $\mathrm{S}$ & 3 & 15.5 & 13.2 & 12.6 & 10.9 & 5.0 & 9.4 & 14 & 0 \\
\hline Valley $\mathrm{Cr}$ & $\mathrm{S}$ & 3 & 20.5 & 15.3 & 14.1 & 12.1 & 11.0 & 16.3 & 37 & 0 \\
\hline Valley $\mathrm{Cr}$ & $\mathrm{S}$ & 4 & 24.0 & 18.3 & 17.1 & 14.1 & 18.7 & 20.0 & 62 & 2 \\
\hline Vanity $\mathrm{Cr}$ & $\mathrm{S}$ & 3 & 13.4 & 10.9 & 10.5 & 8.8 & 5.3 & 9.2 & 0 & 0 \\
\hline Weitas $\mathrm{Cr}$ & $S$ & 4 & 23.0 & 18.9 & 17.9 & 14.7 & 9.4 & 15.0 & 66 & 1 \\
\hline Weitas $\mathrm{Cr}$ & $\mathrm{S}$ & 4 & 23.5 & 20.2 & 19.1 & 15.7 & 7.5 & 14.2 & 77 & 1 \\
\hline
\end{tabular}


Table 3. Selected stream-temperature metrics for monitored sites used in the statistical model, Salmon and Clearwater River Basins, central Idaho - Continued

\begin{tabular}{|c|c|c|c|c|c|c|c|c|c|c|}
\hline Stream name & $\begin{array}{l}\text { River } \\
\text { basin }\end{array}$ & $\begin{array}{c}\text { Strahler } \\
\text { stream } \\
\text { order }\end{array}$ & MDMT & MDAT & MWAT & GAT & MAX $\Delta T$ & BIG $\Delta T$ & $\begin{array}{l}\text { Percent } \\
>13^{\circ} \mathrm{C}\end{array}$ & $\begin{array}{l}\text { Percent } \\
>22^{\circ} \mathrm{C}\end{array}$ \\
\hline Whiskey $\mathrm{Cr}$ & $\mathrm{S}$ & 3 & 23.8 & 20.4 & 19.6 & 16.8 & 7.0 & 12.7 & 90 & 3 \\
\hline White Bird Cr & $\mathrm{C}$ & 4 & 26.9 & 23.3 & 22.7 & 18.9 & 10.0 & 16.3 & 93 & 23 \\
\hline Williams Cr & $\mathrm{C}$ & 3 & 17.6 & 15.4 & 14.8 & 12.5 & 4.4 & 10.6 & 44 & 0 \\
\hline Yankee Fk & $S$ & 3 & 16.7 & 12.2 & 11.3 & 9.5 & 9.0 & 13.4 & 13 & 0 \\
\hline Yankee Fk & $S$ & 4 & 19.6 & 14.9 & 13.9 & 11.8 & 10.2 & 15.4 & 35 & 0 \\
\hline
\end{tabular}

along with a calibrated thermometer for 2 hours. All loggers recorded temperatures within $0.7^{\circ} \mathrm{C}$ of the reference thermometer. After retrieval, 15 of the loggers were tested by overnight refrigeration. Recorded temperatures varied by no more than $0.32^{\circ} \mathrm{C}$ during the 13 hours after temperatures stabilized. They also were tested for 30 minutes in an ice bath. All loggers recorded temperatures within $0.4^{\circ}$ of $0^{\circ} \mathrm{C}$, and individual logger temperatures varied no more than $0.3^{\circ} \mathrm{C}$ during the test.
Pairs of temperature loggers were deployed at eight sites in order to provide duplicate temperature records for the entire deployment period: two sites on the Salmon River, two sites on the Clearwater River, and one site each on the Middle Fork Clearwater River, Lemhi River, Valley Creek, and the Potlatch River. Both loggers from the Potlatch River site were lost. Paired loggers usually were deployed on opposite banks of the stream. Paired data were retrieved from seven of the sites. Data showed excellent agreement

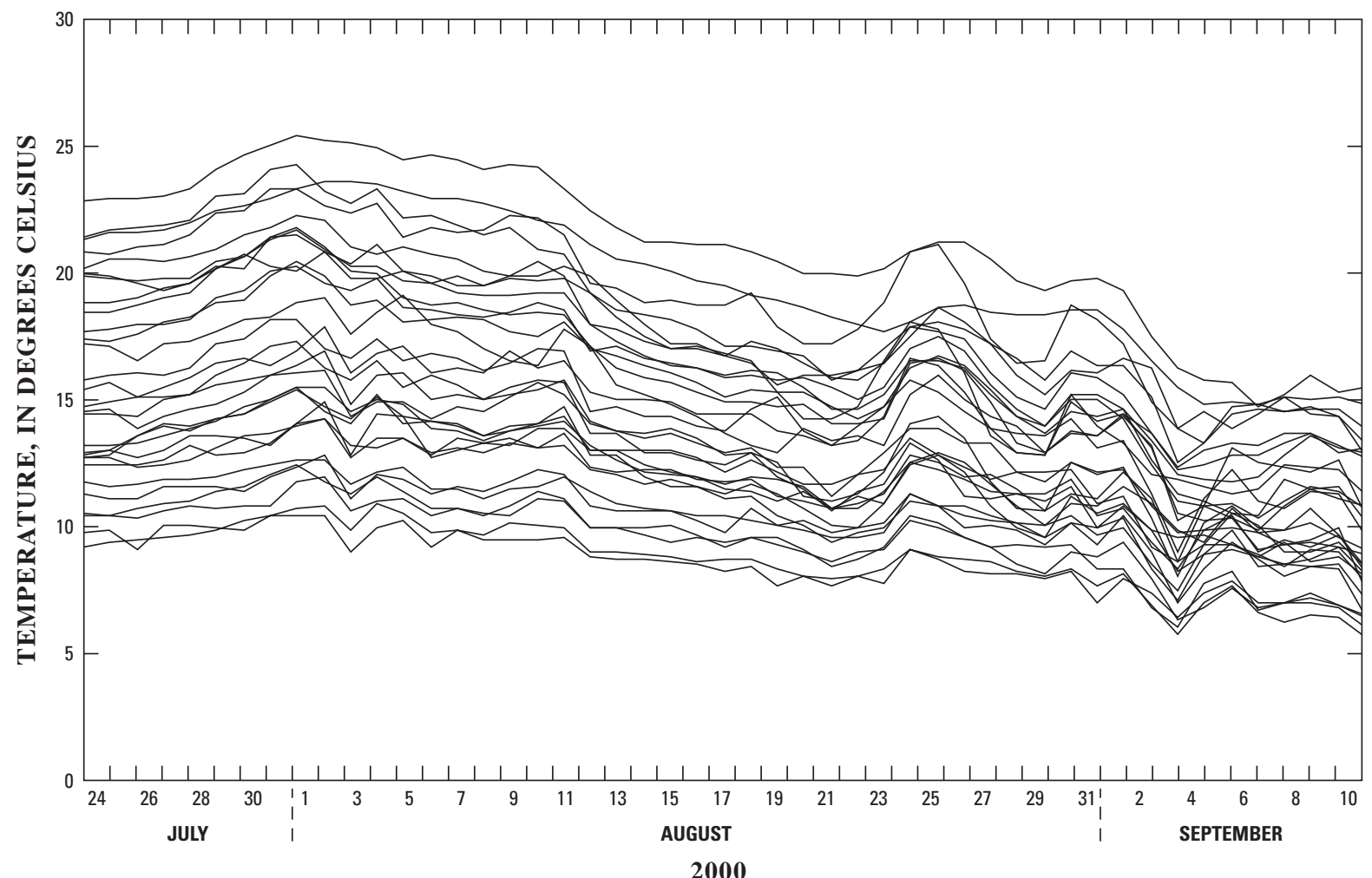

Figure 3. Daily average temperature for representative streams in the Salmon and Clearwater River Basins, central Idaho. 
Table 4. Statistical summary, grouped by stream order, of selected stream-temperature metrics for monitored sites used in the statistical model, Salmon and Clearwater River Basins, central Idaho

[Abbreviations: MDMT, maximum daily maximum temperature; MDAT, maximum daily average temperature; MDNT, maximum daily minimum temperature; MWMT, maximum weekly maximum temperature; MWAT, maximum weekly average temperature; $\mathrm{MAX} \Delta \mathrm{T}$, maximum diurnal variation; $\mathrm{BIG} \Delta \mathrm{T}$, highest recorded temperature minus lowest recorded temperature for measurement period; GAT, grand average temperature; all stream-temperature metrics are in ${ }^{\circ} \mathrm{C} ;$ No., number]

\begin{tabular}{|c|c|c|c|c|c|c|c|c|}
\hline \multicolumn{9}{|c|}{ Stream-temperature metric } \\
\hline & MDMT & MDAT & MDNT & MWMT & MWAT & MAX $\Delta T$ & BIG $\Delta \mathbf{T}$ & GAT \\
\hline \multicolumn{9}{|c|}{$2^{\text {nd }}$ - and $3^{\text {rd }}$-order streams } \\
\hline No. of sites & 99 & 99 & 99 & 98 & 99 & 99 & 99 & 99 \\
\hline Minimum & 13.4 & 10.0 & 7.2 & 11.9 & 9.4 & 3.9 & 6.4 & 8.2 \\
\hline Maximum & 29.5 & 24.2 & 20.4 & 28.9 & 23.4 & 18.4 & 23.6 & 19.5 \\
\hline Mean & 19.7 & 16.2 & 13.8 & 18.7 & 15.4 & 7.8 & 13.2 & 12.9 \\
\hline $\begin{array}{l}\text { Standard } \\
\text { deviation }\end{array}$ & 3.4 & 3.1 & 2.9 & 3.4 & 3.1 & 2.8 & 3.1 & 2.5 \\
\hline \multicolumn{9}{|c|}{$4^{\text {th }}$ - and $5^{\text {th }}$-order streams } \\
\hline No. of sites & 73 & 73 & 71 & 73 & 73 & 73 & 73 & 73 \\
\hline Minimum & 16.1 & 12.3 & 9.6 & 15.5 & 11.5 & 3.2 & 8.7 & 10.1 \\
\hline Maximum & 31.5 & 26.0 & 23.6 & 30.7 & 25.4 & 18.7 & 23.3 & 21.7 \\
\hline Mean & 22.6 & 19.1 & 16.3 & 21.7 & 18.3 & 8.3 & 14.4 & 15.3 \\
\hline $\begin{array}{l}\text { Standard } \\
\text { deviation } \\
\end{array}$ & 3.3 & 3.2 & 3.1 & 3.4 & 3.2 & 2.8 & 2.7 & 2.6 \\
\hline \multicolumn{9}{|c|}{$6^{\text {th }}$ - and $7^{\text {th }}$-order streams } \\
\hline No. of sites & 11 & 11 & 11 & 11 & 11 & 11 & 11 & 11 \\
\hline Minimum & 20.4 & 18.3 & 16.4 & 19.5 & 17.6 & 1.8 & 9.9 & 14.9 \\
\hline Maximum & 27.7 & 25.7 & 24.6 & 27.1 & 25.0 & 7.2 & 15.6 & 21.3 \\
\hline Mean & 24.3 & 23.0 & 21.8 & 23.7 & 22.5 & 4.0 & 12.1 & 19.1 \\
\hline $\begin{array}{l}\text { Standard } \\
\text { deviation } \\
\end{array}$ & 2.0 & 2.1 & 2.4 & 2.1 & 2.2 & 2.0 & 2.2 & 1.8 \\
\hline
\end{tabular}

(differences less than $1^{\circ} \mathrm{C}$ ) at five of the seven sites. The record from one of the loggers at Valley Creek indicated intermittent emergence from the water after approximately August 5. The data from one of the Clearwater River sites agreed within approximately $1.5^{\circ} \mathrm{C}$ for most of the deployment period but differed intermittently by as much as approximately $2.6^{\circ} \mathrm{C}$ later in the summer. There was no evidence of instrument malfunction or emergence, but the recorded temperature differences were not considered unreasonable because the river at the site is $94 \mathrm{~m}$ wide; end-of-summer differences in water depth or exposure to sunlight between the two loggers could explain the divergence.

\section{CHARACTERIZATION OF STREAM TEMPERATURES}

\section{Temperature Metrics}

Several temperature metrics are of special interest to biological resource managers because they help characterize the thermal regime in stream temperatures. Selected temperature metrics derived from the data for monitored sites used in the statistical model are presented in table 3. Stream temperature metrics varied with stream order. Statistical summaries of selected temperature metrics, grouped by stream order, are presented in table 4 .

\section{Graphical Display of Temperature Data}

Daily average stream temperatures were calculated for all sites and plotted on graphs showing temperature as a function of time. Temperatures for representative streams are shown in figure 3. Temperature patterns for all sites monitored in this study were remarkably similar. Temperatures generally increased slightly during the first 7 to 10 days of the deployment period, July 15, 2000, to September 10, 2000, and reached the maximum temperature for the year between July 31 and August 2. This maximum generally was followed by a gradual decrease in temperature for the rest of the period, except for notable short-term temperature spikes on approximately August 24 to 25 and from August 28 to September 1. These temperature patterns correspond to daily average air-temperature patterns for central Idaho during the deployment period.

Distinctive temperature patterns for several sites on the lower Salmon River and the Clearwater River reflect very low diurnal fluctuation, between approximately $1.5^{\circ}$ and $3^{\circ} \mathrm{C}$. At these sites the rivers are more than $60 \mathrm{~m}$ wide and, in most cases, are approximately $2 \mathrm{~m}$ deep. Time-temperature graphs of these rivers differ greatly from those of smaller streams, which show greater diurnal fluctuation (example shown in fig. 4). The low diurnal variation is best explained by the large thermal mass in relation to the surface area of the larger rivers, which dampens short-term temperature fluctuations.

Quantile diagrams were constructed for several temperature metrics. The quantile of a sample is the data point corresponding to a given fraction of the data; 


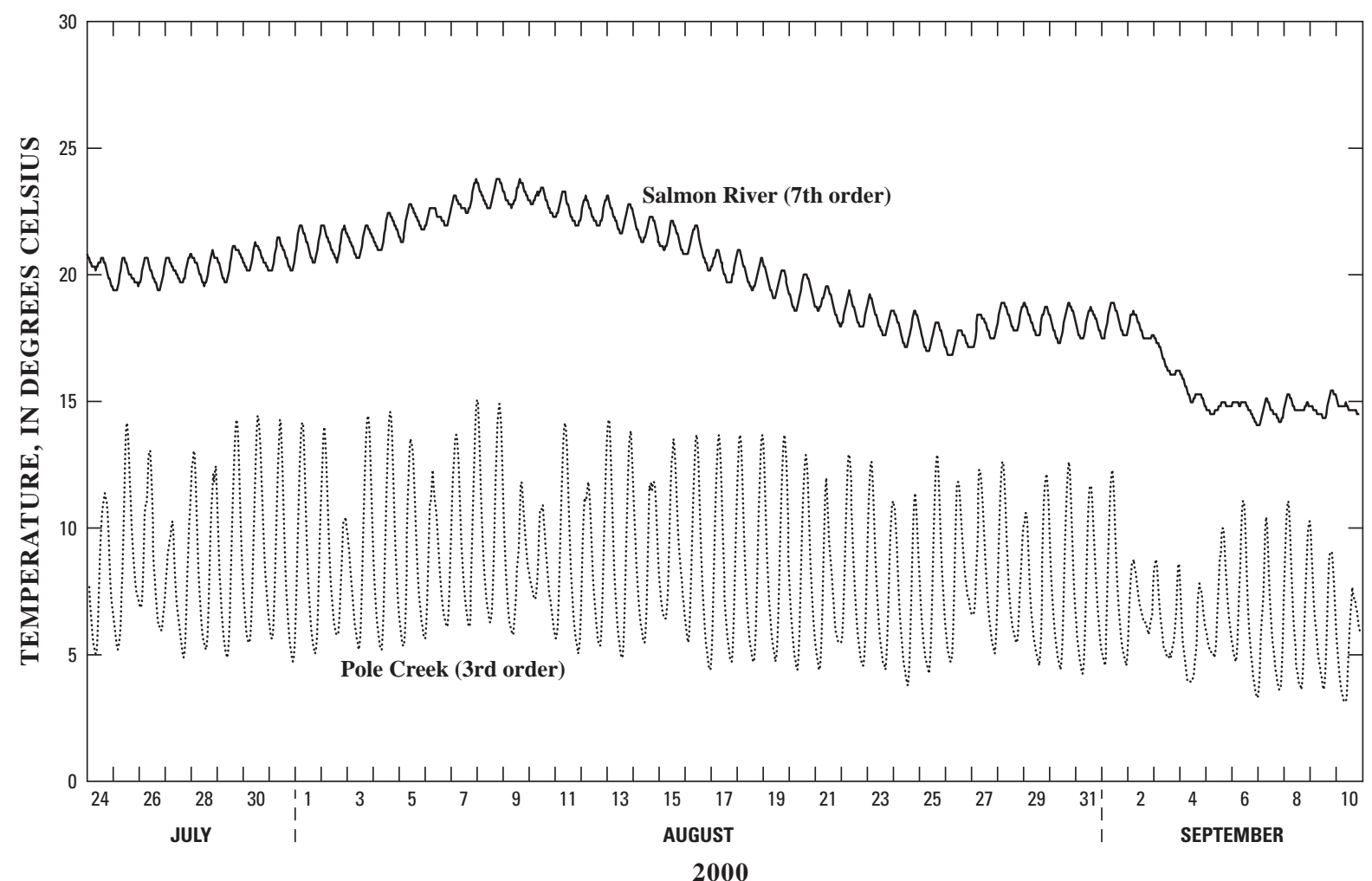

Figure 4. Hourly temperature for streams with contrasting diurnal temperature fluctuation in the Salmon and Clearwater River Basins, central Idaho.

therefore, quantile diagrams are useful for understanding the range and overall distribution of the entire data set. Quantile diagrams of maximum daily average temperature (MDAT) for all sites, grouped by stream order, are given in figure 5. Each data point in figure 5 represents the MDAT for the deployment period for one site. For most sites, the date of the MDAT was the same as the early-August peak temperature referred to on the previous page. The vertical lines represent regulatory threshold temperatures of $9^{\circ}$ and $19^{\circ} \mathrm{C}$ for salmonid spawning and cold-water biota, respectively. The Yaxis values at the intersection of these lines with a data curve indicate the fraction of the sites that are below those temperatures. Temperatures of all streams, regardless of stream order, exceeded $9{ }^{\circ} \mathrm{C}$; those of approximately 80 percent of second- and third-order streams were below $19^{\circ} \mathrm{C}$; those of approximately 45 percent of fourth- and fifth-order streams were below $19^{\circ} \mathrm{C}$.

Another useful diagram is a type of exceedance curve, which shows the percentage of the deployment period that the temperature of a stream exceeded a given threshold. Several exceedance curves are shown in figure 6. Each curve represents all the temperature measurements from one stream. In general, lower order streams plotted toward the left side of the diagram (cooler temperatures), and higher order streams plotted toward the right side (warmer temperatures). Vertical lines are drawn from a temperature to a curve; the $\mathrm{Y}-$ value at the intersection of these lines with a data curve indicates the percentage of the deployment period that the temperature of the stream exceeded that temperature. Vertical lines in figure 6 represent $9^{\circ} \mathrm{C}$ and $19^{\circ} \mathrm{C}$. Thus, the stream represented by the heavy dashed line exceeded $9^{\circ} \mathrm{C}$ approximately 95 percent of the time and exceeded $19^{\circ} \mathrm{C}$ less than 10 percent of the time.

\section{Idaho Stream-Temperature Standards}

The current (April 2002) temperature standards for salmonid spawning and cold-water biota for Idaho 


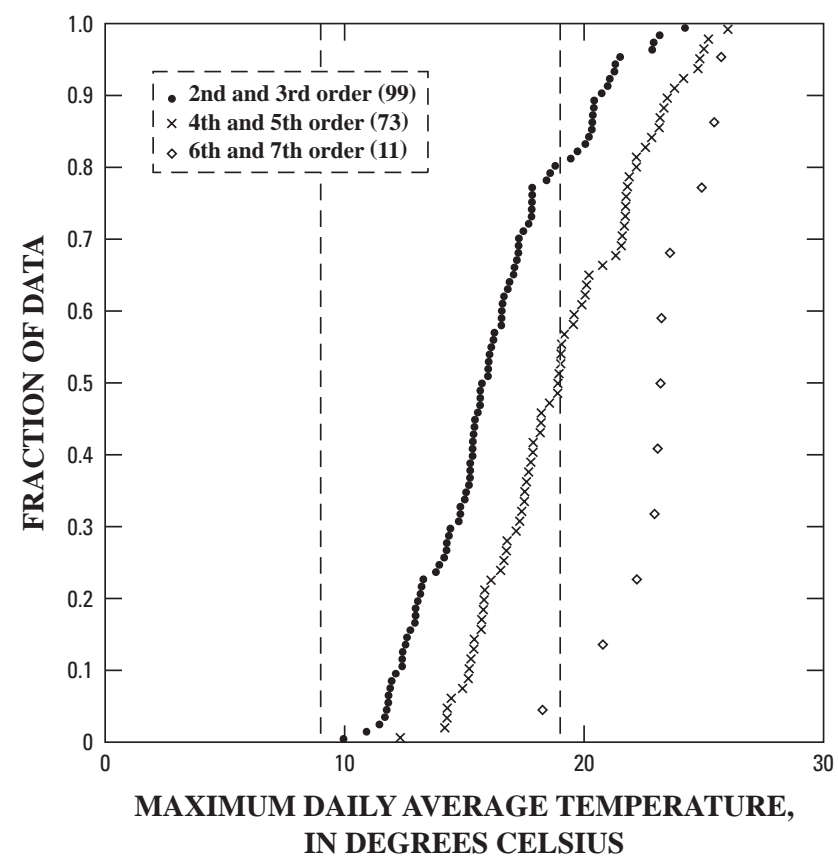

Figure 5. Quantile diagram for selected streams in the Salmon and Clearwater River Basins, central Idaho. (Vertical lines at 9 and 19 degrees Celsius represent temperature standards for salmonid spawning and cold-water biota, respectively)

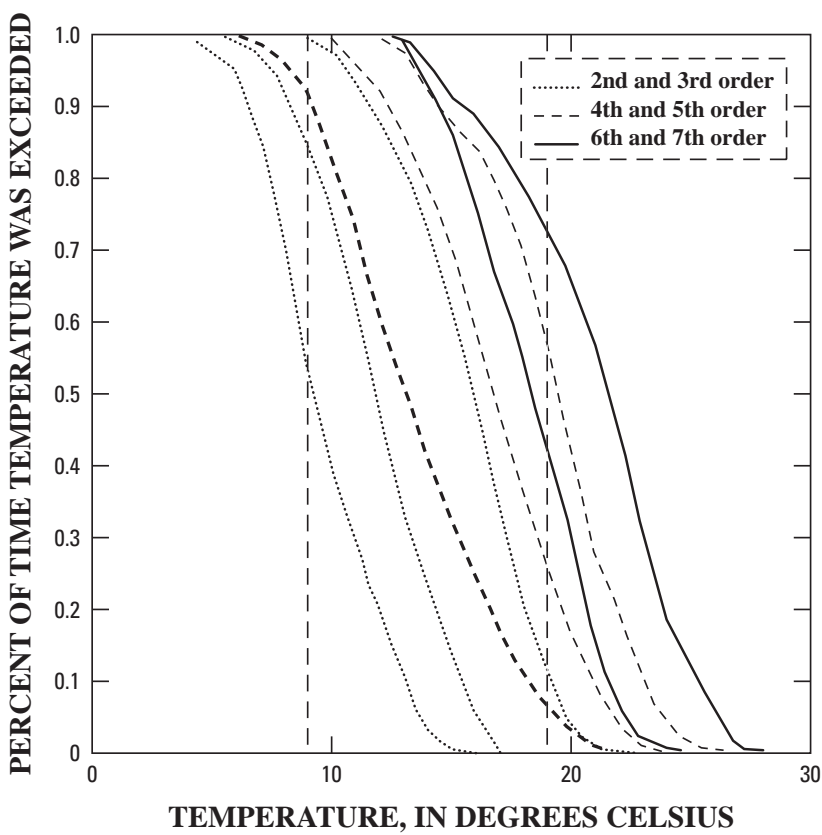

Figure 6. Exceedance curves for representative streams in the Salmon and Clearwater River Basins, central Idaho. (Vertical lines at 9 and 19 degrees Celsius represent temperature standards for salmonid spawning and cold-water biota, respectively) streams are summarized in table 5. Temperature data were analyzed to determine which sites met the current Idaho temperature standards. The results for the coldwater biota standards are shown in figure 7. One hundred nineteen of the 183 sites used in the model met the maximum daily average temperature standard of $19^{\circ} \mathrm{C}$; 110 sites met the instantaneous maximum temperature standard of $22^{\circ} \mathrm{C}$. Most of the sites that met the standards are in the Salmon River Basin. None of the sites met the current Idaho temperature standard for salmonid spawning (maximum daily average temperature, $\leq 9^{\circ} \mathrm{C}$; instantaneous maximum, $\leq 13^{\circ} \mathrm{C}$ ).

\section{STATISTICAL ANALYSIS}

Statistical tests were used to identify relationships between stream temperature and subbasin and site characteristics. The factors that influence stream temperature generally are well documented and are the basis for several widely used models that use equations to describe heat exchange between streams and their environment (Sullivan and others, 1990). Important heat sources include solar, atmospheric, and topographic radiation. Heat exchange occurs by convection, conduction, and evaporation at the water-air interface and by conduction at the water-streambed interface. Cooling (and heating, in geothermal areas) by advection from ground-water inflow is another important process affecting stream temperature and is one that is difficult to quantify without detailed study of a particular site. Back-radiation by the water is a mechanism of heat loss. Overall, any subbasin and site characteristics that have bearing on these heat exchange processes, such as presence of riparian vegetation, direction of streamflow, and slope facing direction, are likely to

Table 5. Current Idaho stream-temperature standards for aquatic life designations ${ }^{1}$

$\left[{ }^{\circ} \mathrm{C}\right.$, degrees Celsius $]$

\begin{tabular}{l|l}
\hline \multicolumn{1}{c|}{ Stream-temperature measurement } & Standard \\
\hline Cold-water aquatic life \\
\hline Instantaneous maximum temperature & $\leq 22^{\circ} \mathrm{C}$ \\
\hline Maximum daily average temperature & $\leq 19^{\circ} \mathrm{C}$ \\
\hline \multicolumn{2}{c}{ Salmonid spawning } \\
\hline Instantaneous maximum temperature & $\leq 13^{\circ} \mathrm{C}$ \\
\hline Maximum daily average temperature & $\leq 9^{\circ} \mathrm{C}$
\end{tabular}

${ }^{1}$ Idaho Administrative Code, Idaho Department of Environmental Quality, IDAPA 58.01.02, p. 139-140, accessed on April 30, 2002: http://www2.state.id.us/adm/adminrules/rules/idapa58/0102.pdf 


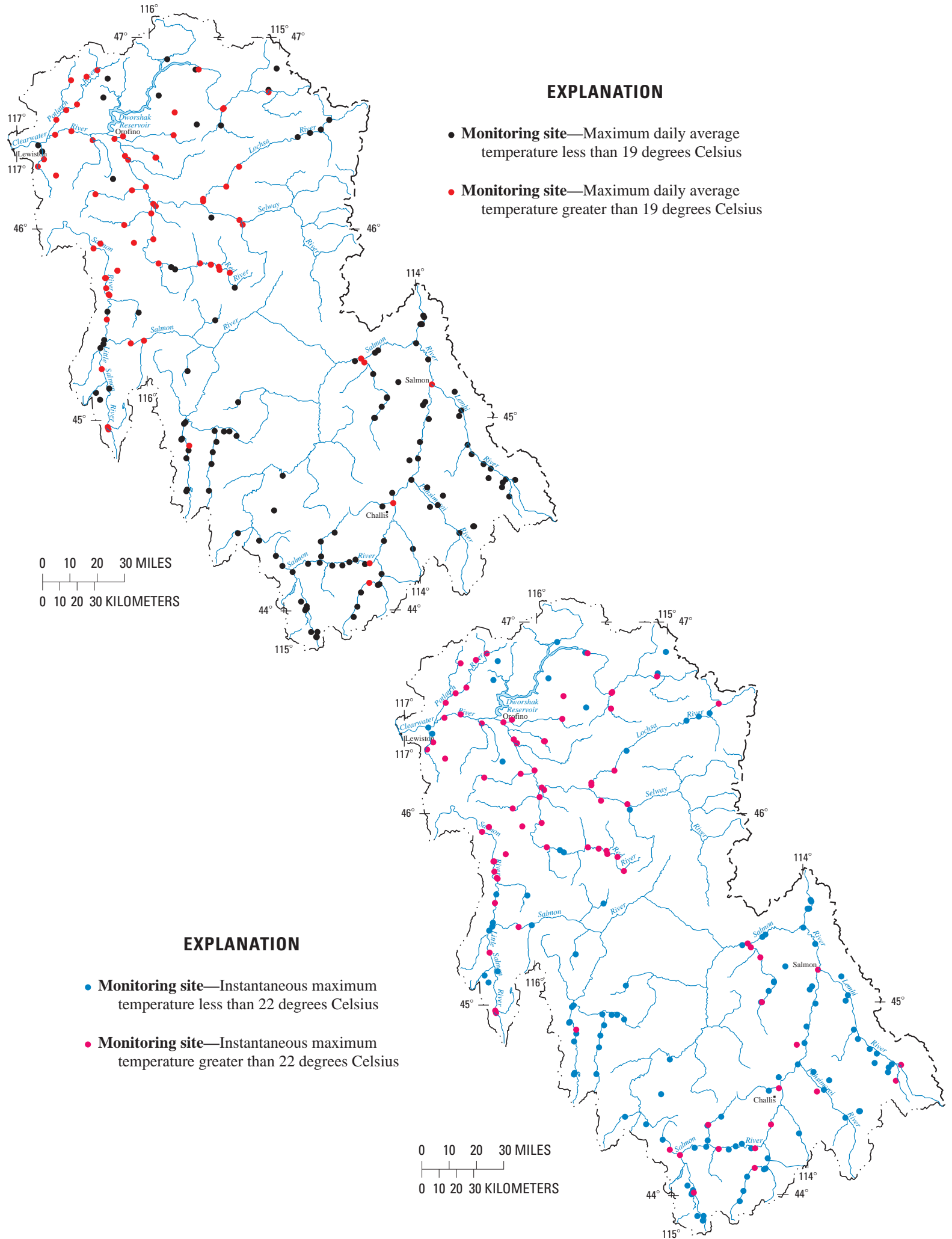

Figure 7. Sites where stream temperatures met or exceeded current Idaho stream-temperature standards for cold-water biota

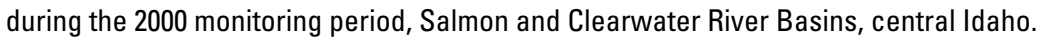


influence, directly or indirectly, the temperature of the stream. Although the modeling approach used for this study was statistical rather than mechanistic, these principles were a useful guide.

Twelve temperature metrics were tested for statistical correlations with more than 20 variables describing the characteristics of the subbasins and sites. Subbasin and site characteristics generally fall into three categories: geographic (for example, elevation and aspect), land cover (vegetation), and climatic (for example, air temperature). Table 6 lists the Spearman correlation coefficients for pairwise comparisons for selected variables. Correlation coefficients in bold are significant at the 95-percent or greater confidence level. The results discussed in the following section reflect observations made for statistical tests performed on all sites as a single group. The data also were analyzed in groups based on stream order (second and third, fourth and fifth, sixth and seventh). Correlations were generally similar to those observed for the single-group method. For second- through fifth-order streams, total drainage area, elevation, and air temperature were the most important variables. For sixth- and seventh-order streams $(n=11)$, elevation and air temperature showed the strongest correlations with monitored stream temperatures.

\section{Geographic Variables}

Elevation, including average subbasin elevation and site elevation, was strongly negatively correlated with stream temperature. Total upstream drainage area was strongly positively correlated with temperature, whereas subbasin area alone was not significantly correlated with temperature. Mean subbasin slope was negatively correlated with temperature. The latter may reflect the fact that surface water in steeper subbasins has shorter residence time to gain heat from its surroundings and, thus, tends to stay cooler. Width and mean depth of the stream at the monitoring site were significantly positively correlated with all temperature metrics except seasonal variation (BIG $\Delta \mathrm{T}$ ). Subbasin aspect, expressed as percentage of subbasin area facing a compass direction (for example, percent southwestfacing), was weakly correlated only with total seasonal variation (table 6). No other metrics were correlated with this variable.

In addition to stream azimuths measured in the field, stream segment azimuths also were derived because they were considered to be a better representation of the general direction of streamflow at a site. Stream segments were assigned a numerical azimuth using a GIS by measuring the azimuth of a vector drawn between a point $600 \mathrm{~m}$ upstream from the temperature site to the site. These values then were converted to a number between -90 and +90 degrees using the method of Bartholow (1989). This method precluded the common problems of analyzing azimuths that range between 0 and 360 degrees. Neither fieldmeasured stream azimuths nor GIS-derived streamsegment azimuths were significantly correlated with any stream-temperature metric. However, results of analysis of stream-segment azimuth expressed as a compass direction (for example, NE, SW) were interesting. Several temperature metrics, including grand average temperature (GAT) and maximum weekly average temperature (MWAT) were significantly higher ( $p<0.05$ ) for northwest- and southwest-flowing stream segments than for southeast- and northeast-flowing segments. There was no significant difference in temperature, however, between northeast- and northwest-flowing versus southeast- and southwest-flowing segments. This may reflect stream warming by solar radiation when the sun shines from the west during the afternoon and early evening, when stream temperatures reach their daily maxima.

\section{Vegetation Variables}

Correlations between vegetation characteristics derived from GIS coverages and stream temperature were variable (table 6). In general, when expressed as a percentage of the entire subbasin area, vegetation and stream-temperature correlations can be explained by vegetation providing shade to reduce solar warming. For example, forested area and wetland were significantly negatively correlated with stream temperature; grassland and barren land were significantly positively correlated with stream temperature. However, these relationships may be a stronger indication of differences in elevation rather than vegetation, because grassland and barren land are at lower elevations, whereas forested lands are chiefly at higher elevations in the study area. Land-cover data were buffered by using a GIS to look at only a 100-m-wide zone on either side of the stream. Buffered land-cover data yielded significant positive correlations between most temperature metrics and percent barren land, grassland, 
Table 6. Spearman correlation coefficients describing correlation of subbasin or site characteristics with stream-temperature metrics for 183 monitored sites used in the statistical model, Salmon and Clearwater River Basins, central Idaho

DRAINAREA, sum of all upstream subbasin areas, in square kilometers $\left(\mathrm{km}^{2}\right)$; MSLOPE, average subbasin slope, in percent; SOUTH, subbasin area facing south, as a percentage of total subbasin area; SWEST, subbasin area facing southwest, as a percentage of total subbasin area; SUMSSW, sum of subbasin areas facing south and southwest, as a percentage of total subbasin area; SITEELEV, site elevation, in meters above sea level; MEANELEV, average subbasin elevation, in meters above sea level; AREASQKM, subbasin area in km²; SEGAZIMUTH, stream-segment azimuth, in degrees; NLCD, National Land Cover Data; FOREST (NLCD), forest of all types, as a percentage of total subbasin area; DECIDFOR (NLCD), deciduous forest, as a percentage of total subbasin area;

EVERGRFOR (NLCD), evergreen forest, as a percentage of total subbasin area; WETLAND (NLCD), wetland, as a percentage of total subbasin area; EMERGWET (NLCD), emergent wetland, as a percentage of total subbasin area; BARREN (NLCD), barren land, as a percentage of total subbasin area; GRASS (NLCD), grassland, as a percentage of total subbasin area; OPENCAN, open canopy angle; RCC, riparian canopy cover, as a percentage; AUGTEMPC, mean August temperature, in degrees Celsius $\left({ }^{\circ} \mathrm{C}\right)$; WIDTHFT, mean stream width, in feet; MDEPTHFT, mean depth, in feet; MDMT, maximum daily maximum temperature; MDAT, maximum daily average temperature; MDNT, maximum daily minimum temperature; MWMT, maximum weekly maximum temperature; MWAT, maximum weekly average temperature; MAX $\Delta \mathrm{T}$, maximum diurnal variation; $\mathrm{BIG} \Delta \mathrm{T}$, total range in observed temperature; GAT, average of all temperature measurements; CONSEC13, maximum number of consecutive hours temperature exceeded $13^{\circ} \mathrm{C}$; CONSEC22, maximum number of consecutive hours temperature exceeded $22^{\circ} \mathrm{C}$; HOURS13, number of hours temperature exceeded $13^{\circ} \mathrm{C}$ HOURS22, number of hours temperature exceeded $22^{\circ} \mathrm{C} ; \mathrm{G}$, geographic; V, vegetation; $\mathrm{C}$, climate; $\mathrm{S}$, site. Correlation coefficients in bold are significant at the 95 -percent confidence level.

\begin{tabular}{|c|c|c|c|c|c|c|c|c|c|c|c|c|c|}
\hline \multirow[b]{2}{*}{ Characteristic } & \multirow[b]{2}{*}{$\begin{array}{c}\text { Characteristic } \\
\text { type }\end{array}$} & \multicolumn{12}{|c|}{ Stream-temperature metric } \\
\hline & & MDMT & MDAT & MDNT & MWMT & MWAT & MAX $\Delta T$ & BIG $\Delta \mathrm{T}$ & GAT & $\begin{array}{c}\text { CONSEC } \\
13\end{array}$ & $\begin{array}{c}\text { CONSEC } \\
22 \\
\end{array}$ & $\begin{array}{c}\text { HOURS } \\
13 \\
\end{array}$ & HOURS22 \\
\hline DRAINAREA & $\mathrm{G}$ & 0.541 & 0.556 & 0.505 & 0.546 & 0.544 & 0.019 & 0.236 & 0.579 & 0.516 & 0.458 & 0.596 & 0.432 \\
\hline MSLOPE & $\mathrm{G}$ & -0.432 & -0.332 & -0.259 & -0.416 & -0.311 & -0.413 & -0.489 & -0.309 & -0.204 & -0.287 & -0.265 & -0.344 \\
\hline$\underline{\text { SOUTH }}$ & $\mathrm{G}$ & 0.063 & 0.082 & 0.08 & 0.067 & 0.094 & -0.015 & 0.007 & 0.08 & 0.081 & 0.106 & 0.053 & 0.105 \\
\hline SWEST & $\mathrm{G}$ & -0.048 & -0.007 & 0.018 & -0.04 & 0.011 & -0.129 & -0.166 & 0.014 & 0.018 & 0.06 & 0.001 & 0.052 \\
\hline SUMSSW & $\mathrm{G}$ & -0.021 & 0.013 & 0.029 & -0.011 & 0.026 & -0.105 & -0.17 & 0.036 & 0.043 & 0.076 & 0.021 & 0.076 \\
\hline SITEELEV & $\mathrm{G}$ & -0.602 & -0.759 & -0.809 & -0.636 & -0.777 & 0.321 & 0.001 & -0.774 & -0.814 & -0.646 & -0.762 & -0.65 \\
\hline MEANELEV & $\mathrm{G}$ & -0.539 & -0.644 & -0.671 & -0.565 & -0.661 & 0.138 & -0.132 & -0.627 & -0.656 & -0.536 & -0.59 & -0.572 \\
\hline AREASQKM & $\mathrm{G}$ & 0.032 & -0.043 & -0.09 & 0.018 & -0.049 & 0.21 & 0.165 & -0.058 & -0.091 & 0.03 & -0.077 & 0.036 \\
\hline$\underline{\text { SEGAZIMUTH }}$ & $\mathrm{G}$ & -0.09 & -0.102 & -0.095 & -0.091 & -0.103 & 0.049 & -0.016 & -0.101 & -0.108 & -0.063 & -0.093 & -0.056 \\
\hline FOREST(NLCD) & $\mathrm{V}$ & -0.202 & -0.186 & -0.156 & -0.218 & -0.174 & -0.131 & 0.009 & -0.278 & -0.181 & -0.12 & -0.284 & -0.142 \\
\hline DECIDFOR (NLCD) & $\mathrm{V}$ & 0.24 & 0.27 & 0.254 & 0.243 & 0.271 & -0.047 & -0.017 & 0.315 & 0.289 & 0.231 & 0.324 & 0.254 \\
\hline EVERGRFOR (NLCD) & $\mathrm{V}$ & -0.165 & -0.109 & -0.063 & -0.162 & -0.097 & -0.175 & -0.015 & -0.208 & -0.086 & -0.099 & -0.213 & -0.118 \\
\hline WETLAND (NLCD) & $\mathrm{V}$ & -0.255 & -0.368 & -0.434 & -0.282 & -0.387 & 0.248 & 0.009 & -0.326 & -0.399 & -0.344 & -0.314 & -0.353 \\
\hline EMERGWET (NLCD) & $\mathrm{V}$ & -0.275 & -0.384 & -0.445 & -0.301 & -0.403 & 0.238 & -0.008 & -0.343 & -0.418 & -0.354 & -0.333 & -0.362 \\
\hline BARREN (NLCD) & $\mathrm{V}$ & 0.215 & 0.222 & 0.19 & 0.215 & 0.21 & -0.003 & 0.013 & 0.22 & 0.192 & 0.314 & 0.218 & $\mathbf{0 . 3 0 1}$ \\
\hline GRASS (NLCD) & $\mathrm{V}$ & 0.259 & $\mathbf{0 . 3 2 8}$ & 0.36 & 0.281 & 0.343 & -0.139 & 0.015 & $\mathbf{0 . 3 3 3}$ & 0.389 & $\mathbf{0 . 2 9 7}$ & 0.346 & 0.302 \\
\hline OPENCAN & $\mathrm{V}$ & 0.077 & -0.035 & -0.057 & 0.067 & -0.031 & 0.273 & 0.181 & -0.024 & -0.078 & 0.065 & -0.01 & 0.059 \\
\hline$\underline{\mathrm{RCC}}$ & $\mathrm{V}$ & -0.146 & 0.011 & 0.082 & -0.123 & 0.036 & -0.372 & -0.325 & 0.042 & 0.11 & -0.108 & 0.033 & -0.088 \\
\hline AUGTEMPC & $\mathrm{C}$ & 0.587 & 0.705 & $\mathbf{0 . 7 3 3}$ & 0.61 & 0.719 & -0.199 & 0.062 & 0.741 & 0.743 & 0.548 & 0.732 & 0.573 \\
\hline WIDTHFT & $\mathrm{S}$ & 0.293 & 0.356 & 0.344 & 0.308 & 0.356 & -0.146 & 0.066 & 0.348 & 0.341 & 0.314 & 0.359 & 0.274 \\
\hline MDEPTHFT & $\mathrm{S}$ & 0.36 & 0.468 & 0.48 & 0.386 & 0.471 & -0.242 & 0.047 & 0.454 & 0.475 & 0.363 & 0.463 & 0.323 \\
\hline
\end{tabular}


and deciduous forest, consistent with the subbasinwide results. Evergreen forest and emergent wetlands were negatively correlated with temperature. The same ambiguities exist regarding the interactions of elevation and vegetation for these results. Although correlations observed for certain land-cover parameters were statistically significant at the 95-percent confidence level, these correlations were weaker than those observed for air temperature, total drainage area, and elevation.

Vegetation characteristics measured in the field (RCC and OPENCAN) were not significantly correlated with temperature metrics except MAX $\Delta \mathrm{T}$ and $\mathrm{BIG} \Delta \mathrm{T}$ and seasonal variation (OPENCAN was positively correlated; RCC was negatively correlated). Because the temperature of a stream is a function of the cumulative effects of all the upstream factors, the riparian vegetation cover at a particular point may not be as important as the riparian vegetation cover throughout the upstream drainage area.

\section{Climate Variables}

Air temperature, expressed as the average August temperature at the measurement site (AUGTEMPC) was significantly positively correlated with all streamtemperature metrics except BIG $\Delta \mathrm{T}$. It should be noted that air temperature, elevation, and vegetation are related variables, and it is difficult to separate the effects of one from the other on stream temperature. Air temperature naturally decreases with increasing elevation because of adiabatic cooling. At the same time, higher elevation subbasins in the study area generally are forested, whereas those at lower elevations contain higher percentages of grassland. All three factors affect stream temperature, but they are clearly not independent variables.

\section{STREAM-TEMPERATURE MODEL}

\section{General Approach}

Although linear regression equations that relate stream temperature to subbasin and site characteristics are useful for resource managers in a general way, the element of time improves the usefulness of a statistical model. Dyar and Alhadeff (1997) analyzed nearly 30 years of year-round stream-temperature monitoring data for Georgia streams to develop a temperature model based on periodic functions that replicate annual stream-temperature fluctuations. For this study, linear regression and nonlinear regression were combined to develop a model that takes into account not only subbasin and site characteristics but also Julian day (day of the year) and daily changes in air temperature that affect stream temperature throughout the summer months.

The model allows the daily average temperature to be estimated for each day from July 24 to September 10. The model has three components: 1) terms for estimating the GAT; 2) terms for estimating the temperature variation caused by seasonal fluctuation, as a daily adjustment for deviation from the GAT; and 3 ) terms to adjust for the effect of short-term air-temperature deviations from a 30-year average air temperature on daily stream temperatures.

The data for the final model were organized as a single group; that is, all data were treated in the same way, regardless of stream order. There were two primary reasons why this approach was taken. First, breaking the data into groups based on stream order caused some of the important statistical relations to be weakened because of the small number of sites in some groups (for example, sixth- and seventh-order streams together comprised only 11 sites). Therefore, modeling was more difficult and less effective, particularly for the estimation of the GAT. Second, keeping the model as simple and as usable as possible for resource managers was a priority. The small degree of precision that might have been gained by tailoring the model to specific stream orders probably would have been counteracted by increased difficulty in practical application of the model to real situations. A more detailed discussion of this issue is presented in the section "Model Evaluation."

\section{Grand Average Temperature}

Multiple linear regression (MLR) was used to derive an equation for the GAT as a function of selected site and subbasin characteristics. Statistical correlations described in the section "Statistical Analysis" guided the choice of variables to use in developing the MLR equation. The equation that yielded the best estimate of the GAT included three independent variables: total drainage area, site elevation, and average subbasin slope. A $\log _{10}$ transformation of the total drainage area was used. Although several land-cover variables were significantly correlated with GAT, none improved the 
Table 7. Results of multiple linear regression to estimate grand average temperature for 183 monitored sites used in the statistical model, Salmon and Clearwater River Basins, central Idaho

[Multiple $\mathrm{r}^{2}=0.792 ;<$, less than; $\mathrm{km}^{2}$, square kilometers; m, meters]

\begin{tabular}{l|c|c|c|c}
\hline & Coefficient & $\begin{array}{c}\text { Standard } \\
\text { error }\end{array}$ & $\mathbf{t}$ & $\begin{array}{c}\text { 2-tail } \\
\text { probability } \\
(\alpha=0.05)\end{array}$ \\
\hline Constant & 17.332 & 0.527 & 32.890 & $<0.001$ \\
\hline $\begin{array}{c}\text { Log }_{(10)} \text { total } \\
\text { drainage } \\
\text { area }\left(\mathrm{km}^{2}\right)\end{array}$ & 1.648 & 0.156 & 10.548 & $<0.001$ \\
\hline $\begin{array}{c}\text { Mean subba- } \\
\text { sin slope } \\
\text { (percent) }\end{array}$ & -0.059 & 0.010 & -5.696 & $<0.001$ \\
\hline $\begin{array}{c}\text { Site } \\
\text { elevation } \\
(\mathrm{m})\end{array}$ & -0.004 & 0.000 & -16.665 & $<0.001$ \\
\hline
\end{tabular}

regression. Table 7 summarizes the statistics for the MLR. The equation for the GAT is:

$$
\begin{array}{r}
\mathrm{GAT}=1.648\left[\log _{10}\left(\text { total drainage area }, \text { in } \mathrm{km}^{2}\right)\right] \\
-[0.059(\mathbf{1}) \\
-[0.004(\text { average subbasin slope }, \text { in percent })] \\
\end{array}
$$

\section{Seasonal Component}

The shapes of the data curves of daily average temperature as a function of time for representative streams during the deployment period are similar, differing mainly in their position on the temperature axis. These data curves indicate a short period of increasing temperature until about August 1, followed by generally decreasing temperatures through the rest of the summer (fig. 3). The similarity of these stream-temperature data curves suggests that the seasonal component of the pattern, that is, the part of the S-shaped annual curve represented by the 58-day deployment period, can be isolated and modeled.

To compare all streams regardless of their absolute temperatures, the data at each site were normalized by subtracting the observed GAT for that site from the daily average temperature for each day of the deployment period. This value, the daily deviation from the GAT at each site, is referred to as $\delta$. The data then were smoothed by using a 20-day moving average to minimize short-term fluctuations and to emphasize the underlying seasonal component of the pattern. Beginning with July 24 , the 20-day moving average was calculated by averaging the value for the previous 9 days, the present day, and the subsequent 10 days; this was repeated for all days. This reduced the total time interval available for consideration and introduced errors at the end of the time interval (no data were available after September 10). The averages for September 1 through September 10 were calculated using 19 through 10 days' worth of data, respectively. The errors introduced by this method for September were considered less critical than they would have been for July and August, when stream-temperature concerns are greatest.

The resulting smoothed curves represent $\delta$ s for sites from July 24 through September 10, a total of 49 days; they describe a segment of the annual streamtemperature fluctuation displayed by all streams in temperate climates.

With few exceptions, the data curves of the normalized, smoothed data for all sites were strongly similar (see fig. 8 for representative streams). Note that most of the daily average temperatures of monitored streams deviated from their own GAT by less than $+4^{\circ} \mathrm{C}$ early in the summer and less than $-6^{\circ} \mathrm{C}$ later in the summer. Most sites reached their average temperature for the measurement period between August 11 and August 17.

Finally, the average $\delta$ of all 183 sites was computed so that each day from July 24 (day 206) through September 10 (day 254) was represented by a single set of values (see section, "General Versus Specific Model," for further discussion). The results were used as the dependent variable in a nonlinear regression routine to generate a periodic function to describe the seasonal variation (after Helsel and Hirsch, 1995, p. 341):

Average deviation $(\mathrm{DAY})=$

$$
\alpha+[\beta \times \sin (0.0172 \times \mathrm{DAY})]
$$

$+[\gamma \times \cos (0.0172 \times \mathrm{DAY})]+(\omega \times 0.0172 \times \mathrm{DAY})$,

where

$$
\begin{aligned}
\text { DAY } & =\text { day of the year, from } 206 \text { to } 254, \\
\alpha & =-460.819, \\
\beta & =77.008, \\
\gamma & =-97.037, \text { and } \\
\omega & =113.835 .
\end{aligned}
$$




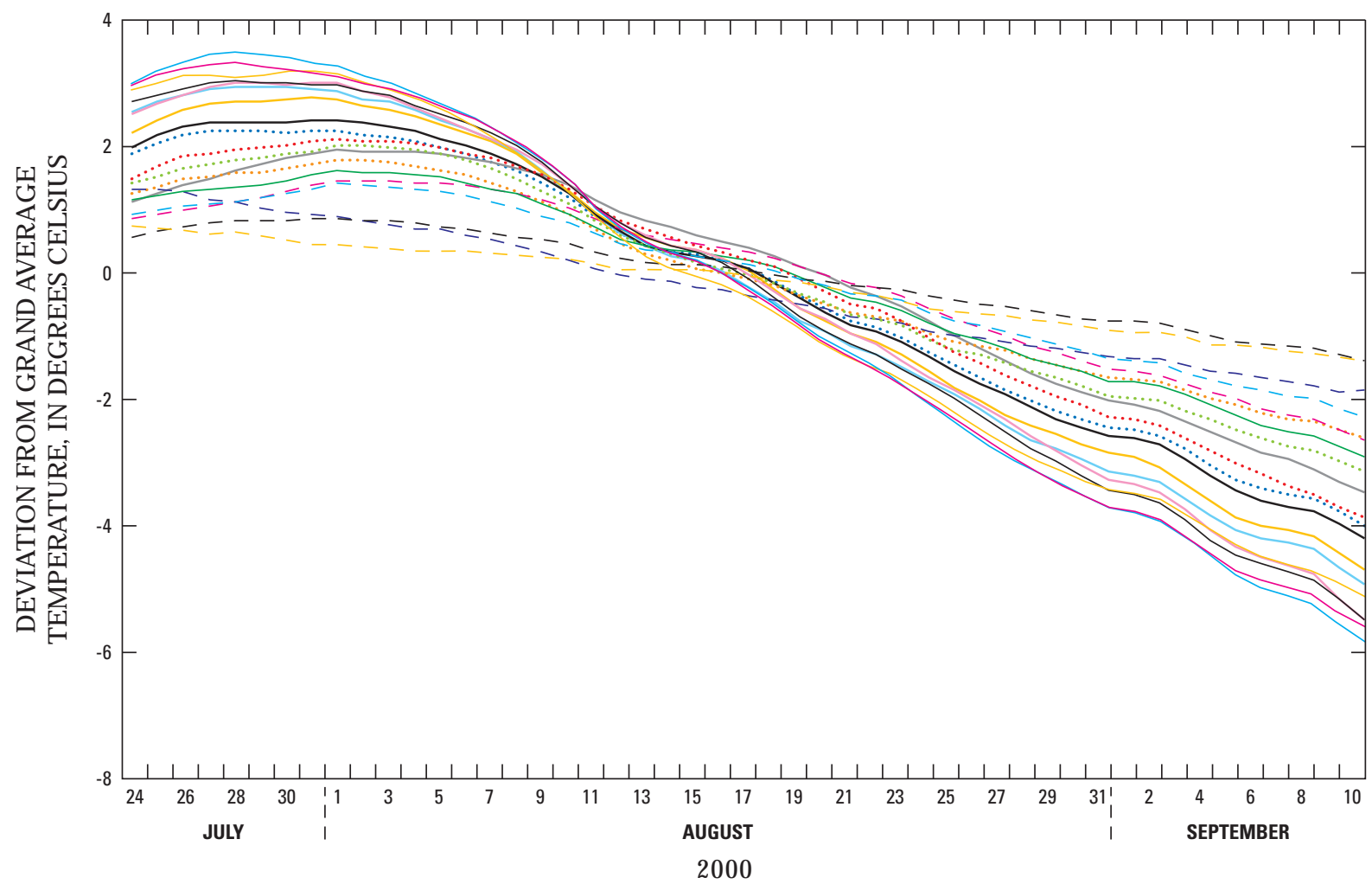

Figure 8. Deviation from grand average temperature for representative streams in the Salmon and Clearwater River Basins, central Idaho. (Patterns used only to differentiate lines)

The mean corrected $\mathrm{r}^{2}$ of the regression was 0.996 , indicating a very good fit between observed and estimated values.

\section{Air-Temperature Adjustment}

The final step in estimating the daily average temperature involved a daily adjustment for short-term airtemperature fluctuations. If this adjustment had not been made, stream temperatures estimated by the model would have represented only the climate conditions of 2000. Whereas subbasin characteristics do not change from year to year, stream temperatures fluctuate with changes in air temperatures at all timescales from daily to annual and from year to year. As discussed previously, fluctuations in stream temperature were observed to coincide with short-term fluctuations in daily average air temperatures. Therefore, the purpose of this adjustment was to allow the model to take into account the daily deviation (positive or negative) of air temperature from a long-term average air temperature for a specific day, and accordingly add to or subtract from the stream-temperature estimate.

Long-term (30-year) daily average air-temperature data for July 24 through September 10 for 10 weather stations in the study area were compiled from the National Weather Service (fig. 9). Daily average air-temperature data for the same 10 weather stations for the time period July 24, 2000, to September 10, 2000, also were compiled. For each weather station and for each day, a ratio was calculated of the daily average air temperature in 2000 to the long-term daily average air temperature. Therefore, if the daily average air temperature in 2000 exceeded the long-term average, the ratio would be greater than 1 for that day. A ratio of less than 1 indicated that the daily average temperature was lower than the long-term average for that day.

Air-temperature ratios from the 10 weather stations were broadly similar. Temperature fluctuations were stronger at some weather stations than at others 
(for example, the ratios at McCall ranged from 0.3 to 1.6, whereas the ratios at Salmon ranged only from 0.7 to 1.2). Nevertheless, the overall similarity in data from the 10 stations suggests that regional air-temperature patterns were fairly uniform, regardless of the location of the station.

The residual (the difference between the unadjusted estimated temperature and the observed temperature for each day) was computed for each stream site. The average daily residual for all sites was calculated and used as the dependent variable in 10 simple linear regressions, one for each of the 10 weather stations. The daily air-temperature ratio was multiplied by 10 for convenience. The regression fit was better for some weather stations than for others, but the results of these regressions were generally similar (table 8).

The regression from the Pierce, Idaho, weather station (the station with the best regression statistics and with complete temperature records for 2000) was used in the final model:

Daily air-temperature adjustment $\left({ }^{\circ} \mathrm{C}\right)=$

$0.299 \times$ (daily air-temperature ratio x 10) - 2.349

Results of regressions based on data from the other weather stations also were acceptable; approximately the same daily adjustments were made using data from the other stations. The maximum upward correction was approximately $2^{\circ} \mathrm{C}$; the maximum downward correction was approximately $1^{\circ} \mathrm{C}$. No time lag between air-temperature changes and stream-temperature changes was used.

This technique of adjusting the estimated stream temperature was reasonably effective for days in which the air temperature did not deviate greatly from the 30year average. However, the model still underestimated stream temperatures for very warm days in spite of the adjustment. This shortcoming is discussed further in the following section. Nevertheless, the improvement in matching estimated and observed temperatures indicated that this component should be included in the final model.

Combining and simplifying terms gives the final, simplified expression for the daily average temperature:
Temperature $_{(\mathrm{DAY})}=$

$1.648\left[\log _{10}\right.$ (total drainage area, in $\left.\left.\mathrm{km}^{2}\right)\right]$

- [0.059 (average subbasin slope, in percent)]

- [0.004 (site elevation, in $\mathrm{m})]$

$+[77.008 \times \operatorname{SIN}(0.0172 \times \mathrm{DAY})]$

$-[97.037 \times \operatorname{COS}(0.0172 \times \mathrm{DAY})]$

$+[113.835(0.0172 \times \mathrm{DAY})]$

$+\left[2.99 \mathrm{x}\right.$ air-temperature ratio $\left._{(\mathrm{DAY})}\right]-446.517$

\section{MODEL EVALUATION}

\section{Estimation Errors}

Errors in the final model were evaluated by comparing the observed and estimated daily average temperatures for all the sites used to build the model. The daily errors (the difference between estimated and observed temperatures) were calculated for each site. A positive error indicated that the model estimated higher temperatures than were observed; a negative error indicated that the model underestimated the temperature. Analysis of the errors allowed temperature estimations to be enclosed by a 95-percent confidence interval for each day. The temperature interval that includes 95 percent of the errors ranged from $5^{\circ}$ to $8^{\circ} \mathrm{C}$, depending on

Table 8. Results of simple linear regression for the air-temperature adjustment component of the statistical model, Salmon and Clearwater River Basins, central Idaho

[No., number]

\begin{tabular}{l|c|c|c|c|c}
\hline $\begin{array}{c}\text { Weather } \\
\text { station }\end{array}$ & Constant & Coefficient & $\begin{array}{c}\text { Multiple } \\
\mathbf{r}^{2}\end{array}$ & F-ratio & $\begin{array}{c}\text { No. of } \\
\text { pairs of } \\
\text { data }\end{array}$ \\
\hline Dixie & -1.734 & 0.236 & 0.550 & 56.145 & 48 \\
\hline Grangeville & -2.241 & 0.264 & 0.459 & 39.909 & 49 \\
\hline Lewiston & -2.421 & 0.313 & 0.401 & 31.504 & 49 \\
\hline May & -1.611 & 0.234 & 0.248 & 15.488 & 49 \\
\hline McCall & -1.814 & 0.235 & 0.539 & 54.934 & 49 \\
\hline $\begin{array}{l}\text { Middle Fork } \\
\text { Lodge }\end{array}$ & -3.458 & 0.381 & 0.468 & 41.293 & 49 \\
\hline Pierce & -2.349 & 0.299 & 0.573 & 63.017 & 49 \\
\hline Powell & -3.161 & 0.372 & 0.365 & 22.463 & 41 \\
\hline Salmon & -3.083 & 0.373 & 0.365 & 27.056 & 49 \\
\hline Stanley & -2.791 & 0.333 & 0.486 & 44.479 & 49 \\
\hline
\end{tabular}




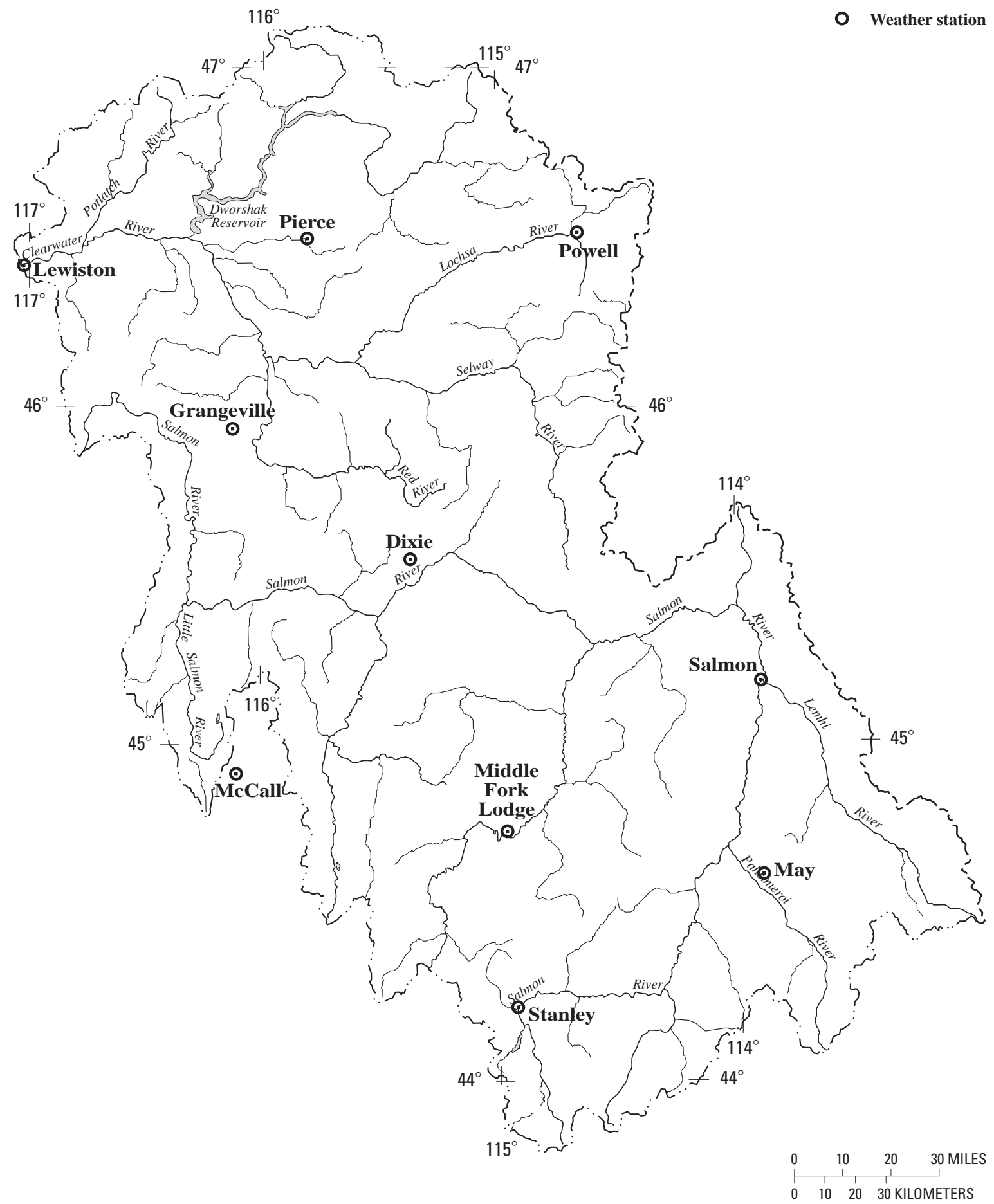

Figure 9. Locations of weather stations that provided air-temperature data used to derive the air-temperature adjustment component of the statistical model, Salmon and Clearwater River Basins, central Idaho. 
the day. The errors are shown graphically in figure 10 .

The mean daily error ranged from approximately $-1.2^{\circ}$ to $+1.1^{\circ} \mathrm{C}$. The largest mean errors occurred in late August and on September 10.

Large negative errors occurred during a severalday period in late August and early September. This coincided with a period of higher-than-normal air temperatures recorded by most of the weather stations. Although the model adjusted temperatures in the correct sense, the correction was insufficient in most cases to account fully for the stream-temperature fluctuations that occurred. The very low streamflows in 2000, particularly in the latter part of the summer, may have contributed to more extreme stream-temperature fluctuations and, hence, larger errors.

The root mean squared error (RMSE), one commonly used measure of goodness-of-fit, is expressed as:

$$
\sqrt{\sum \frac{\left(\mathrm{T}_{\mathrm{e}}-\mathrm{T}_{\mathrm{o}}\right)^{2}}{\mathrm{n}}}
$$

where

$$
\begin{aligned}
\mathrm{T}_{\mathrm{e}}= & \text { temperature estimated by the model, } \\
& \text { in }{ }^{\circ} \mathrm{C} ; \\
\mathrm{T}_{\mathrm{o}}= & \text { observed temperature, in }{ }^{\circ} \mathrm{C} \text {; and } \\
\mathrm{n}= & \text { number of sites. }
\end{aligned}
$$

The RMSE was calculated for each day and ranged from $1.3^{\circ}$ to $2.1^{\circ} \mathrm{C}$. The worst-fit days occurred in late July through early August and at the end of August.

To assess the goodness-of-fit of the model for different-sized streams, the errors were examined by stream-order groups. The mean errors were calculated for second- and third-, fourth- and fifth-, and sixth- and seventh-order streams; the results are shown in figure 11. The errors for sixth- and seventh-order streams were notably different from those of the smaller streams, especially later in the season. Because sixthand seventh-order streams are represented by only 11

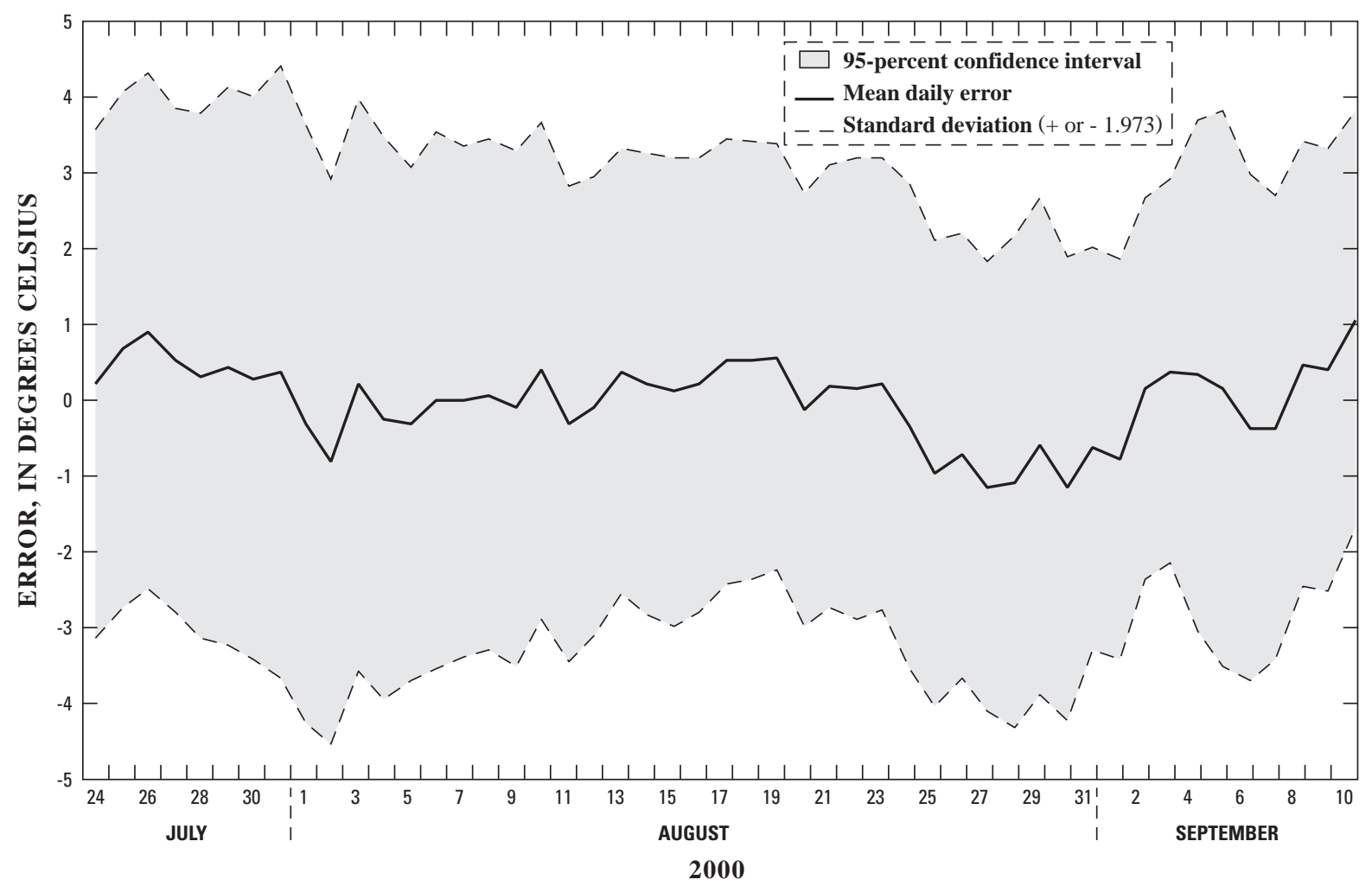

Figure 10. Mean daily stream-temperature error and 95-percent confidence interval for all sites used to develop the statistical model, Salmon and Clearwater River Basins, central Idaho. 
of the 183 sites included in the model, these error differences were apparent only if the errors were examined by stream order. The current model appears to be a better fit for second- through fifth-order streams than for larger streams.

\section{General Versus Specific Models}

In the section, "General Approach," it was stated that the final model was developed by treating the data as a single group (a general model) rather than as separate groups organized by stream order (specific models). The effect of this choice on the accuracy of the model was assessed by deriving specific models for each of the three stream-order groups. Specific regressions for the seasonal and air-temperature components were derived, but the estimates of the GAT remained the same for all streams.

\section{SEASONAL COMPONENT}

As stated earlier in the report, the average $\delta$ of all 183 sites was computed and a single periodic function was derived. This function, however, did not take into account the wide range of seasonal temperature variation observed in the data (fig. 8). To address this issue, second- and third-order, fourth- and fifth-order, and sixth- and seventh-order streams were treated as three separate groups, and three sets of $\delta$ values were computed. Three separate periodic functions based on the average values for each group were derived to test the accuracy of the general model. A graph of these three and the periodic function of the general model as a function of time are shown in figure 12 . The figure shows differences in modeled $\delta$ among the three stream-order groups. The periodic functions for the second- and third-order and fourth- and fifth-order streams closely follow that of the general model, but the periodic function for sixth- and seventh-order streams displays a larger amplitude. The periodic function of

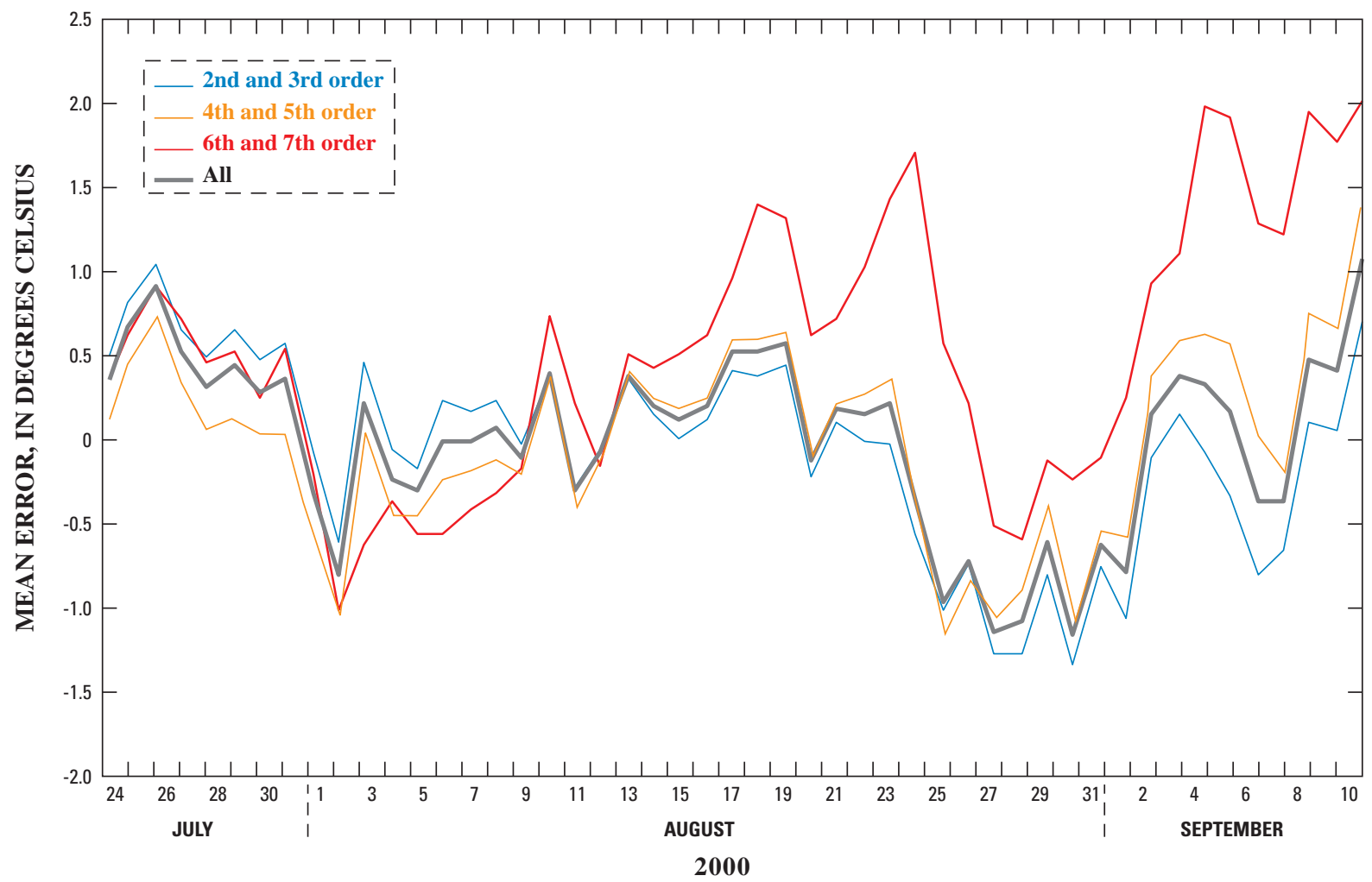

Figure 11. Mean daily stream-temperature error for all sites used to develop the statistical model, calculated by stream-order group, Salmon and Clearwater River Basins, central Idaho. 
the general model underestimated peak summertime temperatures of sixth- and seventh-order streams by about $0.5^{\circ} \mathrm{C}$ and, near the end of the summer, overestimated temperatures for these streams by as much as $0.67^{\circ} \mathrm{C}$, compared with the periodic functions of the specific models.

When the errors for the seasonal component of the general model were analyzed by stream-order groups, those for sixth- and seventh-order streams range from $0^{\circ} \mathrm{C}$ on about August 13 to about $1^{\circ} \mathrm{C}$ on September 10 (fig. 13). By comparison, errors for this component in the specific models showed less variation, did not exceed $0.43^{\circ} \mathrm{C}$, and are generally less than $0.20^{\circ} \mathrm{C}$ (fig. 13). According to this analysis, taking stream order into account in the seasonal component of the model would result in more accurate estimates for sixth- and seventh-order streams.

\section{AIR-TEMPERATURE ADJUSTMENT}

Three separate simple linear regressions, one for each stream-order group, were performed using the same method as that used for the general model described in the section, "Air-Temperature Adjustment." Three daily adjustment regressions, one for each stream-order group, were modeled and the daily adjustments were calculated. The results were compared with those of the single air-temperature adjustment used in the general model. Again, specific models based on stream-order groups produced results that were nearly identical to the results for the general model, except for sixth- and seventh-order streams (fig. 14). For the hottest days, the specific models adjusted the temperature approximately the same amount as the general model, but for the coolest days, the specific models made a stronger downward adjustment.

\section{COMPLETE MODEL}

Finally, the estimation errors for the general model, complete with seasonal and air-temperature adjustments, were compared with errors for the specific models, also complete with both adjustments. Analyzed as a single group, errors for the specific models were essentially identical to those for the general model (fig. 15). For sixth- and seventh-order streams,

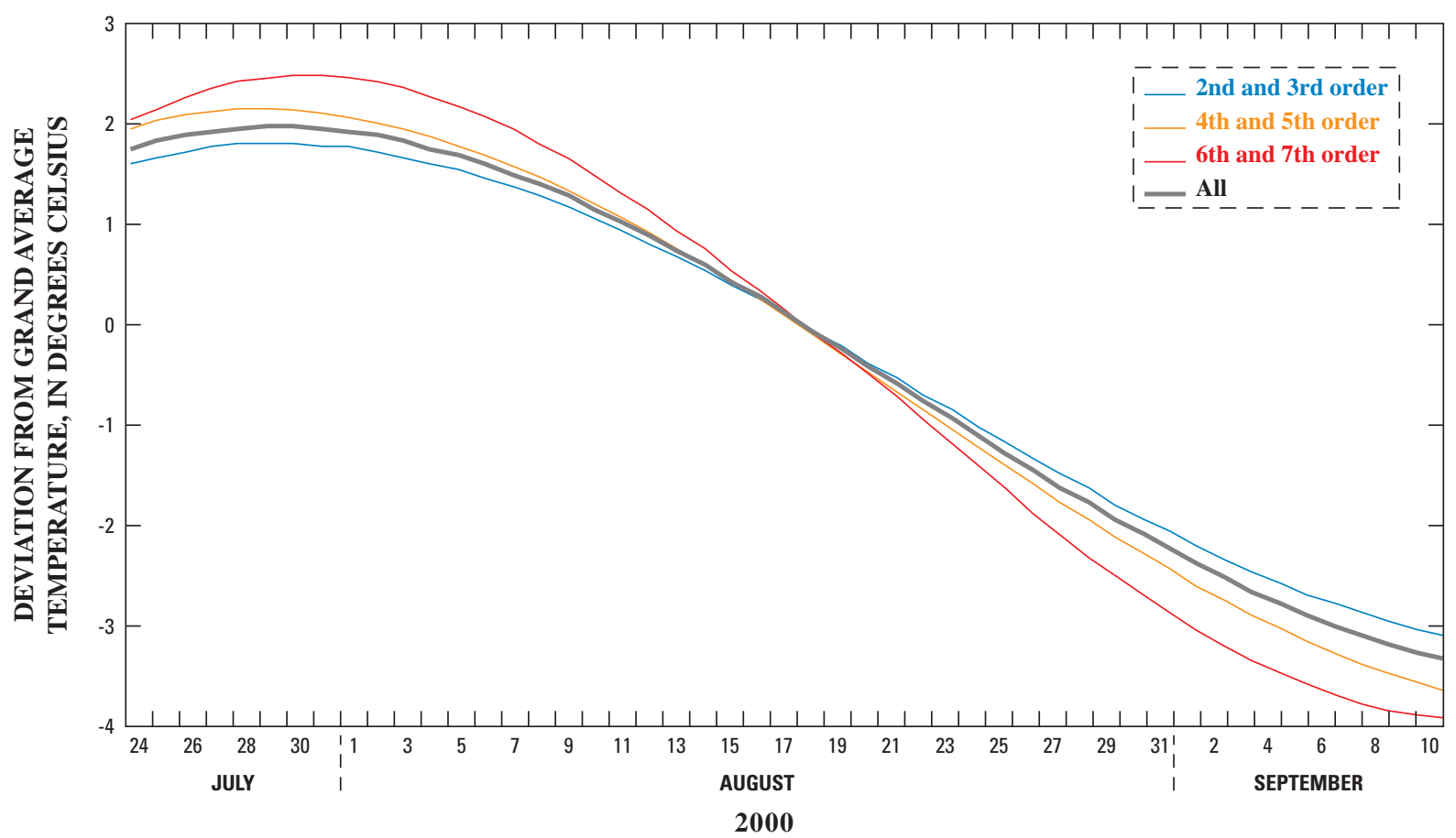

Figure 12. Periodic functions of deviation from grand average temperature for the general model and for three specific models based on stream-order groups, Salmon and Clearwater River Basins, central Idaho. 


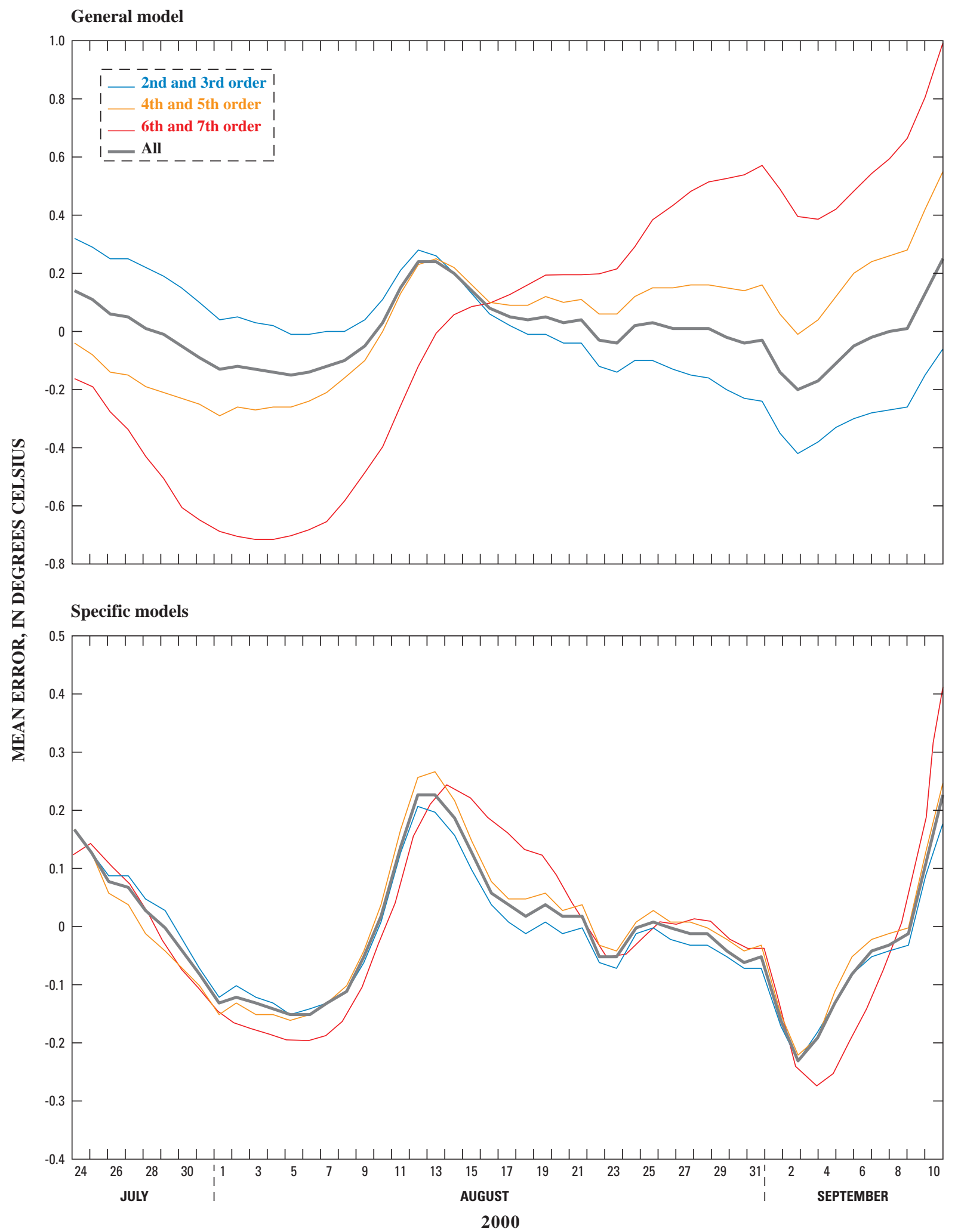

Figure 13. Errors in seasonal component of the general model and three specific models based on stream-order groups, Salmon and Clearwater River Basins, central Idaho. 
errors for the specific models and the general model were similar until approximately August 13 (fig. 15); after that date, the general model estimates higher temperatures than the specific models. The general model performed better than the specific models for times when air temperatures were unusually low (for example, August 28); after that date, errors for the specific models were smaller than those of the general model. Therefore, the complete specific models do not consistently improve the fit of the general model for larger streams.

\section{Independent Tests of the Model}

The model was tested by applying it to 14 sites in the Salmon and Clearwater River Basins for which historical stream-temperature data were available. Estimated temperatures were compared with observed temperatures to test the accuracy of temperature estimates for years other than 2000 and for subbasins not included in the model development data set. Stream discharges in years used for independent tests of the model included high, low, and near average (table 9). Data sources included records of daily average stream temperature from USGS data archives and stream-temperature records supplied by DEQ, U.S. Forest Service, and Bureau of Land Management. Dates of these records ranged from 1970 to 2001 . The location of each test site within its subbasin was determined so that subbasin characteristics necessary for the model calculation (total drainage area, average subbasin slope, and site elevation) could be obtained. Site elevations were determined using a digital elevation model after the site had been located in a GIS. Historical airtemperature data from the Pierce weather station were used when available; data from another nearby weather station were used if Pierce data were unavailable. Selected examples of model tests are described in the following paragraphs.

The model was applied to a site previously monitored by the USGS gaging station 13293800, Salmon

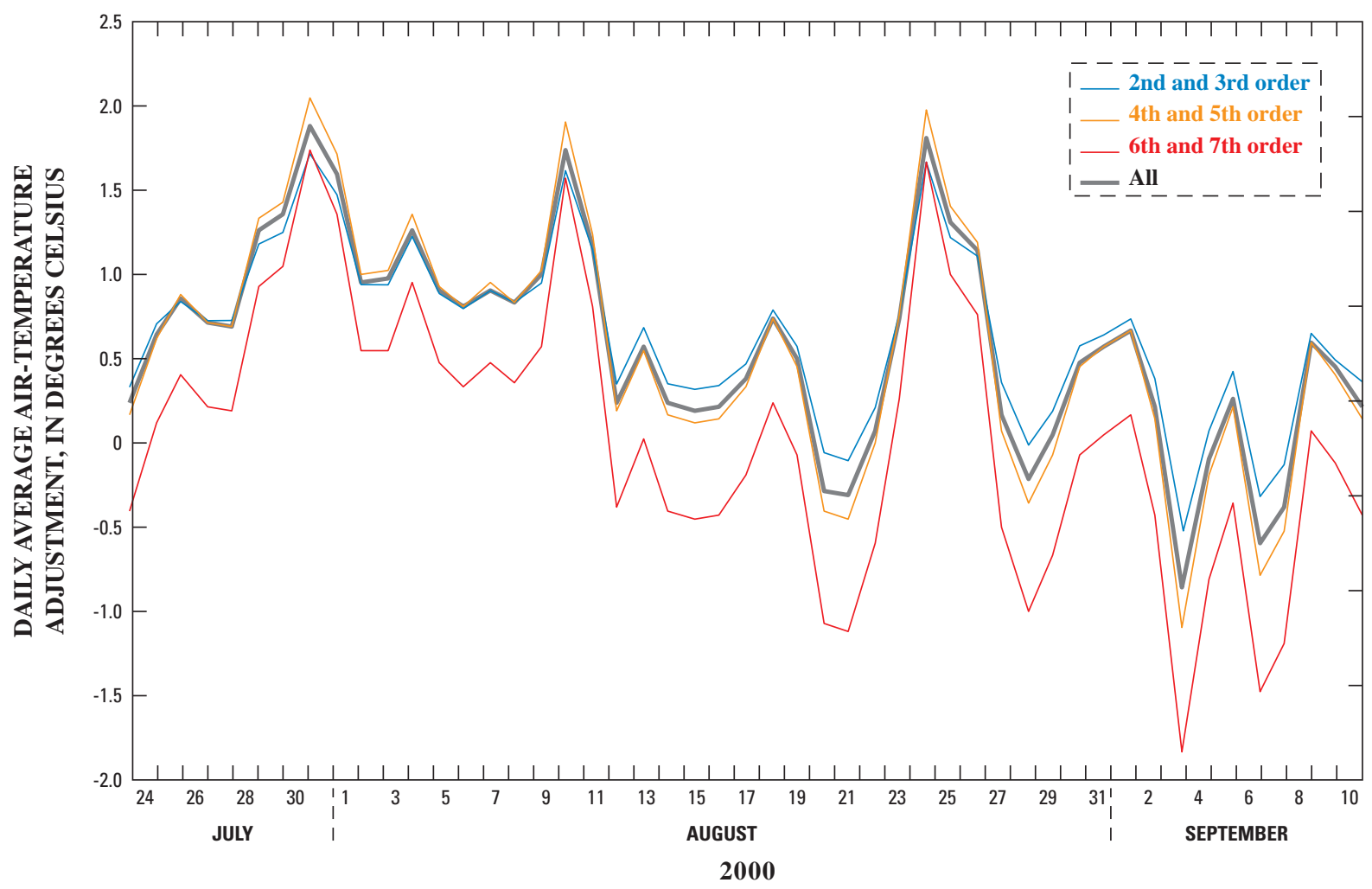

Figure 14. Daily average air-temperature adjustments calculated by the general model and three specific models based on streamorder groups, Salmon and Clearwater River Basins, central Idaho. 


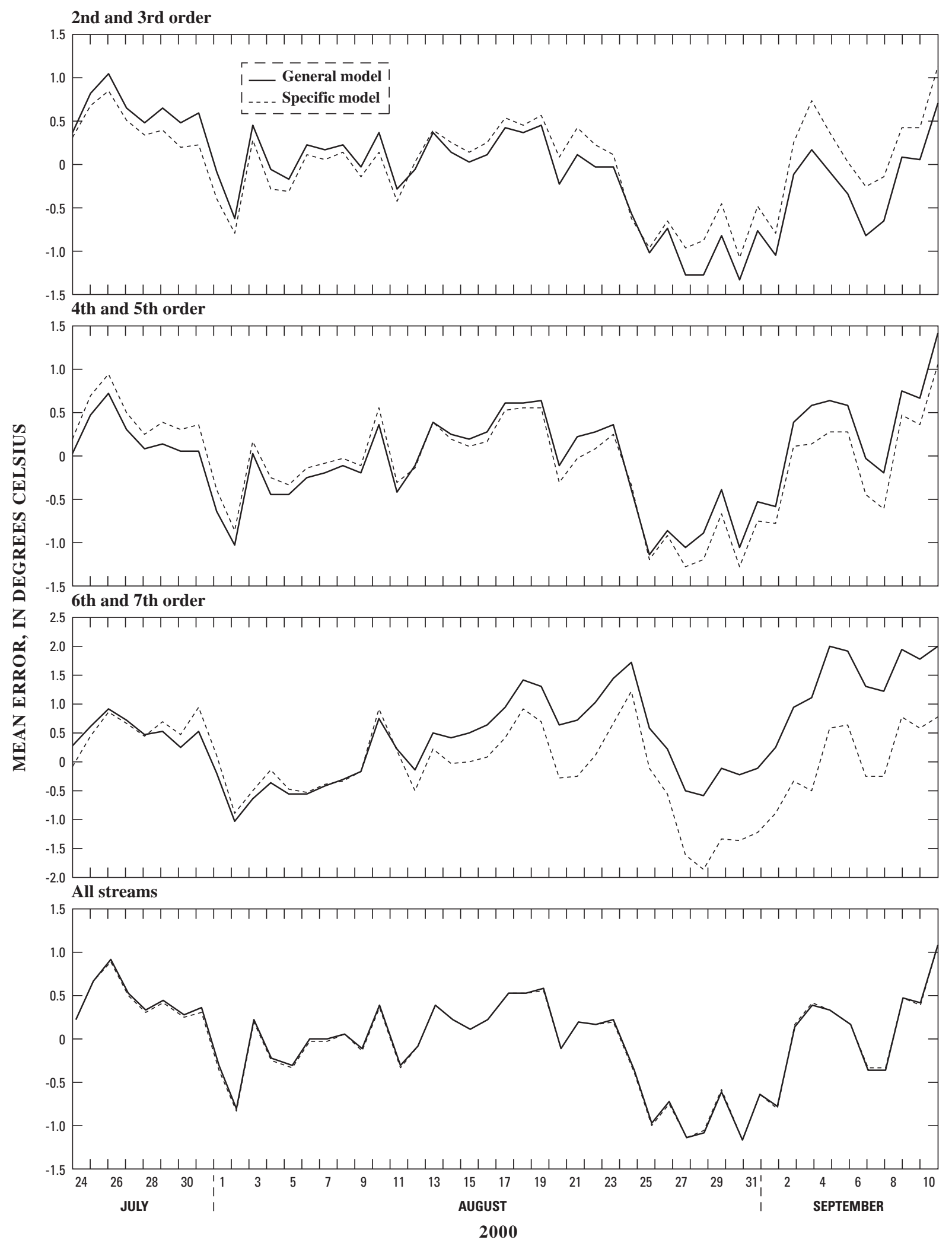

Figure 15. Mean estimation errors for the general model and for three specific models, Salmon and Clearwater River Basins, central Idaho. 
River at Highway 93 above Redfish Lake Creek near Stanley, Idaho. The site is in a subbasin not monitored by the USGS in 2000. The total subbasin drainage area is $793 \mathrm{~km}^{2}$, and the average subbasin slope is 18.7 percent. Stream-temperature records for July 24 through September 10, 1980 and 1982, were compared with temperatures estimated by the model; results are shown in figure 16. For both years, the model estimates the observed daily average temperature within the 95-percent confidence interval. The largest discrepancy between estimated and observed temperatures was $2.9^{\circ} \mathrm{C}$ for 1980 and $3.5^{\circ} \mathrm{C}$ for 1982 . The model generally estimated temperatures accurately for both years, as indicated by the similarity of observed and estimated temperature data curves; however, the model slightly overestimates the early-summer temperatures and underestimates the late-summer temperatures for 1982. The amplitude of the observed temperature data curve for 1982 is small; temperatures varied no more than $3.5^{\circ} \mathrm{C}$ during the entire period. However, the estimated temperature data curve indicates that the temperatures diminished with time.

Observed stream temperatures in the Red River near the Red River Ranger Station (USGS gaging station 13337180, now discontinued) from 1984 and 1986 were compared with stream temperatures estimated by the model (fig. 17). The total subbasin drainage area is $326.8 \mathrm{~km}^{2}$, the average subbasin slope is 14.7 percent, and the site elevation is $1,430 \mathrm{~m}$. The model generally estimated temperatures accurately for both years, as indicated by the similarity of observed and estimated temperature data curves. The maximum difference between observed and estimated temperatures was $2.8^{\circ} \mathrm{C}$.

Observed stream temperatures in Big Deer Creek, also in the Salmon River Basin, for 1999 and 2000 were compared with stream temperatures estimated by the model (fig. 18). The total subbasin drainage area is $120.8 \mathrm{~km}^{2}$, the average subbasin slope is 33.6 percent, and the site elevation is $1,320 \mathrm{~m}$. Observed and estimated daily average temperatures for 1999 and 2000 are compared in figure 18. In 1999, estimated temperatures are up to $5.0^{\circ} \mathrm{C}$ higher than observed temperatures until mid-August, barely within the 95-percent confidence limit. This appears to be related to the generally flat temperature profile exhibited by the stream until late August, when temperatures begin to cool and the model estimates temperatures more closely. Earlysummer stream temperatures for 2000 were more accurately modeled but still exceeded observed temperatures by a maximum of $3.6^{\circ} \mathrm{C}$.

The Lochsa River above Wilderness Gateway Campground was monitored by DEQ in 1998. Complete air-temperature data were not available for the Pierce weather station for 1998 , but temperature estimates made from partial air-temperature data from Pierce and complete data from Grangeville were nearly identical. Consequently, air-temperature data from Grangeville were used for the test shown in figure 19. The total subbasin drainage area is $2,121.1 \mathrm{~km}^{2}$, the

Table 9. Ratio of mean August discharge to long-term average August discharge at selected stream-gaging stations for the year 2000 and for years for which the model was tested, Salmon and Clearwater River Basins, central Idaho

[No., number; R., river; na, not available]

\begin{tabular}{|c|c|c|c|c|c|c|c|c|c|c|c|}
\hline \multirow[b]{2}{*}{ Station No. } & \multirow[b]{2}{*}{ Station name } & \multirow[b]{2}{*}{$\begin{array}{l}\text { Years of } \\
\text { record }\end{array}$} & \multirow[b]{2}{*}{ Basin } & \multicolumn{8}{|c|}{ Ratio of mean August discharge to long-term average August discharge } \\
\hline & & & & 1980 & 1982 & 1984 & 1986 & 1998 & 1999 & 2000 & 2001 \\
\hline 13302500 & $\begin{array}{l}\text { Salmon R. at } \\
\text { Salmon }\end{array}$ & 88 & Salmon & 0.96 & 1.64 & 0.99 & 1.08 & 1.03 & 0.87 & 0.68 & 0.52 \\
\hline 13310700 & $\begin{array}{l}\text { South Fork } \\
\text { Salmon R. near } \\
\text { Krassel Ranger } \\
\text { Station } \\
\end{array}$ & 33 & Salmon & 1.04 & 1.58 & na & 0.90 & 1.19 & 1.24 & 0.70 & 0.48 \\
\hline 13338500 & $\begin{array}{l}\text { South Fork } \\
\text { Clearwater R. } \\
\text { at Stites } \\
\end{array}$ & 39 & Clearwater & 1.10 & 1.43 & 1.19 & 0.86 & 1.11 & 1.10 & 0.50 & 0.75 \\
\hline 13336500 & $\begin{array}{l}\text { Selway R. near } \\
\text { Lowell }\end{array}$ & 74 & Clearwater & 0.98 & 1.47 & 1.19 & 0.76 & 1.09 & 1.25 & 0.68 & 0.78 \\
\hline 13340000 & $\begin{array}{l}\text { Clearwater R. at } \\
\text { Orofino }\end{array}$ & 46 & Clearwater & 1.02 & 1.49 & 1.17 & 0.77 & 1.01 & 1.28 & 0.68 & 0.79 \\
\hline
\end{tabular}




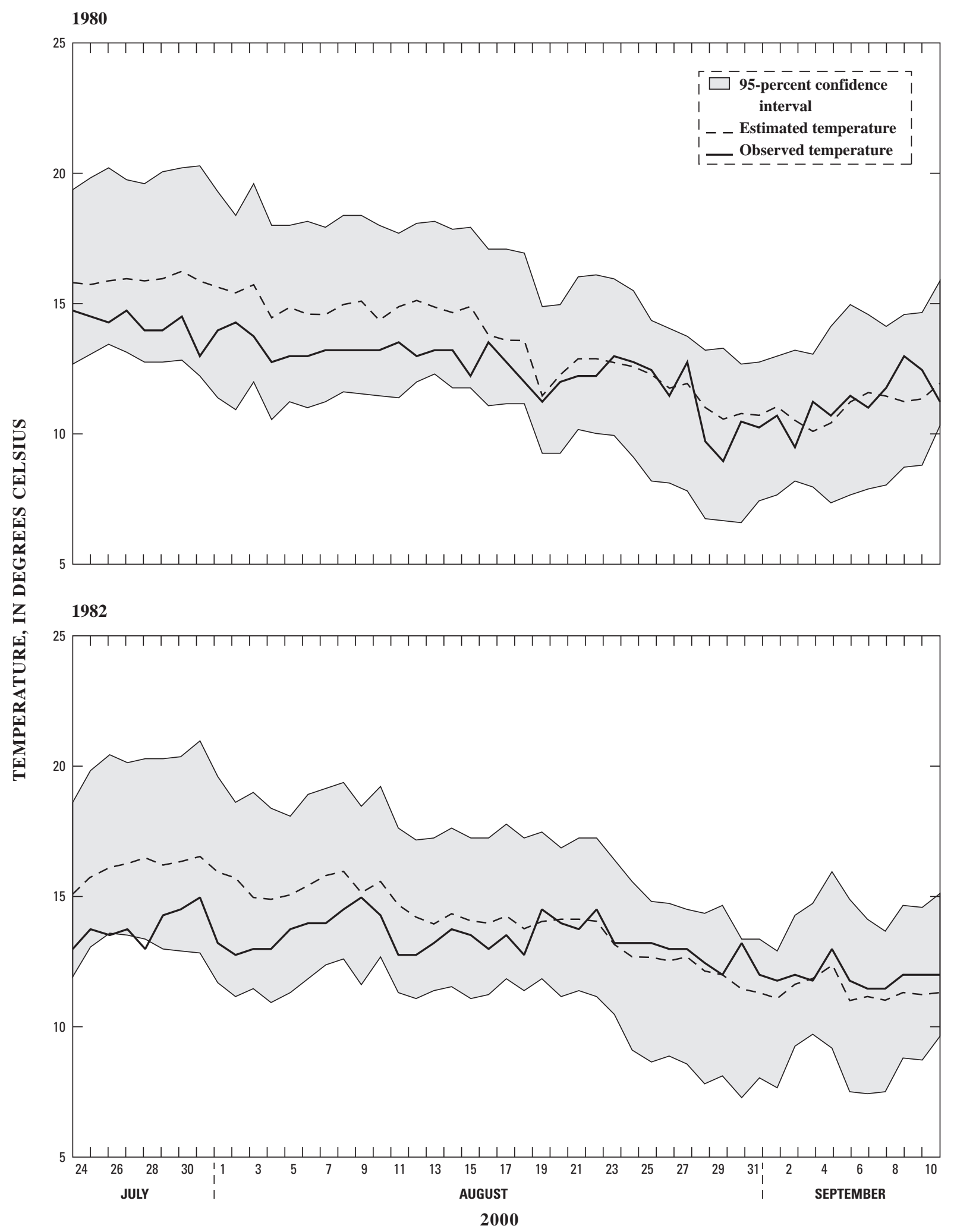

Figure 16. Estimated and observed temperatures of the Salmon River above Redfish Lake Creek (U.S. Geological Survey gaging station 13293800), 1980 and 1982, Salmon River Basin, central Idaho. 


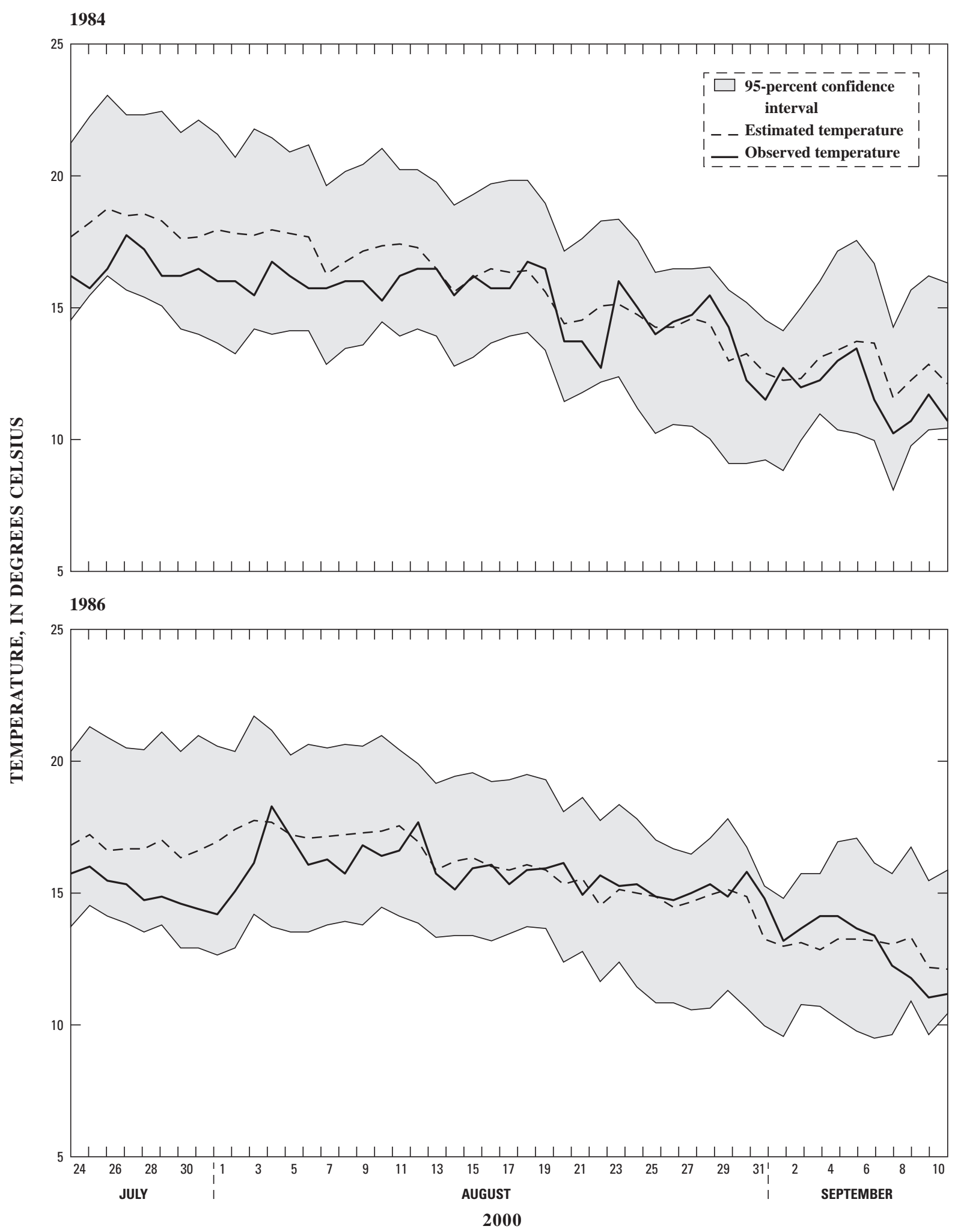

Figure 17. Estimated and observed temperatures of the Red River below South Fork near Red River Ranger Station (U.S. Geological Survey gaging station 13337180), 1984 and 1986, Clearwater River Basin, central Idaho. (Gaging station discontinued in 1988) 
average subbasin slope is 34.9 percent, and the site elevation is $657 \mathrm{~m}$. In this case, the amplitude of the observed temperature curve also was generally small: temperatures did not decrease in late August and early September as the model estimated. Although the model accurately estimated the observed temperatures until early September, it underestimated temperatures during the last several days of the deployment period. This is essentially the same pattern as that in the preceding examples, except that the overall position of the estimated temperature data curve is shifted downward on the temperature axis and, therefore, more closely matches the early-summer observed data curve. Again, the discrepancies are related to lack of curvature of the observed temperature data curve as the summer progresses.

Examples from both large and small streams display this pattern. Wilson Creek, a third-order stream (fig. 20) is representative of most results from DEQ monitoring sites on the Middle Fork of the Salmon River and its tributaries in 2001. The total subbasin drainage area is $99.8 \mathrm{~km}^{2}$, the average subbasin slope is 38.2 percent, and the site elevation is $1,068 \mathrm{~m}$. Complete air-temperature data from Pierce were not available and data from Lewiston were substituted successfully. The model accurately estimates the observed temperatures within $4^{\circ} \mathrm{C}$. Again, the amplitude of the observed stream-temperature data curve is smaller than that of the estimated temperature data curve, but estimates are well within the 95-percent error envelope on most days.

Some of the independent tests have a common characteristic: whereas the model estimates decreasing temperatures throughout the latter part of the summer, observed temperatures generally remained fairly constant (see, for example, fig. 20). The small amplitude of these observed temperature data curves could reflect constant temperatures related to significant inflow from ground water or springs. Alternatively, this could reflect the lack of noticeable cooling later in the summer due to the effects of diminishing streamflows and, hence, uncharacteristically high stream temperatures as the summer progresses. The effects of changes in streamflow on temperature have not been assessed, but this would be a natural next step in refining this temperature model. Whatever the underlying cause, the absence of downward curvature in some observed temperature data curves from years other than 2000 suggests that the part of the model that estimates the seasonal fluctuation in temperature may not be appropriate for all years. This limitation is discussed further in the next section.

\section{Limitations of the Model}

One of the major shortcomings of the model is that it is based on data collected during only one summer, a time of below-average streamflows and aboveaverage air temperatures. Subbasin and site characteristics do not change from year to year, but the seasonal component of the model depends on stream-temperature data that are specific to the year 2000. Streamflows in 2000 were substantially lower than average for the Salmon and Clearwater River Basins at most USGS stream-gaging stations (table 9). Streamflows likely have a strong effect on stream temperatures, but this has not yet been evaluated in a systematic way. The seasonal component of the model, therefore, may not adequately represent conditions as they could occur in another year. This flaw in the seasonal component could account for some of the disagreement of model estimations with observed data from past years, as described in the previous section. Additional temperature-monitoring experiments during years of different streamflows could provide insights that would allow the effects of this variable to be understood.

Air temperature is a factor that is not fully accounted for in the model, and it is not known how warmer or cooler air temperatures will affect the model's overall effectiveness. Mean August air temperatures at Stanley and Grangeville exceeded normal in 2000, but temperatures at McCall, Lewiston, and Salmon were within $1{ }^{\circ} \mathrm{C}$ of normal. Mean August air temperatures for the entire State of Idaho in 2000 ranked as the seventeenth warmest in 107 years of record and were about 4 percent above normal. Because air temperature and stream temperature are strongly related, this is undoubtedly an important issue.

The decision was made to develop a general model based on average values that represented all the data sites as a single group rather than to develop a specific model tailored to stream order. Although this offered the advantage of being simpler, the model is not as well fit for sixth- and seventh-order streams as for the lower order streams, because the sixth- and seventh-order streams represent less than 10 percent of the data. Independent tests of the model for larger streams yielded acceptable results, but users should be aware 


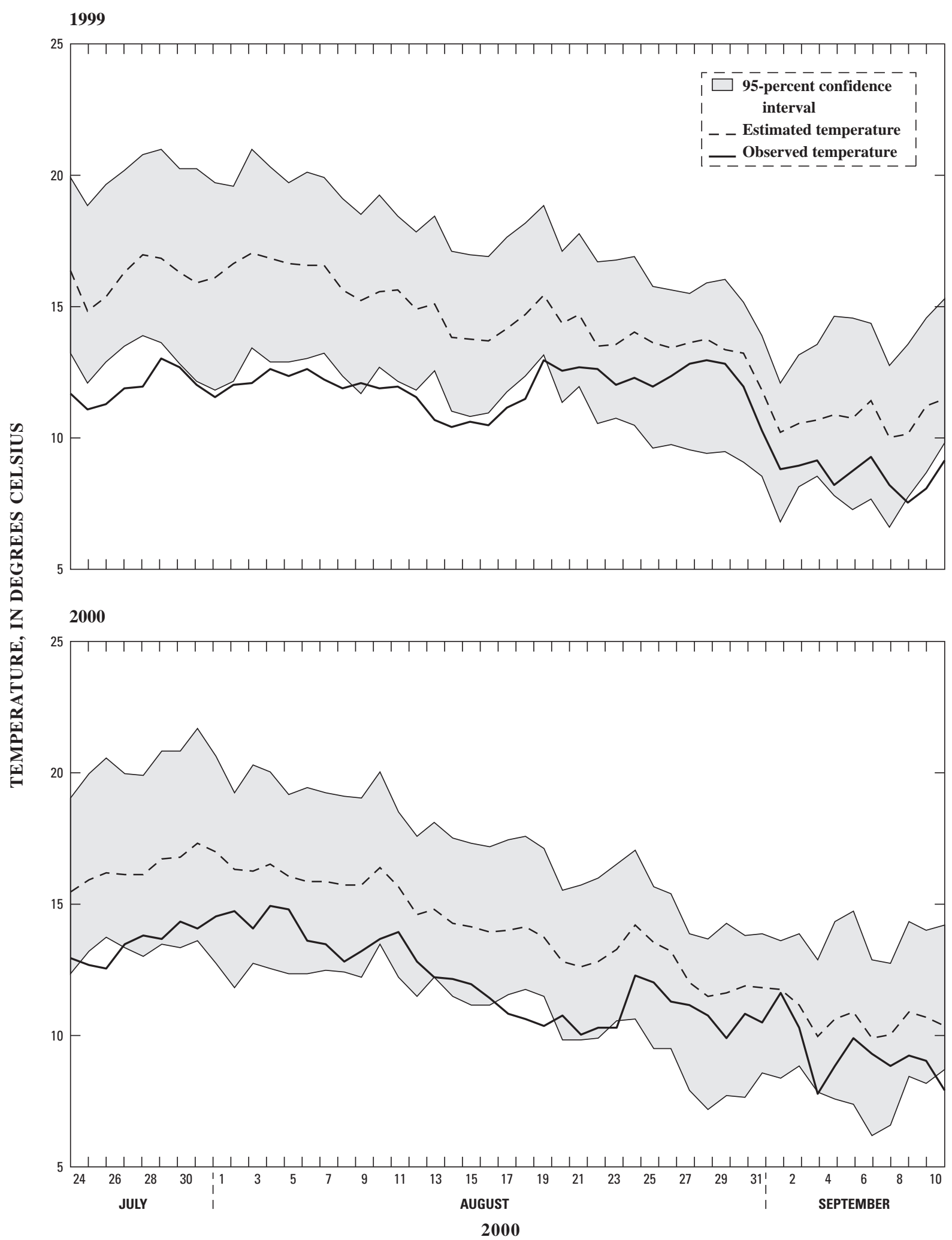

Figure 18. Estimated and observed temperatures of Big Deer Creek, 1999 and 2000, Salmon River Basin, central Idaho. (0 served data from U.S. Forest Service, written communication, 2001) 


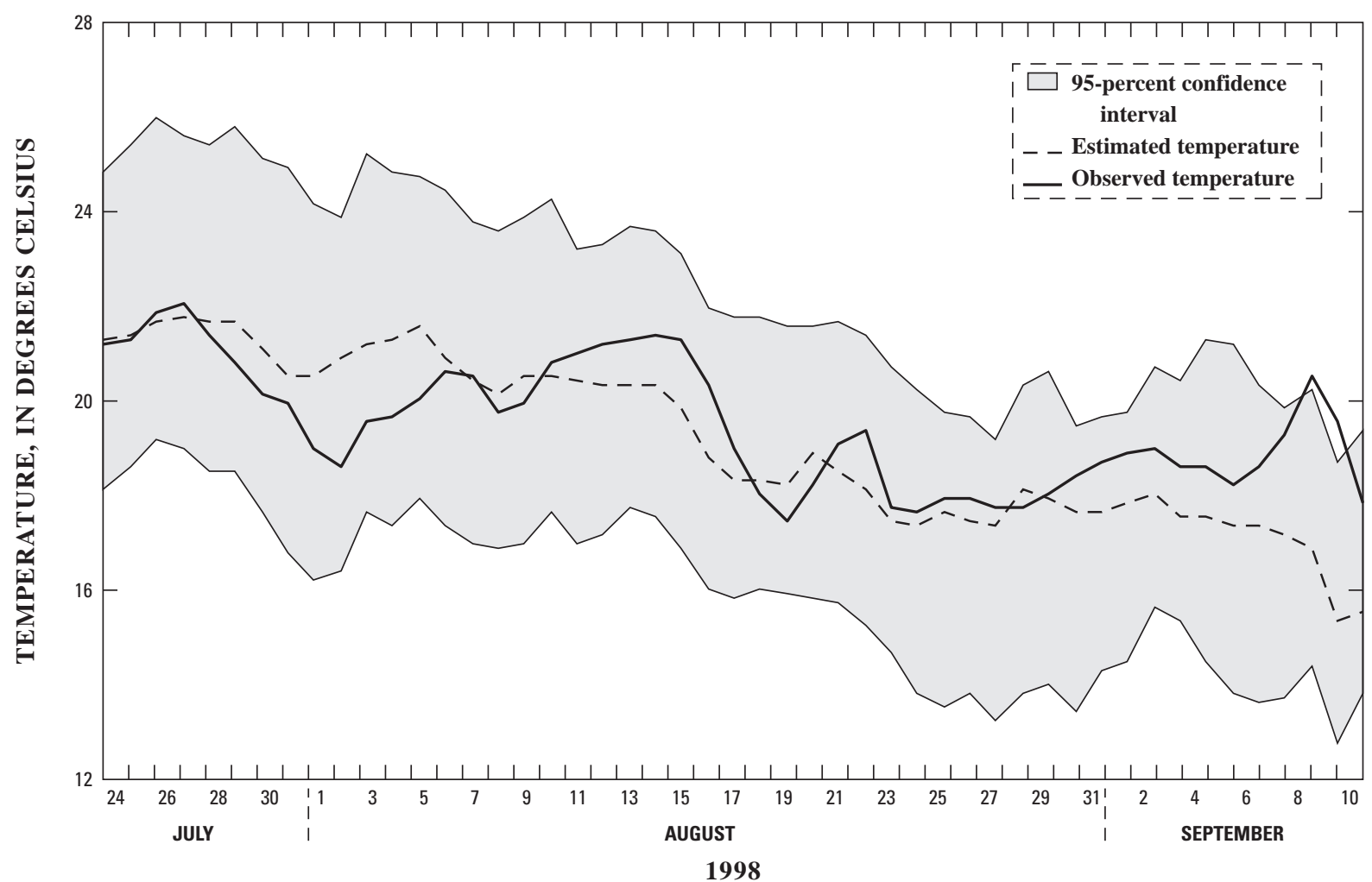

Figure 19. Estimated and observed temperatures of the Lochsa River above Wilderness Gateway Campground, 1998, Clearwater River Basin, central Idaho. (Observed data from Idaho Department of Environmental Quality, written communication, 2001)

that errors in stream-temperature estimates for larger streams were large.

Early tests of the model suggested that it was effective for streams that were free flowing, minimally affected or unaffected by human activities, and unaffected by natural features such as geothermal springs, but the model did not perform well if these conditions were not met. Therefore, the model should not be applied in such areas, or in areas where activities such as disturbance of the streambed, diversion and return of water by irrigation ditches, and removal of riparian vegetation are known to have occurred.

Because the statistical model is based on streamtemperature data from the Salmon and Clearwater River Basins, it should be applied only to streams in that region. However, the methods described in this study could be used to derive a similar model for other regions.

\section{SUMMARY}

Stream temperatures were monitored at more than 200 sites in the Salmon and Clearwater River Basins in central Idaho during the summer of 2000 to provide data to assist DEQ in revising Idaho's stream-temperature standards for protecting cold-water biota and to develop a statistical stream-temperature model.

Temperature results were compared with the current Idaho stream-temperature standards for aquatic life. One-hundred nineteen of the 183 sites used to build the statistical model met the 24-hour maximum daily average temperature standard of $19^{\circ} \mathrm{C} ; 110$ sites met the instantaneous maximum temperature standard of $22^{\circ} \mathrm{C}$. Most of the sites that met the standards are in the Salmon River Basin. None of the monitored sites met the current Idaho temperature standards for salmonid spawning (24-hour maximum daily average temperature, $\leq 9^{\circ} \mathrm{C}$; instantaneous maximum, $\leq 13^{\circ} \mathrm{C}$ ). 


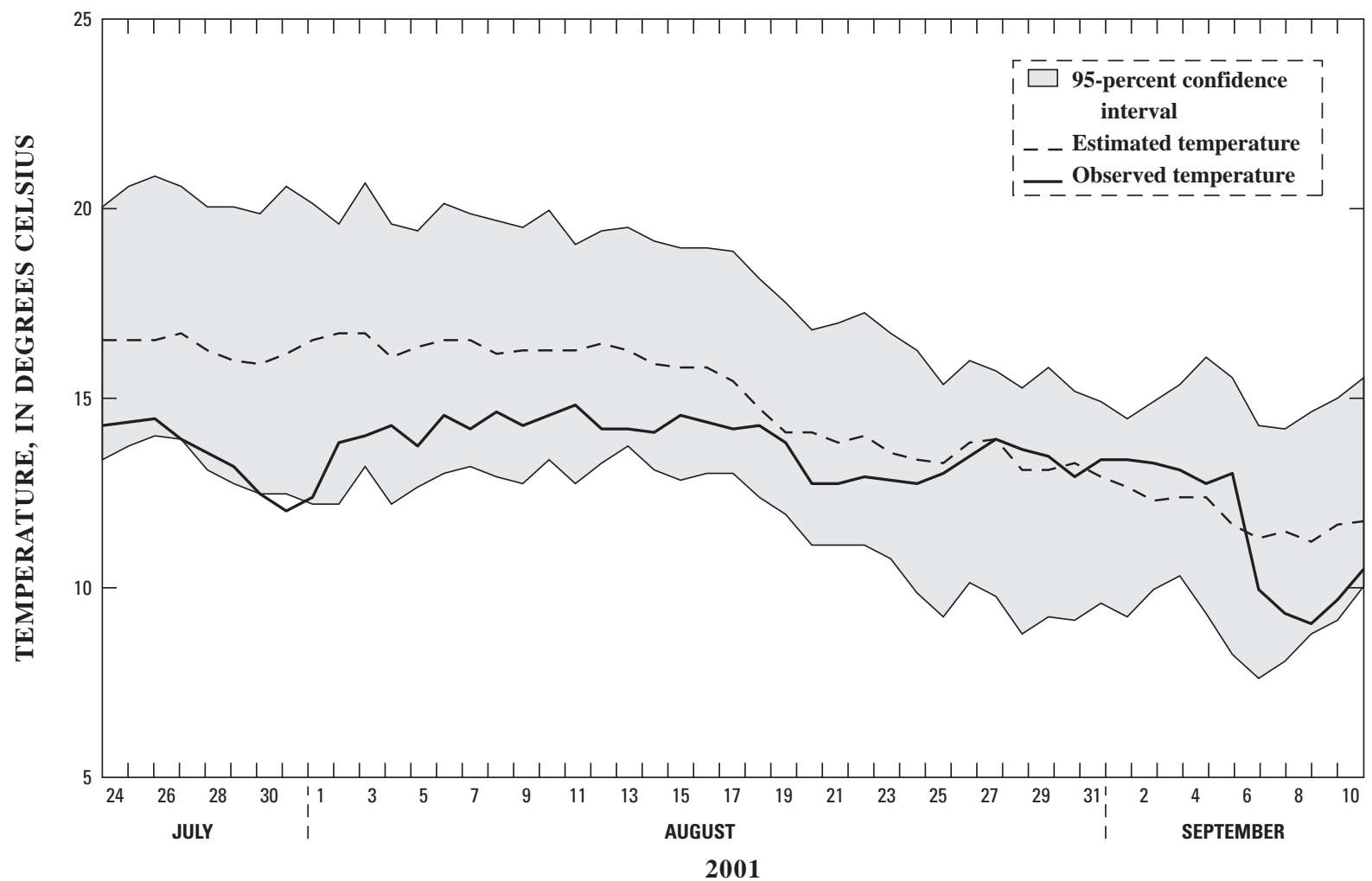

Figure 20. Estimated and observed temperatures of Wilson Creek, 2001, Salmon River Basin, central Idaho. (Observed data from Idaho Department of Environmental Quality, written communication, 2001)

Temperature metrics were calculated from the monitoring data and statistical tests were performed to determine correlations between temperature and a variety of subbasin and site characteristics. Total drainage area, average subbasin slope, site elevation, average subbasin elevation, air temperature, stream width and mean depth, and several subbasin-scale vegetation characteristics were significantly correlated with stream temperature. Subbasin aspect and stream-segment azimuth were not significantly correlated with stream temperature. Riparian canopy cover and open canopy angle (vegetation characteristics measured in the field) were not significantly correlated with stream-temperature metrics except maximum diurnal variation and seasonal variation.

The monitoring data were used to derive a statistical model for estimating daily average stream temperatures between July 24 and September 10 . The model is composed of three parts: 1) an estimation of the grand average temperature, which takes into account total drainage area, average subbasin slope, and site eleva- tion; 2) a seasonal component of the temperature, as a daily adjustment for deviation from the grand average temperature; and 3) a component based on deviation of daily average air temperature from a 30-year average air temperature, which adjusts the stream-temperature estimate to account for short-term air-temperature fluctuations. The model estimated stream temperatures to within $5^{\circ}$ to $8^{\circ} \mathrm{C}$ with 95 -percent confidence. Although the model was based on data representing predominantly second- through fifth-order streams, it also can be applied to sixth- and seventh-order streams, although errors probably will be slightly higher in those cases.

Independent tests of the model were carried out by using it to estimate temperatures for a variety of streams and comparing the results with historical data from Federal and State archives. In general, the model successfully estimated temperatures within the 95-percent confidence interval. In some cases, data curves derived from model-estimated temperatures did not completely match those derived from observed temper- 
atures, a shortcoming that could be a result of groundwater effects or limitations of the model's seasonal component.

A limitation of the model is that it is based on monitoring data from only one summer, during which streamflows were lower than average and air temperatures were higher than average. Additional data from other years would improve the model's general applicability, particularly with regard to the seasonal component. Although the model is intended for use on undisturbed streams in the Salmon and Clearwater River Basins, the methods used to build the model could be used to build a similar model for other regions.

\section{REFERENCES CITED}

Bartholow, John M., 1989, Stream temperature investigations - field and analytical methods: U.S. Fish and Wildlife Service Instream Flow Information Paper no. 13, 139 p.

Dyar, T.R., and Alhadeff, S.J., 1997, Stream-temperature characteristics in Georgia: U.S. Geological Survey Water-Resources Investigations Report 96-4203, 150 p.

Essig, D.A., 1998, The dilemma of applying uniform temperature criteria in a diverse environment- an issue analysis: Idaho Department of Environmental Quality, 29 p., accessed September 15, 2001, at URL

http://www2.state.id.us/deq/water/tempcritpg.htm
Fitzpatrick, F.A., Waite, I.R., D’Arconte, P.J., Meador, M.R., Maupin, M.A., and Gurtz, M.E., 1998, Revised methods for characterizing stream habitat in the National Water-Quality Assessment Program: U.S. Geological Survey Water-Resources Investigations Report 98-4052, 67 p.

Helsel, D.R., and Hirsch, R.M., 1995, Statistical methods in water resources: Amsterdam, Elsevier, Studies in Environmental Science 49, 529 p.

Idaho Administrative Code, Idaho Department of Environmental Quality, IDAPA 58.01.02, p. 139-140, accessed April 30, 2002, at URL

http://www2.state.id.us/admin/adminrules/rules/idapa58/ 0102.pdf

Lipscomb, S.W., 1998, Hydrologic classification and estimation of basin and hydrologic characteristics of subbasins in central Idaho: U.S. Geological Survey Professional Paper 1604, 49 p.

Sullivan, K.J., Tooley, J., Doughty, K., Caldwell, J.E., and Knudsen, P., 1990, Evaluation of prediction models and characterization of stream temperature regimes in Washington: Washington Department of Natural Resources Timber-Fish-Wildlife Report no. TFW-WQ2-90-006, 224 p.

Wehrly, K.E., Wiley, M.J., and Seelbach, P.W., 1997, Landscape-based models that predict July thermal characteristics of lower Michigan rivers: State of Michigan Department of Natural Resources Report no. 2037, 22 p. 


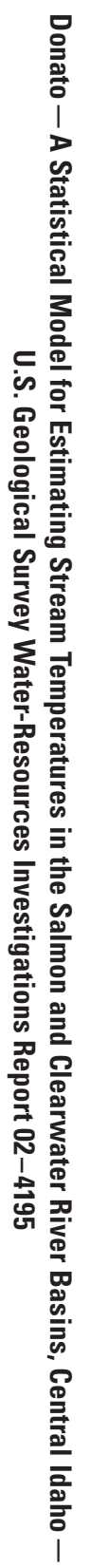

Printed on recycled paper 